\begin{abstract}
UNIVERSIDADE DE SÃO PAULO
ESCOLA DE ENGENHARIA DE SÃO CARLOS

DEPARTAMENTO DE ENGENHARIA DE PRODUÇÃO

PROGRAMA DE PÓS-GRADUAÇÃO EM ENGENHARIA DE PRODUÇÃO
\end{abstract}

SÉRGIO RICARDO GROMIK

\title{
ANÁLISE DAS ATIVIDADES DO DIRIGENTE DA PEQUENA EMPRESA: \\ estudo baseado nos conceitos de Mintzberg sobre o trabalho do administrador
}





\title{
SÉRGIO RICARDO GROMIK
}

\section{ANÁLISE DAS ATIVIDADES DO DIRIGENTE DA PEQUENA EMPRESA: \\ estudo baseado nos conceitos de Mintzberg sobre o trabalho do administrador}

\begin{abstract}
Dissertação apresentada à Escola de Engenharia de São Carlos da Universidade de São Paulo como parte dos requisitos para obtenção do título de Mestre em Engenharia de Produção
\end{abstract}

Área de concentração: Economia, Organizações e Gestão do Conhecimento

Orientador: Prof. Dr. Associado Edmundo Escrivão Filho 
AUTORIZO A REPRODUÇÃO E DIVULGAÇÃO TOTAL OU PARCIAL DESTE TRABALHO, POR QUALQUER MEIO CONVENCIONAL OU ELETRÔNICO, PARA FINS DE ESTUDO E PESQUISA, DESDE QUE CITADA A FONTE.

Ficha catalográfica preparada pela Seção de Tratamento da Informação do Serviço de Biblioteca - EESC/USP

\footnotetext{
Gromik, Sérgio Ricardo

Análise das atividades do dirigente da pequena empresa

: estudo baseado nos conceitos de Mintzberg sobre o

trabalho do administrador. / Sérgio Ricardo Gromik ;

orientador Edmundo Escrivão Filho. São Carlos, 2011.
}

Dissertação (Mestrado - Programa de Pós-Graduação em Engenharia de Produção e Área de Concentração em Economia, Organizações e Gestão do Conhecimento) - Escola de Engenharia de São Carlos da Universidade de São Paulo, 2011.

1. Pequena empresa. 2. Trabalho do administrador. 3. Dirigente da pequena empresa. I. Título. 


\section{FOLHA DE JULGAMENTO}

\section{Candidato: Bacharel SERGIO RICARDO GROMIK}

Título da dissertação: Análise das atividades do dirigente da pequena empresa: estudo baseado nos conceitos de Mintzberg e demais contribuições sobre o trabalho do administrador.

Data da defesa: 07/10/2011:

\section{Comissäo Julgadora:}

Prof. Associado Edmundo Escrivão Filho (Orientador) (Escola de Engenharia de São Carlos/EESC)

Prof. Dr. José Euzébio de Oliveira Souza Aragão

(Universidade Estadual Paulista "Júlio de Mesquita Filho"/UNESP/campus de Rio Claro)

Prof. Dr. Josadak Astorino Marçola

(Universidade Paulista/UNIP/campus de Araraquara)

\section{Resultado:}

Alonolys 0

ApROVADO APROVADO

Coordenador do Programa de Pós-Graduação em Engenharia de Produção:

Prof. Titular Henrique Rozenfeld

Presidente da Comissão de Pós-Graduação:

Prof. Associado Paulo Cesar Lima Segantine 



\section{DEDICATÓRIA}

Aos meus pais, mulher e filhos pela paciência,ajuda e compreensão nos momentos mais críticos do trabalho. Ao professor Edmundo pela amizade, confiança, dignidade, honradez e inspiração. 


\section{AGRADECIMENTOS}

Agradeço a todos que colaboraram para a realização deste trabalho.

Ao Prof. Edmundo Escrivão Filho pela orientação, exemplo de profissionalismo, perseverança e paciência com meus erros e contumaz falta de tempo.

Aos professores do Departamento de Engenharia de Produção da EESC-USP pelo conhecimento transmitido.

Às professoras da Escola de Enfermagem de Ribeirão Preto da Universidade de São Paulo pela oportunidade e conhecimento transmitido.

Aos funcionários do Departamento de Engenharia de Produção pela prontidão na ajuda e orientação.

Aos funcionários da Biblioteca da EESC-USP pelos serviços prestados.

À Universidade de São Paulo pela estrutura proporcionada.

À Caroline Moraes pela enorme ajuda com a tradução para o inglês.

Aos colegas Alexandre, Cintia e Paulo Sérgio, companheiros sempre presentes, pela providencial ajuda com as questões acadêmicas.

Aos colegas do GEOPE pela amizade, orientação, apoio e companheirismo que sempre pude contar em minha jornada.

Aos colegas do SEBRAE/SP, especialmente ao Fernando Chinaglia e Paulo Marcelo, pela confiança, apoio e energia positiva.

Em especial, aos empresários entrevistados que, sem a sua participação e colaboração, esse trabalho seria inviável. 


\section{RESUMO}

GROMIK, S.R. (2011). Análise das atividades do dirigente da pequena empresa: estudo baseado nos conceitos de Mintzberg sobre o trabalho do administrador. 149f. Dissertação (Mestrado) - Escola de Engenharia de São Carlos, Universidade de São Paulo, São Carlos, 2011.

O objetivo geral de investigação é avaliar as coerências e divergências entre a explicação da natureza do trabalho do dirigente da pequena empresa e teorizações de Mintzberg e demais contribuições existentes na literatura administrativa. Como objetivos específicos pretende-se: verificar as características e o conteúdo do trabalho do dirigente da pequena empresa; identificar as semelhanças e diferenças entre os casos múltiplos estudados; e interpretar as possíveis diferenças entre as características do trabalho dos dirigentes. O tema da pesquisa é a natureza do trabalho do administrador e o objeto de análise a pequena empresa. Dada a importância da pequena empresa no contexto social e econômico e o papel determinante do seu dirigente na sua administração, a pesquisa fundamenta-se na lacuna de estudos na literatura que abordem o trabalho do dirigente da pequena empresa. $O$ paradigma investigativo é qualitativo usando como estratégia o estudo de casos múltiplos. Os dados foram coletados por meio de múltiplas fontes de evidências e a análise feita internamente e entre casos cruzados. Na etapa de campo, dois dirigentes de pequenas empresas, selecionados por meio de escolha amostral proposital, foram observados na sua rotina diária por uma semana cada um. Os dados coletados permitiram a análise comparativa com as teorizações selecionadas para trabalho sendo possível concluir que há mais semelhanças nas características do trabalho do dirigente da pequena empresa do que propriamente diferenças. O trabalho teve o propósito de contribuir com estudos organizacionais voltados para o desenvolvimento de uma teoria administrativa para a pequena empresa; o dirigente da pequena empresa que deseja conhecer a teoria sobre o trabalho do administrador; trabalhos acadêmicos visando despertar o interesse em futuras investigações sobre o tema e o objeto de estudo; projetos de consultoria organizacional voltados para pequenas empresas; e trabalhos educacionais de capacitação profissional dos dirigentes da pequena empresa.

Palavras-chave: Trabalho do administrador. Pequena empresa. Dirigente da pequena empresa. 


\begin{abstract}
GROMIK, S.R. (2011). Analysis of the activities of small business managers: a study based on Mintzberg's concepts about managerial work. 149f. Dissertação (Mestrado) Escola de Engenharia de São Carlos, Universidade de São Paulo, São Carlos, 2011.

The main investigative goal is to evaluate the similarities and differences among Mintzberg's theories, the nature of the work performed by the small business manager and the other contributions present in the business administration literature. The specific goals are: to examine the characteristics and the extent of the work performed by small business managers; to identify similarities and differences among the multiple cases studied and to interpret the possible differences of characteristics in the managerial work. The research theme is the nature of managerial work and the object of analysis, small business. Considering the social and economic importance of small businesses and the determinant role of their managers, the work is based on the gaps found in the literature. The investigative paradigm is qualitative and the strategy applied is the multiple case study. Data was collected through multiple sources and analysis was performed internally for each case and across the multiple cases. During field work two small business managers, selected through a deliberate sample choice, were observed in their daily routine for a week each. Data collected was analyzed in comparison with the theories selected for this study and it was possible to conclude that there are more similarities in working styles of small business managers than actual differences. The purpose of the work was to contribute to the organizational studies aimed at developing an administrative theory of small businesses; to help the small business manager who wants to know about administrative theories; to add to the academic production and spark interest in future investigations about the theme and the subject of study; to help in the development of business consulting projects for small business and to contribute with educational projects for the professional development of small business managers.
\end{abstract}

Key words: Administrative work. Small business. Small business manager. 


\section{LISTA DE FIGURAS}

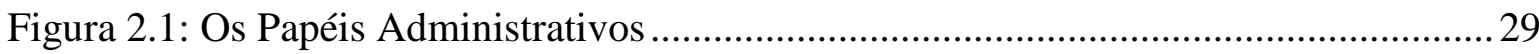

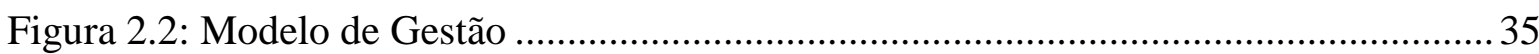

Figura 2.3: Modelo das Demandas, Restrições e Escolhas ................................................ 41

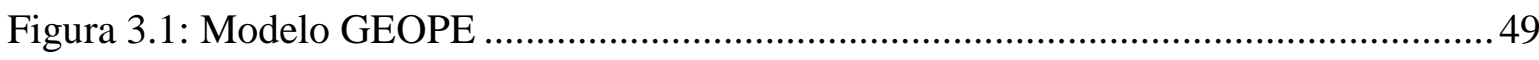

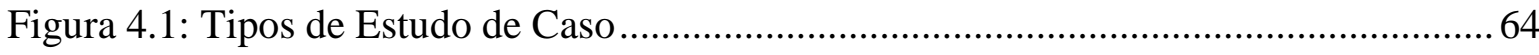




\section{LISTA DE QUADROS}

Quadro 2.1: Papéis Interpessoais: constructos teóricos ..................................................32

Quadro 2.2: Papéis Informacionais: constructos teóricos ....................................................33

Quadro 2.3: Papéis Decisionais: constructos teóricos ............................................................33

Quadro 3.1: Participação das Micro e Pequenas Empresas ...............................................44

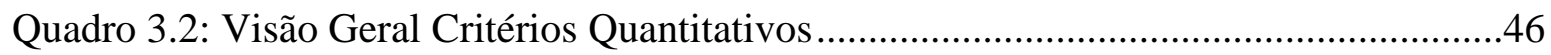

Quadro 3.3: Porte segundo a Receita Bruta Anual ............................................................46

Quadro 3.4: Critérios de Classificação da Pequena Empresa ..............................................47

Quadro 3.5: Visão Geral Critérios Qualitativos de Classificação da Pequena Empresa ......47

Quadro 3.6: Características Micro e Pequenas Empresas - IBGE/SEBRAE .......................48

Quadro 4.1: Tipos, opções, vantagens e limitações da coleta de dados .............................69

Quadro 4.2: Dimensões e categorias das atividades do dirigente ......................................76

Quadro 6.1: Características Comparadas Dirigentes Z e T.............................................111

Quadro 7.1: Resumo Comparativo entre estudos Dirigentes Z e T e

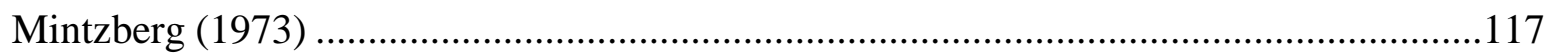

Quadro 7.2: Resumo Comparativo entre estudos Florén e Tell (2006)

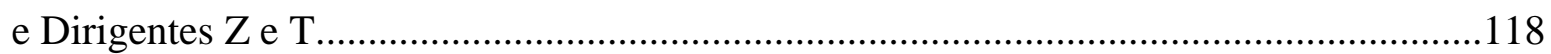

Quadro 8.1: Comparativo estudos Mintzberg, Florén e Tell e Dirigentes Z e T ................126 


\section{LISTA DE TABELAS}

Tabela 6.1: Resumo das Categorias Análise Cronológica Dirigente Z ..............................96

Tabela 6.2: Atividades Mesa de Trabalho Dirigente Z .................................................. 97

Tabela 6.3: Ligações Telefônicas Dirigente Z..................................................................97

Tabela 6.4: Reuniões Agendadas Dirigente Z .............................................................. 97

Tabela 6.5: Reuniões Não Agendadas Dirigente Z ......................................................98

Tabela 6.6: Visita Interna Empresa Dirigente Z ............................................................. 98

Tabela 6.7: Visita Externa Empresa Dirigente Z ............................................................ 99

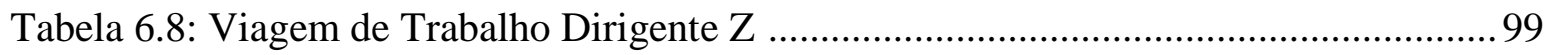

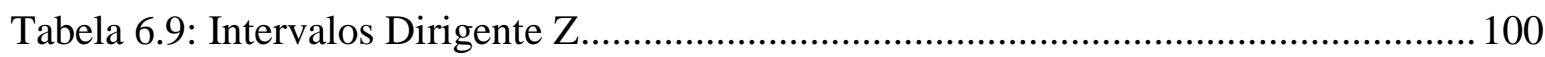

Tabela 6.10: Resumo Contatos Pessoais Dirigente Z ..................................................... 100

Tabela 6.11: Meios de Contato Pessoal Dirigente Z ..................................................... 100

Tabela 6.12: Participantes Contato Pessoal Dirigente Z ................................................ 101

Tabela 6.13: Iniciativa Contato Pessoal Dirigente Z .................................................... 101

Tabela 6.14: Lugar Contato Pessoal Dirigente Z .............................................................. 101

Tabela 6.15: Resumo das Categorias Análise Cronológica Dirigente T ........................... 102

Tabela 6.16: Atividades Mesa de Trabalho Dirigente T ................................................ 102

Tabela 6.17: Ligações Telefônicas Dirigente T............................................................... 103

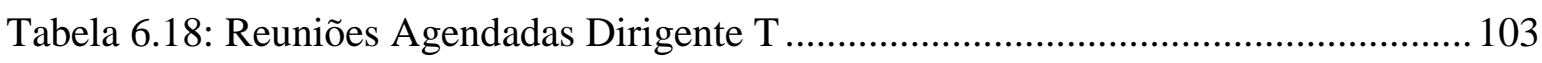

Tabela 6.19: Reuniões Não Agendadas Dirigente T ..................................................... 103

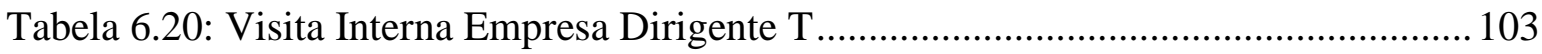

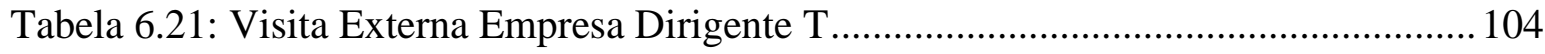

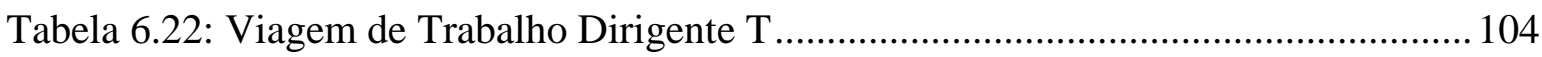

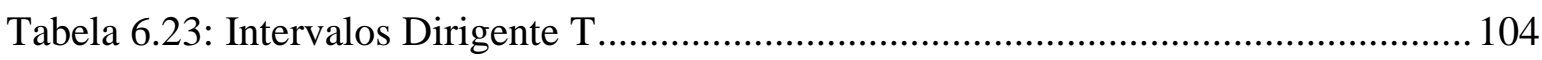

Tabela 6.24: Resumo Contatos Pessoais Dirigente T...................................................... 105

Tabela 6.25: Meios de Contato Pessoal Dirigente T ....................................................... 105

Tabela 6.26: Participantes Contato Pessoal Dirigente T .................................................. 105

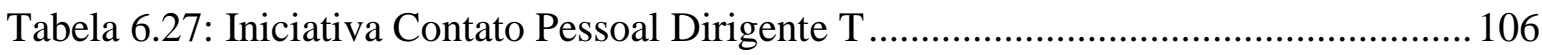

Tabela 6.28: Lugar Contato Pessoal Dirigente T ............................................................... 106

Tabela 6.29: Resumo das Categorias Análise Cronológica Dirigente Z e T..................... 107

Tabela 6.30: Atividades Mesa de Trabalho Dirigente Z e T ........................................... 107

Tabela 6.31: Ligações Telefônicas Dirigente Z e T ............................................................ 107

Tabela 6.32: Reuniões Agendadas Dirigente Z e T ....................................................... 108 
Tabela 6.33: Reuniões Não Agendadas Dirigente Z e T...............................................108

Tabela 6.34: Visita Interna Empresa Dirigente Z e T .....................................................108

Tabela 6.35: Visita Externa Empresa Dirigente Z e T .....................................................109

Tabela 6.36: Viagem de Trabalho Dirigente Z e T .........................................................109

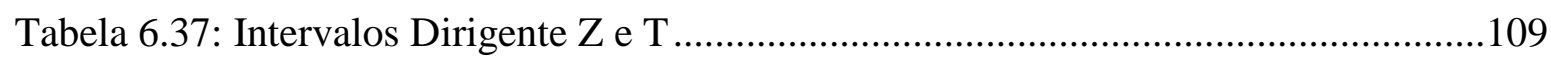

Tabela 6.38: Resumo das Categorias Contatos Pessoais Dirigente Z e T..........................110

Tabela 6.39: Meios de Contato Pessoal Dirigente Z e T ..................................................110

Tabela 6.40: Participantes Contato Pessoal Dirigente Z e T.............................................110

Tabela 6.41: Iniciativa Contato Pessoal Dirigente Z e T .................................................110

Tabela 6.42: Lugar Contato Pessoal Dirigente Z e T.......................................................111

Tabela 7.1: Comparativo Categorias Mintzberg (1973) e Dirigentes Z e T (2011)............114

Tabela 7.2: Meios de Contato: Comparativo Mintzberg (1973)

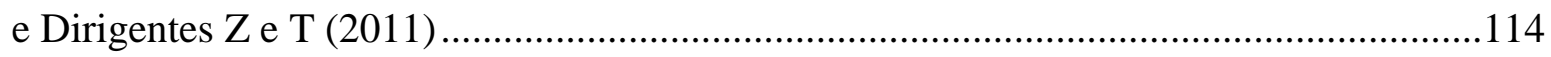

Tabela 7.3: Participantes: Comparativo Mintzberg (1973) e Dirigentes Z e T (2011).......115

Tabela 7.4: Lugar: Comparativo Mintzberg (1973) e Dirigentes Z e T (2011) ..................115

Tabela 7.5: Mesa de Trabalho: Comparativo Mintzberg (1973)

e Dirigentes Z e T (2011)

Tabela 7.6: Ligações Telefônicas: Comparativo Mintzberg (1973)

e Dirigentes Z e T (2011)

Tabela 7.7: Reuniões Agendadas: Comparativo Mintzberg (1973)

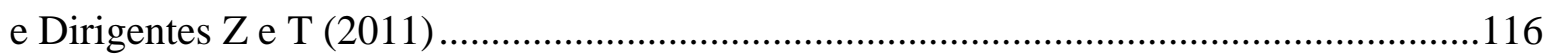

Tabela 7.8: Reuniões Não Agendadas: Comparativo Mintzberg (1973)

e Dirigentes Z e T (2011)

Tabela 7.9: Visita Interna: Comparativo Mintzberg (1973)

e Dirigentes Z e T (2011). 


\section{LISTA DE ABREVIATURAS E SIGLAS}

DEP - Departamento de Engenharia de Produção

EESC - Escola de Engenharia de São Carlos

GEOPE - Grupo de Estudos Organizacionais da Pequena Empresa

IBGE - Instituto Brasileiro de Geografia e Estatística

PIB - Produto Interno Bruto

POSDCORB - Planning, Organizing, Staffing, Directing, CO-ordinating, Reporting, Budgeting

SEBRAE - Serviço Brasileiro de Apoio às Micro e Pequenas Empresas

USP - Universidade de São Paulo 



\section{SUMÁRIO}

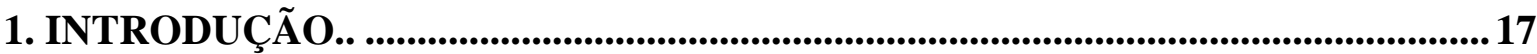

1.1 Caracterização do Tema da Pesquisa ......................................................................18

1.2 Formulação do Problema de Pesquisa..........................................................................19

1.3 Declaração de Objetivos da Pesquisa .................................................................................19

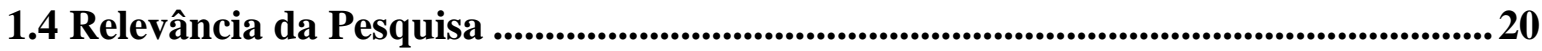

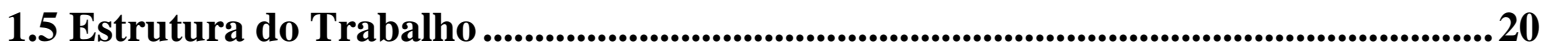

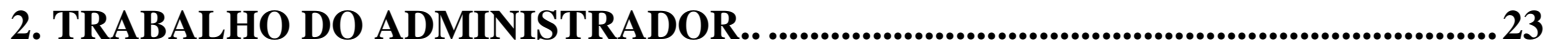

2.1 Contextualização das Abordagens ......................................................................................23

2.2 Características e a Natureza do Trabalho do Administrador ...................................26

2.3 Contribuição de Mintzberg .........................................................................................29

2.3.1 Modelo da Abordagem dos Papéis ..........................................................................29

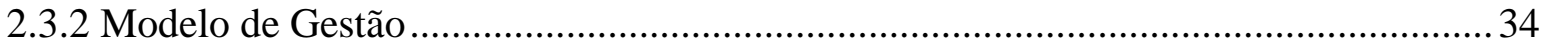

2.3.3 Estudos Empíricos Utilizando o Modelo dos Papéis...................................................36

2.3.4 Críticas ao Modelo da Abordagem dos Papéis ................................................................ 37

2.4 Contribuição de Stewart ............................................................................................................39

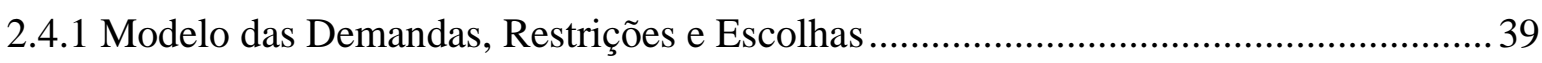

2.4.2 Implicações do Modelo para a Pesquisa................................................................ 42

3. ESPECIFICIDADES DE GESTÃO DA PEQUENA EMPRESA...............................43

3.1 A Importância do Estudo da Pequena Empresa ........................................................43

3.2 Critérios para Classificação da Pequena Empresa ............................................................45

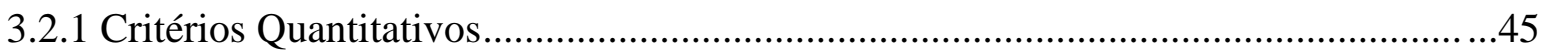

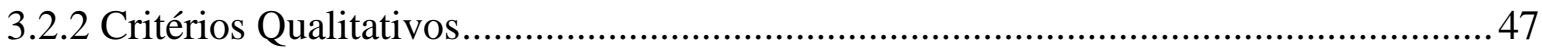

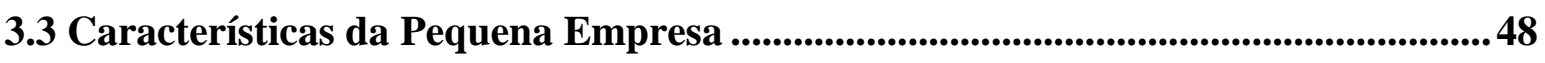

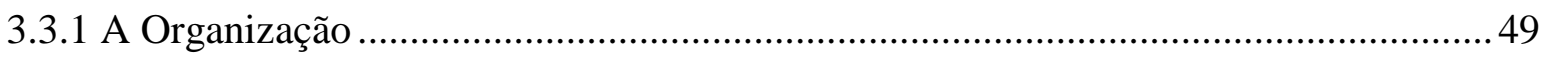

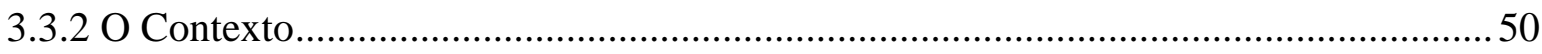

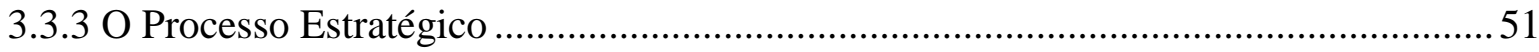

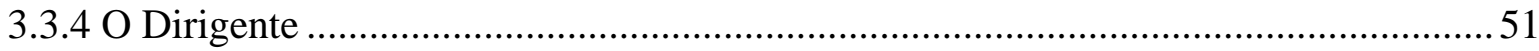

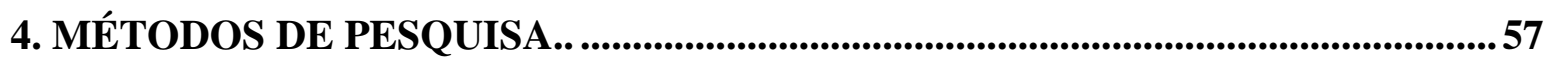

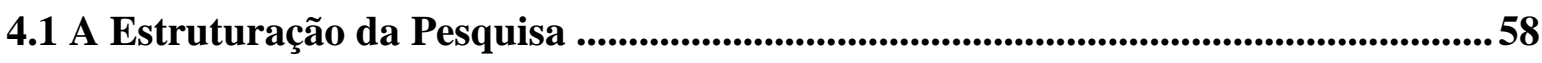

4.2 Alegação de Conhecimento: Abordagem Qualitativa .........................................59

4.3 A Estratégia de Pesquisa: o Estudo de Caso ...................................................661

4.4 Características Pessoais e o Papel do Pesquisador ......................................................66

4.5 Técnicas de Coleta de Dados ...................................................................................68 


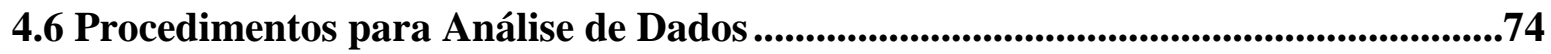

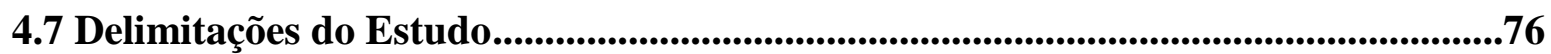

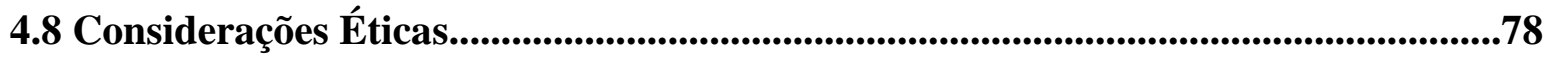

5. TRABALHO DE CAMPO.......................................................................................81

5.1 Informações Preliminares .............................................................................................81

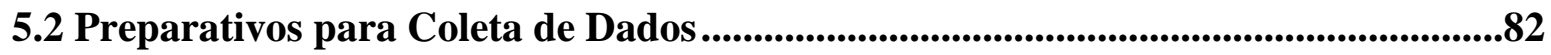

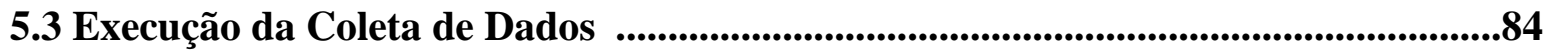

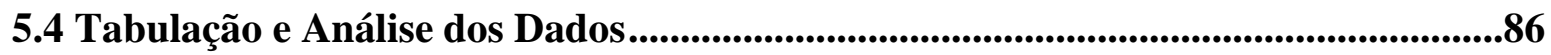

5.5 Estudo de Caso do Dirigente da Empresa $Z$...............................................................8.87

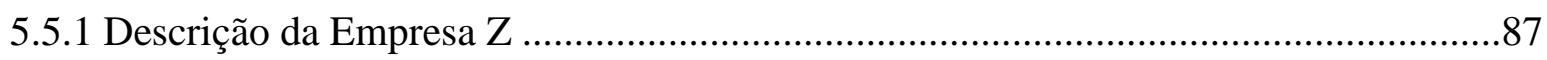

5.5.2 Descrição do Dirigente da Empresa Z ..................................................................90

5.6 Estudo de Caso do Dirigente da Empresa T ...................................................................91

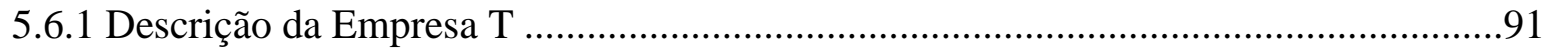

5.6.2 Descrição do Dirigente da Empresa T .....................................................................92

6. APRESENTAÇÃO E ANÁLISE DOS DADOS....................................................95

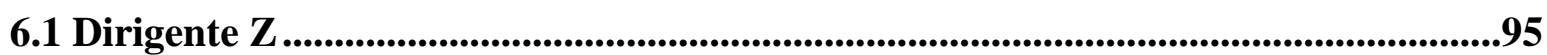

6.1.1 Análise Cronológica das Atividades do Dirigente Z ..............................................95

6.1.2 Análise dos Contatos Pessoais do Dirigente Z ......................................................100

6.2 Dirigente $T$............................................................................................................................102

6.2.1 Análise Cronológica das Atividades do Dirigente T ..............................................102

6.2.2 Análise dos Contatos Pessoais do Dirigente T........................................................105

6.3 Análise Comparativa entre os Casos dos Dirigentes $\mathrm{Z}$ e $T$.....................................106

6.3.1 Análise Cronológica das Atividades dos Dirigentes Z e T .......................................106

6.3.2 Análise dos Contatos Pessoais dos Dirigentes Z e T ...............................................109

7. ANÁLISE ENTRE TEORIA E PRÁTICA NO TRABALHO DO

ADMINISTRADOR DA PEQUENA EMPRESA........................................................113

7.1 Comparativo entre Dirigentes Estudados e Contribuições de Mintzberg

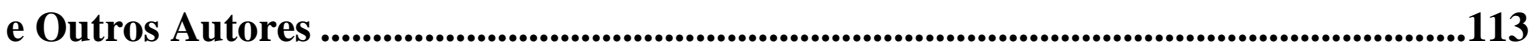

7.2 Comparativo entre Dirigentes Estudados e Contribuição de Stewart ....................119

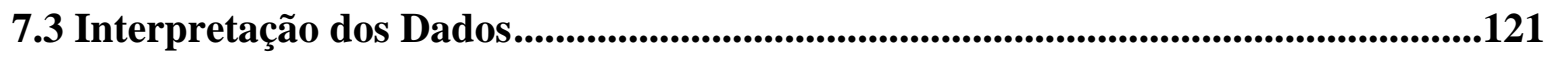

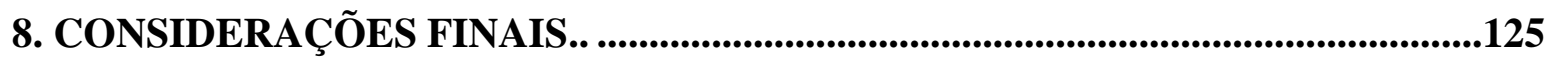

8.1 Sobre o Objetivo da Pesquisa..................................................................................125

8.2 Contribuição da Pesquisa .......................................................................................126

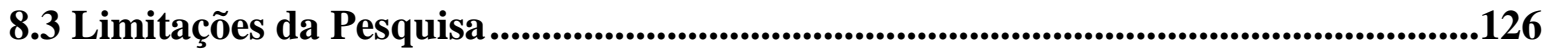




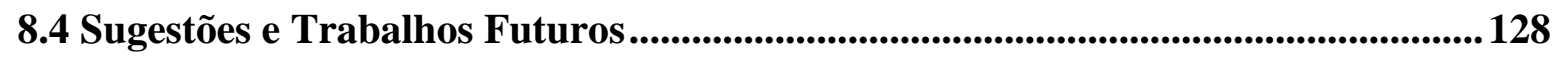

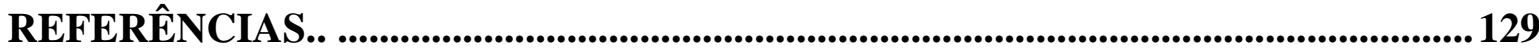

APÊNDICE A - CARACTERIZAÇÃO EMPRESA E DIRIGENTE ........................134

APÊNDICE B - OFICÍO DE PESQUISA ...................................................................... 135

APÊNDICE C - PROTOCOLO DE PESQUISA ........................................................136

APÊNDICE D - INSTRUMENTO COLETA DE DADOS.............................................. 140

APÊNDICE E - LAYOUT PLANILHA EXCEL...........................................................142

APÊNDICE F - CRONOLOGIA ATIVIDADES DIRIGENTE................................... 144

APÊNDICE G - CONTATOS PESSOAIS DIRIGENTE ........................................145

APÊNDICE H - OFÍCIO AGRADECIMENTO DIRIGENTE ..................................146

APÊNDICE I - OFICIO AGRADECIMENTO COORDENADOR

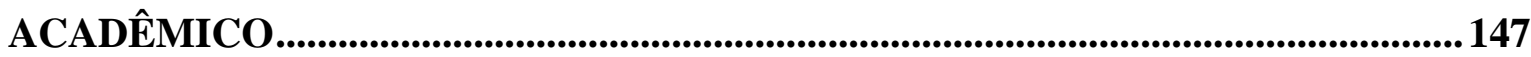





\section{INTRODUÇÃO}

Desde a contribuição pioneira de Fayol e seguidores nas primeiras décadas do século XX muito foi pesquisado, descrito, explicado e debatido a respeito do trabalho do administrador nos últimos cem anos. Consequentemente, resultante dessa longa tradição, o corpo de conhecimento sobre o tema, em especial a natureza do trabalho do administrador, é bem desenvolvido (ANDERSSON, FLORÉN, 2008), embora, ainda possam ser estudados em outros contextos, indústrias e ambientes organizacionais (JACKSON; PETERSON, 2004), em especial, na pequena empresa.

$\mathrm{O}$ interesse em estudar a pequena empresa pode-se justificar pela sua importância econômica e social em escala mundial, comprovada por meio da representatividade no número de estabelecimentos, geração de empregos e formação do produto nacional brasileiro e de vários países industrializados (SEBRAE, 2010; FULLER, 2003).

De forma também relevante, elas contribuem na preservação da estabilidade e dinâmica da economia de mercado, produzindo e oferecendo serviços inovadores e atingindo mercados de pouco interesse ou difícil acesso aos seus pares de grande porte. Destarte, as pequenas empresas são agentes de sustentabilidade na multiplicação e renovação de negócios para o crescimento e diversificação da economia (JULIEN, 1997; FULLER, 2003; BEAVER; JENNINGS; GRAY; MABEY, 2005).

Mas, pequenas empresas não são “pequenas grandes empresas”. Elas têm suas especificidades organizacionais, contextuais, estratégicas e, principalmente, diretivas que as tornam singulares em vários aspectos: informalidade, proximidade, simplicidade, centralização, escassez de recursos, entre outras.

Para entendê-las é preciso estudá-las profunda e sistematicamente, o que tem sido interesse de muitos pesquisadores. Todavia, uma área de investigação que ainda é carente de conhecimento na literatura sobre a pequena empresa, pelo limitado número de pesquisas, é o estudo do trabalho do seu dirigente (O’GORMAN et al., 2005).

Portanto, a forte inter-relação entre o individuo e o negócio é fundamental na teoria da pequena empresa. E, para seu dirigente, tem um significado muito mais amplo: a sua personalidade individual é integrada com seu negócio como reflexo de sua identidade. 


\subsection{Caracterização do Tema da Pesquisa}

O estudo do trabalho do administrador é um dos temas centrais da teoria geral da administração e vem sendo objeto de estudo há quase cem anos, desde que Fayol escreveu sua obra na França em 1916, dando início à chamada escola clássica de administração (LAMOND, 2003).

No início dos anos 1950, Carlson (1951) contribuiu para o desenvolvimento do tema com seu reconhecido pioneirismo metodológico ao escrever o livro Executive Behaviour (1951). Sua obra é considerada um marco teórico (STEWART, 1998), pois, a partir de um estudo empírico, descreveu o que o administrador realmente faz, diferente da visão clássica de Fayol e seus seguidores com sua abordagem prescritiva: o que o administrador deveria fazer.

Nos últimos quarenta anos do século $\mathrm{XX}$, um considerável avanço ocorreu com a publicação de diversos estudos empíricos e modelos teóricos sobre o trabalho do administrador. Nesse período, Stewart, Mintzberg, Kotter e Hales dedicaram-se ao estudo prático do tema, com a aplicação de diversos métodos e técnicas investigativas para colher dados diretamente no ambiente empresarial por meio de observações, entrevistas e diários.

Em particular, destaca-se pela originalidade, rigor e consistência do trabalho de Mintzberg (1970, 1971, 1973, 1986, 1994, 1997, 1998, 2010), com seu modelo e constructo teórico dos papéis desempenhados pelo administrador, e Stewart (1982, 1998, 2008) com a formulação teórica das demandas, restrições e escolhas.

Embora o amplo arcabouço teórico construído, em especial nos últimos 60 anos, ofereça uma base de conhecimento bastante extensa, ela não é completamente exaustiva, pois ainda há espaço para novos estudos que explorem mais profundamente o tema do trabalho do administrador, em particular, tendo como objeto a pequena empresa (FLORÉN, 2006). 


\subsection{Formulação do Problema de Pesquisa}

Estudos sobre a natureza do trabalho do administrador, em suas mais variadas abordagens, são bastante extensos e têm longa tradição, portanto, estão bem desenvolvidos. Contudo, a literatura sobre a pequena empresa é comparativamente escassa, insuficiente e pouco esforço tem sido feito para explorar o assunto (ANDERSSON; FLORÉN, 2008; FLORÉN, 2006). Consequentemente, o conhecimento sobre o trabalho do administrador da pequena empresa é mais limitado ainda (O’GORMAN et al., 2005).

De maneira geral, o que se sabe a respeito da natureza do trabalho do dirigente da pequena empresa é fruto de explicações baseadas em modelos desenvolvidos e aplicados em grandes empresas. O que, em grande parte, limita o conhecimento pleno dos elementos substantivos que constituem o trabalho do dirigente da pequena empresa: aquilo que ele faz, a distribuição do tempo entre suas diferentes atividades, as interações e meios utilizados na comunicação e os elementos informais inerentes às atividades cotidianas.

Assim, o problema de pesquisa tem por objetivo contribuir para o avanço nas discussões e entendimento sobre o trabalho cotidiano do dirigente da pequena empresa, resume-se a questão:

\section{As abordagens do trabalho do administrador têm eficácia na explicação da natureza do trabalho do dirigente da pequena empresa?}

\subsection{Declaração de Objetivos da Pesquisa}

O objetivo geral da pesquisa é avaliar as coerências e divergências entre a explicação da natureza do trabalho do dirigente da pequena empresa e as teorizações existentes na literatura administrativa.

Como objetivos específicos pretende-se:

(1) Verificar as características do trabalho do dirigente da pequena empresa segundo quatro dimensões: tipo de atividade, lugar, participantes e iniciativas de contato;

(2) Verificar o conteúdo do trabalho do dirigente da pequena empresa: os papéis desempenhados aplicando o constructo do modelo de Mintzberg (1971, 1973, 2010). 
(3) Identificar as semelhanças e diferenças nas características e papéis entre os casos múltiplos estudados: análise cruzada de casos; e

(4) Interpretar as possíveis diferenças entre as características do trabalho dos dirigentes aplicando a estrutura teórica o modelo das demandas, restrições e escolhas de Stewart (1982, 1998, 2008).

\subsection{Relevância da Pesquisa}

As pequenas empresas têm importância econômica e social em escala mundial, dado seu grande número de estabelecimentos, participação na geração de empregos e formação do produto nacional (SEBRAE, 2010; FULLER, 2003). Elas também têm um papel significativo na preservação da estabilidade e dinâmica da economia de mercado com a oferta de produtos inovadores e complementaridade de serviços com seus pares de grande porte.

Todavia, é marcante a importância do papel do seu dirigente, pois a empresa e sua pessoa se confundem, uma vez que exerce influência direta em toda sua administração (JULIEN, 1997; BEAVER; JENNINGS, 2000).

Portanto, o trabalho de pesquisa justifica-se pelo propósito de contribuir com:

- Estudos organizacionais voltados para o desenvolvimento de uma teoria administrativa para a pequena empresa;

- Dirigente da pequena empresa que deseja conhecer a teoria sobre o trabalho do administrador;

- Trabalhos acadêmicos visando despertar o interesse em futuras investigações sobre o tema e o objeto de estudo;

- Projetos de consultoria organizacional voltados para pequenas empresas;

- Trabalhos educacionais de capacitação profissional dos dirigentes da pequena empresa.

\subsection{Estrutura do Trabalho}

O presente trabalho é divido em oito capítulos, sendo o primeiro, conforme já apresentado, referente à concepção epistemológica do trabalho como a caracterização do tema, o problema de pesquisa, os objetivos geral e específicos e a justificativa. 
O Capítulo 2 aborda o tema da pesquisa, o trabalho do administrador, partindo de sua contextualização, características, as contribuições de Mintzberg e seu modelo dos papéis administrativos e Stewart com o modelo das demandas, restrições e escolhas, ambas as estruturas conceituais a serem utilizadas na investigação e análise dos dados de campo.

O Capítulo 3 trata do objeto de estudo da pesquisa: a pequena empresa. Nas suas seções são apresentadas a importância do estudo da pequena empresa, os critérios de classificação (quantitativos e qualitativos) e as características da pequena empresa a partir de suas especificidades de gestão: o dirigente, a organização, o contexto e o processo estratégico.

O Capítulo 4 tem o foco no pólo metodológico da pesquisa. Nele serão apresentadas a estrutura da pesquisa, a alegação de conhecimento (paradigma de pesquisa), a estratégia de pesquisa adotada: o estudo de caso, as características pessoais e o papel do pesquisador, as técnicas de coleta e os procedimentos de análise de dados a serem usadas, as delimitações do estudo e, por fim, as considerações éticas e suas práticas.

O Capítulo 5 traz as informações preliminares sobre o trabalho de coleta de dados no campo, por exemplo, os critérios de seleção das empresas, os preparativos para a coleta com os tipos de registros utilizados e as medidas preventivas para assegurar a qualidade do trabalho. Também, são apresentados informações sobre a execução com a duração e o período, a tabulação e análise dos dados, bem como, a descrição dos dois casos estudados.

O Capítulo 6 expõe os resultados da coleta e análise dos dados da pesquisa de campo, de forma individual e comparativamente entre os casos, contemplando a análise cronológica das atividades dos dirigentes e seus contatos pessoais pelos meios usados. O objetivo no capítulo é desenvolver algumas análises e tecer comentários a respeito dos resultados possibilitando melhor entendimento dos fatos.

O capítulo 7 contrapõe os resultados da pesquisa com as teorias sobre o trabalho do administrador. As diferenças encontradas entre as características do trabalho dos dirigentes são analisadas aplicando a estrutura teórica do modelo Stewart (1982, 1998, 2008), assim como são identificados os papéis executados de forma mais intensa pelos dirigentes.

O Capítulo 8 finaliza o trabalho resgatando aspectos importantes do objetivo da pesquisa e a proposta de contribuição para o desenvolvimento do tema. Alguns alertas sobre as limitações do estudo, em relação ao método e aspectos práticos são apresentados ao 
leitor, da mesma forma que são oferecidas sugestões de melhoria para futuros projetos de pesquisa. 


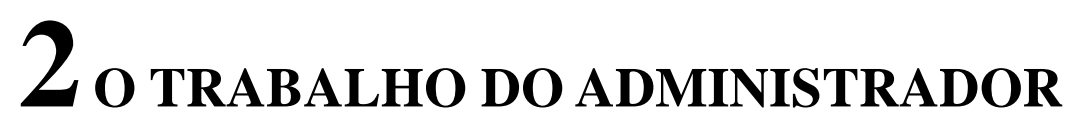

Este capítulo tem o propósito de explorar o tema da pesquisa - o trabalho do administrador - e foi organizado em quatro seções: a contextualização das abordagens já desenvolvidas, as características e natureza do trabalho e os modelos originários das contribuições de Mintzberg e Stewart para o assunto.

Para contextualização das abordagens, seis diferentes autores foram selecionados pela sua relevância histórica neste século de estudo do trabalho do administrador: os clássicos Fayol (1965) e Drucker (1998) com suas contribuições teóricas e Carlson (1951), Mintzberg (1973), Stewart (1982) e Kotter (1982), todos com trabalhos respaldados por estudos empíricos.

Partindo das abordagens, a segunda seção trata das características e a natureza do trabalho do administrador. Nela são colocadas em perspectiva duas linhas de pensamento: o que o administrador deve fazer (visão clássica) e o que o administrador de fato faz no seu cotidiano quando se relaciona com outras pessoas, administra seu tempo e desempenha suas tarefas.

Poucos autores compreenderam tão bem a natureza do trabalho do administrador como Mintzberg (modelo dos papéis) e Stewart (modelo das demandas, restrições e escolhas). Portanto, a terceira e a quarta seções são dedicadas exclusivamente para eles e encerram o capítulo expondo suas contribuições teóricas e modelos.

\subsection{Contextualização das Abordagens}

O estudo da natureza do trabalho do administrador foi pesquisado por todo o século XX e ainda é objeto de interesse no século XXI. Durante todo este período, alguns modelos teóricos buscaram explicar as características e a forma como o trabalho é, ou deveria ser, realizado pelo administrador. Podem-se mencionar, em especial pela sua relevância, as seguintes contribuições:

- Fayol (1965) e seus seguidores - precursor da visão clássica, sua obra foi escrita na França em 1916 e traduzida para o inglês em 1949 (LAMOND, 2003). Fayol descrevia as funções do administrador como sendo prever, organizar, comandar, coordenar e controlar. 
Trata-se de uma abordagem prescritiva sobre o que o administrador deve fazer no exercício da sua função e não o que de fato executa. De acordo com Hampton (1980), Gulick e Urwick seguiram a mesma linha de pensamento de Fayol, resumindo sua ideia no acrograma (em inglês) POSDCORB (planejamento, organização, pessoal, direção, coordenação, relatório e orçamento). Embora a abordagem de Fayol tenha recebido críticas pelo fato de não ser observável na prática (MINTZBERG, 1986), ela resiste ao tempo com uma “[...] longevidade notável na qualidade de sua estrutura básica para o entendimento da função do administrador.” (WREN, 2007).

- Drucker (1998) - há mais de meio século, desde 1954, Drucker colocou a gestão em evidência (MINTZBERG, 2010). Ele descreve o administrador como essencial para o sucesso do negócio e da sociedade, fazendo uma analogia entre sua atividade na empresa com o regente de uma orquestra sinfônica: de seu pedestal, é o compositor e maestro ao mesmo tempo, organizando e conduzindo harmoniosamente as partes instrumentais. Drucker tem uma visão sobre o trabalho do administrador que se aproxima da escola clássica com ênfase naquilo que o administrador deve fazer: planejar e estabelecer objetivos, organizar as atividades, comandar, coordenar (motivar as pessoas e comunicar) e controlar os resultados.

- Carlson (1951) - é reconhecido pelo seu pioneirismo metodológico, relevância e originalidade nas contribuições para o entendimento do que realmente faz o administrador (MINTZBERG, 1971, 2010; STEWART, 1998). Em seu livro Executive Behaviour (1951), Carlson descreve algumas características, confirmadas em estudos posteriores, sobre o trabalho do administrador como a fragmentação e o pouco tempo despendido em atividades isoladas e ininterruptas (STEWART, 1998). Portanto, diferente do caráter deliberado, analítico e lógico sugerido por Fayol na visão clássica do administrador como um planejador sistemático e reflexivo (WREN, 2007).

- Mintzberg (1973) e Stewart (1982) - Influenciados pelo trabalho de Carlson (1951), Henry Mintzberg e Rosemary Stewart são considerados dois importantes pesquisadores sobre o tema do trabalho do administrador (MARTINKO; GARDNER, 1985; LOWE, 2003; TENGBLAD, 2006). Eles aplicaram em seus estudos uma variedade de métodos de pesquisa - observações estruturadas, entrevistas em profundidade e uso de diários (MINTZBERG, 1970, 1971, 1973; STEWART, 1979) - cujo foco era entender como se constituía na prática e quais as características do trabalho do administrador: onde desempenham seu trabalho, com quem o fazem e se relacionam, quanto tempo duram suas 
atividades e de quais meios se utilizam para comunicação e contato (LAMOND, 2003). Com trabalhos realizados por várias décadas, Mintzberg e Stewart propuseram teorias e modelos explicativos com destaque para os papéis do administrador (MINTZBERG 1971, 1973, 1994) e o modelo das demandas, restrições e escolhas (STEWART 1982, 1998, 2008).

- Kotter (1982) - partindo de estudo empírico, apresentou as atividades do administrador caracteristicamente como gerenciar (elaborar planos, organizar o pessoal, controlar e resolver problemas) e liderar (estabelecer direção, alinhar, motivar e inspirar pessoas). Cabe a ele definir uma agenda, criar redes de relacionamento e cooperação e usá-las para implantar sua agenda. Pela observação do padrão de comportamento diário dos administradores gerais, Kotter concluiu que é difícil conciliá-lo com as ideias tradicionais de prever, organizar, comandar, coordenar e controlar, descritas pela visão clássica. $\mathrm{Na}$ verdade, os administradores passam a maior parte do tempo com outras pessoas; abordam temas de grande abrangência informalmente em conversas rápidas e soltas; raramente parecem tomar grandes decisões e dar ordens no sentido tradicional, preferindo usar sua influência; trabalham muitas horas por dia e não parecem seguir nenhum tipo de planejamento pessoal.

Um número substantivo de outros estudos se propôs testar, replicar ou questionar as teorizações sobre o trabalho do administrador. Eles abordaram uma grande variedade de temas como: o que fazem os administradores de sucesso (contatos externos e socialização, gestão de conflitos, tomada de decisão e planejamento); metodologias empregadas (observação estruturada, diários e auto-observação); as características distintivas das tarefas do administrador (interdependência, ausência de padrão, inovação e resultados indiretos); relações com a estrutura organizacional (grau de centralização e descentralização, divisão de trabalho e autonomia); os efeitos das mudanças nas estruturas organizacionais sobre o trabalho do administrador (estruturas burocráticas e em rede); o trabalho do administrador nos serviços de atenção à saúde (médicos e enfermeiras); replicação dos estudos clássicos (Mintzberg, 1973 e Carlson, 1951); preferências dos administradores (liderar empregados, relacionamento e inovação); revisão teórica de abordagens (Fayol e Mintzberg); o trabalho do administrador na área de educação (faculdades, universidades, públicas e privadas); os papéis administrativos dos profissionais de tecnologia da informação (diretores executivos em empresas norueguesas); e o desempenho da informação no trabalho do administrador (relação entre contexto, trabalho do administrador e importância da informação) (LUTHANS; 
ROSENKRANTZ; HENNESSEY, 1985; MARTINKO; GARDNER, 1985; WHITLEY, 1989; HALES; TAMANGANI, 1996; HALES, 2002; ARMAN et al., 2009; TENGBLAD, 2002, 2006; KONRAD et al., 2001; LAMOND, 2003; MECH, 1997; LAITINEN, 2009).

\subsection{Características e a Natureza do Trabalho do Administrador}

Segundo Mintzberg (1986, 2010), a escola clássica da administração, representada por Fayol e seus seguidores, caracteriza o administrador como um planejador reflexivo e sistemático; dependente de informações agregadas, cuja melhor fonte é um sistema formal; gestor de relações hierárquicas entre um "superior" e seus "subordinados"; e um controlador rígido de seu tempo, de suas atividades, de suas unidades.

De outra forma, seria caracterizar o trabalho do administrador como a ação sistemática e processualista de planejar, organizar, comandar, coordenar e controlar (FAYOL, 1965). Porém, os diversos estudos empíricos realizados desde a segunda metade do século XX, com destaque para o trabalho de Carlson (1951) com seu pioneirismo metodológico, relevância e originalidade, apontaram para uma situação observada na prática de forma diferente.

Noordegraaf e Stewart (2000) afirmam que o objeto de estudo na abordagem comportamental do trabalho do administrador é o individuo, portanto, nessa condição, três tipos de dados sobre suas características são coletados: de fundo socioeconômico, mental e comportamental. Os autores afirmam ainda que a unidade de análise não são questões organizacionais especificas ou processos decisórios, mas o individuo, como ator, envolvido em múltiplas questões e processos a ser estudado e analisado de forma indutiva naquilo que ele de fato faz em todas suas atividades no papel de administrador.

Hales (1999) coloca que há três principais aspectos do trabalho do administrador que parecem ser comuns a todos eles: certas atividades ou processos administrativos genéricos, áreas-chave importantes onde as atividades ocorrem e os aspectos característicos dessas atividades.

Whitley (1989) aborda outro aspecto importante sobre o trabalho do administrador relacionado às características distintivas das suas tarefas, como sendo: altamente interdependentes, contextuais e sistêmicas; relativamente sem padrão; instáveis e evolutivas; paradoxalmente, servem tanto para manutenção da estrutura administrativa como sua mudança e melhoria pela inovação; e raramente geram resultados visíveis separados que podem ser diretamente ligados aos indivíduos. 
Conforme Konrad et al. (2001), o trabalho administrativo pode ser entendido como o conjunto de atividades intencionadas a manter o processo organizacional, iniciativas (agendas) de mudança organizacional e construção de relacionamentos interpessoais. E Mintzberg (1973) afirma que o trabalho administrativo consiste em três elementos básicos: primeiro, o administrador interage com outras pessoas; segundo, processa informação; e terceiro, toma decisões.

Para colocar em prática sua agenda e planos, o administrador desenvolve uma rede de contatos de apoio interno e externo indo além dos limites de suas responsabilidades. Com isso, frequentemente, atua como negociador que necessita da cooperação de todas as partes interessadas e pratica, submetido a certo grau de tensão na solução de demandas, sua habilidade para interpretar os pensamentos e os desejos de empregados, clientes, fornecedores, concorrentes e governos (STEWART, 2008; KONRAD et al., 2001; HALES, 1999).

Por ocupar posição superior ou intermediária dentro das empresas, frequentemente envolvendo a tomada de decisões, o administrador, geralmente, recebe mais informações do que oferece, vindas de diferentes origens (internas e externas) e age como figura-chave, representante ou ponto de contato de sua unidade de trabalho (MINTZBERG, 1971; HALES, 1999, 2001).

O controle e a disseminação das informações são essenciais para executar seu trabalho eficazmente defendendo o interesse da sua unidade, em particular quando se vale daquelas de natureza informal, as mais abundantes (HALES, 1999, 2001; STEWART, 2008).

Um ponto a destacar é que os administradores preferem assuntos que envolvam informações ágeis, instantâneas, esporádicas e não planejadas, reagindo a eventos, problemas e solicitações de outros. Assim, a comunicação constitui uma característica importante na natureza do trabalho do administrador e ocorre, em geral, de forma direta e informal, com alto nível de interação verbal (telefone, reuniões, visitas pelas instalações da empresa) e frequentemente face a face, em detrimento da escrita (MINTZBERG, 1971, 1973, 1986, 2010; KOTTER, 1982; HALES, 1999).

Uma das principais características na natureza do trabalho do administrador é a grande quantidade de atividades desenvolvidas, geralmente conduzidas em um ritmo intenso, e executadas de forma variada, breve, fragmentada, de curta duração e descontínuas. Isso porque, raramente, os administradores estão sozinhos e tampouco permanecem por um longo 
período sem interrupção, mudando com freqüência sua atenção nos assuntos e interlocutores, não parecendo seguir um planejamento formal para isso e sentindo-se mais confortáveis agindo dessa forma do que mantendo o foco em uma atividade particular (MINTZBERG, 1971, 1973, 2010; HALES 1999, 2001; KOTTER, 1982; STEWART, 2008).

Contudo, a percepção do uso do tempo é muito relativa, pois os administradores acreditam que gastam mais tempo com algumas atividades do que com outras, diferentemente daquilo que pode ser observado empiricamente (STEWART, 2008).

Parte significativa deste tempo é gasto com viagens e atividades realizadas externamente, em especial na realidade contemporânea como resultado de empresas cada vez mais globalizadas (TENGBLAD, 2002, 2006). Embora as atividades possam ser aplicadas em diversas funções gerenciais, Hales $(1999,2002)$ afirmou que os administradores parecem preocupados com o "micro-gerenciamento" da rotina do dia-a-dia, como "apagadores de incêndios", dedicando, geralmente, considerável proporção do seu tempo e esforço com atividades relativas: à gestão de pessoas e informações; monitoração e manutenção cotidiana dos processos de trabalho; busca de novas oportunidades de negócio; e execução de atividades não-gerenciais como assistência em trabalhos de caráter técnico.

Porém, além de decidir, cabe ao administrador planejar e elaborar o cronograma de trabalho de sua equipe, alocar recursos, dirigindo e monitorando o trabalho dos subordinados e resolvendo problemas e conflitos no fluxo das atividades de trabalho (HALES, 1999, 2001).

Ainda que, aparentemente, o administrador tenha o controle dos seus próprios assuntos e afazeres (MINTZBERG, 1971), na prática, necessariamente, não ocorre dessa forma. Pelo contrário, seriam como "escravos" de seus compromissos, frequentemente determinados por outros (STEWART, 2008).

Embora o trabalho dos administradores tenha características comuns, há também uma considerável variação na sua natureza. As diferenciações das atividades acontecem na distribuição dos variados elementos de sua constituição, tipos e padrão de contato, ritmo de trabalho, local onde o trabalho é executado, dependência de outras pessoas, interação envolvida, escolhas disponíveis e influência. Fatores contingenciais como a estrutura organizacional (grau de descentralização), o porte, o ambiente e tipo de indústria contribuem para explicar essas variações (HALES, 1999; 2001; ANDERSSON; FLORÉN, 2009). 


\subsection{Contribuição de Mintzberg}

Henry Mintzberg contribuiu para o entendimento do trabalho do administrador com o desenvolvimento de estudos realizados durante quase quarenta anos $(1971,1973,1986,1994$, 1997 e 2010) quando procurou, de forma indutiva, analisar sistematicamente as atividades desempenhadas pelos administradores e tirar conclusões suportadas por evidências empíricas (LAMOND, 2003).

\subsubsection{Modelo da Abordagem dos Papéis}

Além de caracterizar o trabalho do administrador, Mintzberg (1971, 1973, 1986) coloca que o conteúdo das atividades desenvolvidas por eles corresponde a três dimensões básicas: contatos interpessoais, processamento das informações e tomada de decisões.

Como resultado, o administrador desempenha vários papéis administrativos, dez no total, agrupados em três áreas importantes, formando um conjunto que não pode ser considerado isoladamente (MINTZBERG, 1973, 1986), conforme resumido na Figura 2.1:

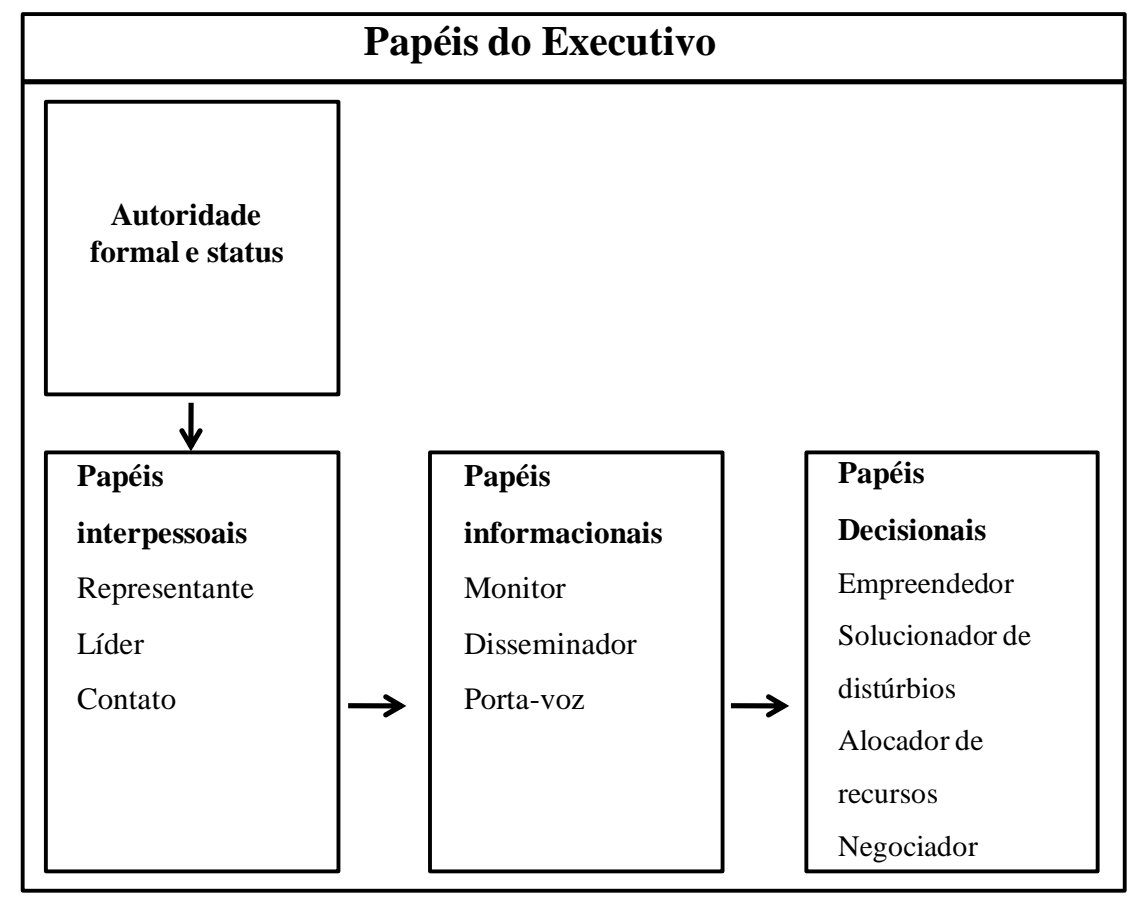

Figura 2.1: Os papéis administrativos Fonte: Mintzberg (1986, p.13) 
Três papéis são classificados como Interpessoais e relacionados ao comportamento do administrador com foco nos seus contatos interpessoais. Derivam diretamente da sua autoridade e status associados ao cargo do administrador:

- Representante: como autoridade legal na sua organização, o administrador é um símbolo obrigado a cumprir uma série de tarefas como deveres de caráter cerimonial, assinar documentos legais, receber visitantes e estar à disposição para tratar de assuntos específicos da alta gestão da empresa.

- Líder: é o relacionamento do administrador com seus subordinados para motivá-los a desenvolver seu trabalho, portanto, presente em muitas das suas atividades.

- Contato: a comunicação em diferentes direções e níveis é muito importante para o executivo realizar seu trabalho. Assim, ele desenvolve uma rede de contatos que trarão informações úteis e de interesse para si e sua empresa. Fazendo uso de seu status, o administrador interage com outros colegas e pessoas fora da sua organização, provendo informações e favores de forma a receber em troca o mesmo.

Relacionados primariamente ao processamento das informações, os três papéis Informacionais descrevem o administrador como ponto focal para certos tipos de informação organizacional e sua transmissão:

- Centro nervoso ou Monitor: o administrador serve de ponto focal na sua empresa para o trânsito de informações não rotineiras, tendo autoridade para formalmente promover conexões com qualquer outro membro. Embora ele não seja um especialista, a exemplo de seus subordinados e pares, ele é um generalista com acesso a informações e conhecimentos de origem interna e externa. Agilidade e informalidade marcam a forma e o conteúdo das informações que são recebidas e repassadas, nem sempre utilizando os canais formais estabelecidos para este fim. O administrador deve estar preparado para lidar com uma variedade de informações que mais se assemelham com fofocas, boatos e especulações.

- Disseminador: muitas das informações gerenciais têm sua origem em agentes influenciadores como governo, sócios, grupos de empregados etc. Muitas vezes essas informações têm valor e significado para a cultura empresarial e devem ser transmitidas e assimiladas pelo público interno. Cabe ao administrador a tarefa de fazê-lo de forma a integrar e dar aderência no pensamento interno da empresa. 
- Porta-voz: neste papel, o administrador é obrigado a transmitir suas informações para agentes externos. Ele divulgará para influenciadores e demais partes interessadas sobre o desempenho da empresa, suas políticas e planos. É também esperado que ele sirva como um expert para tratar sobre questões relativas à indústria que a empresa atua.

Quatro papéis descrevem o controle que o administrador tem sobre aspectos Decisionais do negócio:

- Empreendedor: é o administrador como iniciador e designer das mudanças na organização, identificando oportunidades para serem exploradas ou projetos de melhoria envolvendo diferentes demandas do negócio: marketing, vendas, produção etc. O administrador agirá em várias frentes simultaneamente, podendo delegar responsabilidades para seus subordinados ou supervisionar pessoalmente o processo.

- Solucionador de distúrbios: diferentemente do empreendedor, que é quem inicia suas ações, no papel de solucionador de distúrbios o administrador lida com situações involuntárias que é obrigado a agir corretivamente. Grande parte delas são distúrbios originados de episódios não resolvidos pelos especialistas e requerem uma visão generalista para sua solução por envolverem várias áreas ou etapas de processos. Visão esta que só o administrador consegue ter, dada a perspectiva abrangente que tem da empresa.

- Alocador de recursos: o administrador é quem controla os recursos e define onde eles serão empregados. Por decidir quem ficará com o que ele dá direção para sua empresa. $\mathrm{O}$ meio como ele o faz acontece de três formas: alocando seu tempo e, consequentemente, definindo prioridades; desenhando a estrutura organizacional e programando o trabalho de seus subordinados; e mantendo o controle por meio da centralização das decisões antes das ações serem implantadas. É uma forma de coordenação, muitas vezes usando tipos de modelos e planos mentais, para assegurar que os objetivos sejam atingidos e os recursos consumidos adequadamente.

- Negociador: a negociação é uma atividade inerente ao trabalho do administrador seja com grupos internos ou externos. Ele é a autoridade legal e representará os interesses da organização, visto que é seu porta-voz e alocador de recursos.

Mintzberg (1973) ressaltou que os dez papéis não são desempenhados de forma homogênea pelos administradores, estando sujeitos a fatores que provocam diferenciações no trabalho do administrador, quais sejam: 
- Tamanho da empresa;

- Indústria ou o setor onde a empresa opera;

- Nível hierárquico do administrador na empresa e seu tipo de função (marketing, manufatura etc.);

- Aspectos pessoais do administrador: seus valores, personalidade, estilo de gestão; e

- Mudanças naturais que ocorrem no trabalho com o passar do tempo.

Os Quadros 2.1, 2.2 e 2.3, adaptados de Oliveira (2010, p.142), apresentam um resumo dos dez papéis do administrador de Mintzberg (1971, 1973, 1986), assim como seus constructos teóricos e respectivas descrições, a saber:

\begin{tabular}{|c|c|c|}
\hline \multicolumn{3}{|c|}{ PAPÉIS INTERPESSOAIS } \\
\hline Papel & Constructo & Descrição \\
\hline \multirow{3}{*}{ Representante } & $\begin{array}{l}\text { Participação em eventos } \\
\text { sociais }\end{array}$ & $\begin{array}{l}\text { Participa de eventos externos: cerimônias de } \\
\text { concessão de prêmios ou entidades de classe. }\end{array}$ \\
\hline & $\begin{array}{l}\text { Atendimento aos } \\
\text { visitantes }\end{array}$ & $\begin{array}{l}\text { Atende as pessoas que procuram a empresa, mas } \\
\text { não são clientes. }\end{array}$ \\
\hline & $\begin{array}{l}\text { Promoção de eventos } \\
\text { sociais }\end{array}$ & $\begin{array}{l}\text { Realiza eventos sociais para promover a imagem } \\
\text { ou produtos da empresa }\end{array}$ \\
\hline \multirow{3}{*}{ Líder } & $\begin{array}{l}\text { Orientação da execução } \\
\text { das tarefas }\end{array}$ & $\begin{array}{l}\text { Define metas de trabalho e comunica ordens e } \\
\text { orientações aos subordinados. }\end{array}$ \\
\hline & $\begin{array}{l}\text { Relacionamento com os } \\
\text { subordinados }\end{array}$ & Critica, reconhece e motiva os subordinados. \\
\hline & Exercício da autoridade & $\begin{array}{l}\text { Percebe que os subordinados compreendem } \\
\text { perfeitamente as orientações, as aceitam e as } \\
\text { cumprem. }\end{array}$ \\
\hline \multirow{3}{*}{ Contato } & Relacionamento interno & $\begin{array}{l}\text { Desenvolve atividades para manter um conjunto } \\
\text { de relações formais e informais dentro da } \\
\text { empresa. }\end{array}$ \\
\hline & Relacionamento externo & $\begin{array}{l}\text { Estabelece relacionamentos profissiona is } \\
\text { externos. }\end{array}$ \\
\hline & $\begin{array}{l}\text { Disseminação de } \\
\text { informações internas }\end{array}$ & $\begin{array}{l}\text { Repassa informações externas importantes aos } \\
\text { funcionários. }\end{array}$ \\
\hline
\end{tabular}




\begin{tabular}{|c|c|c|}
\hline \multicolumn{3}{|c|}{ PAPÉIS INFORMACIONAIS } \\
\hline Papel & Constructo & Descrição \\
\hline \multirow{3}{*}{ Monitor } & Obtenção de informações & Identifica e coleta informações relevantes para a empresa \\
\hline & $\begin{array}{l}\text { Monitoramento das operações } \\
\text { internas }\end{array}$ & $\begin{array}{l}\text { Avalia o desempenho da empresa, a fim de realizar ajustes e } \\
\text { mudanças. }\end{array}$ \\
\hline & $\begin{array}{l}\text { Acompanhamento dos eventos } \\
\text { externos }\end{array}$ & $\begin{array}{l}\text { Verifica o que os competidores fazem e os acontecimentos do } \\
\text { ambiente externo. }\end{array}$ \\
\hline \multirow{3}{*}{ Disseminador } & Seleção de informações & $\begin{array}{l}\text { Classifica quais informações relevantes serão compartilhadas com } \\
\text { os subordinados. }\end{array}$ \\
\hline & Compartilha informações & Compartilha informações relevantes com os subordinados. \\
\hline & $\begin{array}{l}\text { Assegura o recebimento de } \\
\text { informações }\end{array}$ & $\begin{array}{l}\text { Assegura que os subordinados recebam informações relevantes para } \\
\text { a execução da tarefa. }\end{array}$ \\
\hline \multirow{3}{*}{ Porta-voz } & Realização de comunicados & $\begin{array}{l}\text { Concede entrevista ou realiza discursos ou apresenta informações da } \\
\text { empresa para públicos externos. }\end{array}$ \\
\hline & $\begin{array}{l}\text { Comunicação em nome da } \\
\text { empresa }\end{array}$ & $\begin{array}{l}\text { Pronuncia-se sobre a história ou a situação da empresa em eventos } \\
\text { ou reuniões. }\end{array}$ \\
\hline & Representação do setor & Reivindica benefícios para as empresas do setor. \\
\hline
\end{tabular}

Quadro 2.2 - Papéis Infor macionais: construtos teóricos

Fonte: Adaptado de OLIVEIRA (2010, p.142)

\begin{tabular}{|c|c|c|}
\hline \multicolumn{3}{|r|}{ PAPÉIS DECIS IONAIS } \\
\hline Papel & Constructo & Descrição \\
\hline \multirow{3}{*}{ Empreendedor } & Promoção de melhorias & Altera os flu xos de trabalho, a fim de melhorar a produtividade. \\
\hline & $\begin{array}{l}\text { Proposição de } \\
\text { oportunidades }\end{array}$ & Procura por inovações, que possam se tornar projetos da empresa. \\
\hline & $\begin{array}{l}\text { Imple mentação de novos } \\
\text { projetos }\end{array}$ & $\begin{array}{l}\text { Conduz a implantação de projetos de melhoria ou mudança de produto, } \\
\text { serviço e métodos de produção ou de gestão. }\end{array}$ \\
\hline \multirow{3}{*}{$\begin{array}{l}\text { Mani pul ador de } \\
\text { distúr bi os }\end{array}$} & $\begin{array}{l}\text { Resolução de conflitos } \\
\text { rotineiros }\end{array}$ & Resolve os conflitos entre os subordinados, advindos de situações rotineiras. \\
\hline & $\begin{array}{l}\text { Resolução de conflitos } \\
\text { repentinos }\end{array}$ & $\begin{array}{l}\text { Resolve os conflitos entre os subordinados, advindos de situações } \\
\text { inesperadas. }\end{array}$ \\
\hline & Resolução de impasses & Resolve os impasses entre subordinados e outras pessoas. \\
\hline \multirow{3}{*}{ Alocador de Recursos } & $\begin{array}{l}\text { Programação de } \\
\text { compromissos }\end{array}$ & Agenda compromissos pessoais e dos subordinados. \\
\hline & Avaliação de orçamentos & $\begin{array}{l}\text { Decide sobre investimentos da empresa (analisa e seleciona projetos que } \\
\text { demandem aplicação de recursos financeiros). }\end{array}$ \\
\hline & Alocação de recursos & $\begin{array}{l}\text { Aloca os recursos financeiros, materia is e físicos, a fim de maximizar a sua } \\
\text { efic iência. }\end{array}$ \\
\hline \multirow{3}{*}{ Negociador } & $\begin{array}{l}\text { Negociação de } \\
\text { cooperação }\end{array}$ & Persuade outras pessoas a cooperarem com projetos da empresa. \\
\hline & Negociação de acordos & Negocia acordos com entidades de classe, governamentais e jurídicas. \\
\hline & Negociação de transações & $\begin{array}{l}\text { Negocia a comercialização de produtos e serviços ou acordos com outras } \\
\text { empresas. }\end{array}$ \\
\hline
\end{tabular}




\subsubsection{Modelo de Gestão}

Vinte anos após a publicação dos seus primeiros trabalhos (1971 e 1973), Mintzberg (1994, 1997, 2010) revisa seu modelo da abordagem pelos papéis ao conduzir novos estudos observando 29 administradores por um dia. O autor (MINTZBERG, 2010, p. 56) coloca sua insatisfação ao descrever o modelo como mais uma "lista de papéis desempenhados pelos administradores do que um modelo interativo" e busca evidenciar objetivamente a variedade de maneiras como as atividades gerenciais são praticadas.

Para Mintzberg (1994), embora seja visto de forma integrada, o trabalho do administrador varia de acordo com as demandas de cada cargo e a forma como cada ocupante aborda suas atividades. O que está próximo do modelo das Demandas, Restrições e Escolhas de Stewart (1982), a ser desenvolvido posteriormente neste trabalho.

De acordo com o autor (MINTZBERG, 1994), diferentes administradores enfatizam diferentes aspectos de variadas maneiras, de acordo com seu estilo:

- Conceitual - foco no desenvolvimento de modelos e estruturas;

- Administrativo - preocupação principal com o controle;

- Interpessoal - liderando internamente e promovendo ligações com aspectos externos da empresa; e

- Ativo - concentração principal nas ações tangíveis, concretas.

No centro do modelo de gestão há um núcleo onde está o administrador com seus valores, experiências, conhecimentos e competências, conforme Figura 2.2. Eles serão a base para administrador criar um sistema composto dos objetivos do seu trabalho, a perspectiva do que precisa ser feito e as estratégias a serem adotadas para sua execução. O resultado será sua agenda de trabalho e realizações (MINTZBERG, 1994).

Este núcleo se relaciona em três níveis com o contexto onde o administrador atuará, o que pode ocorrer dentro ou fora da sua unidade ou até mesmo fora da organização. 


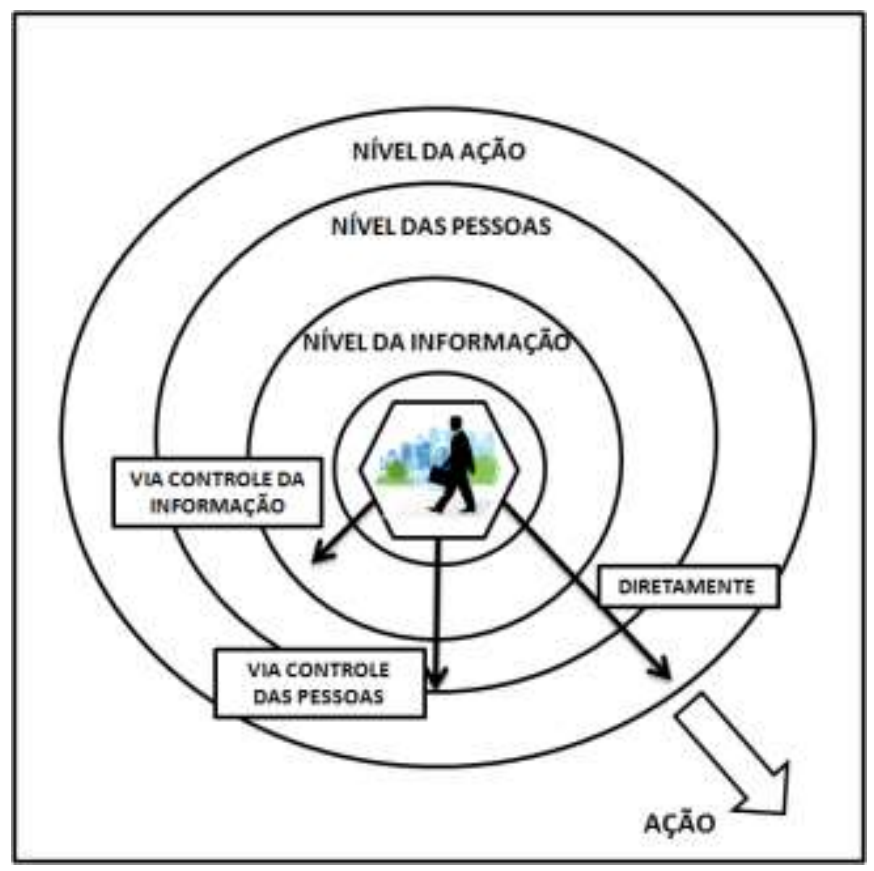

Figura 2.2: Modelo de Gestão

Fonte: Adaptado de Mintzberg (1994)

O autor recorre novamente a abordagem dos papéis, sendo dois deles desempenhados no nível informacional, dois no pessoal e um no nível da ação:

Informacional - processando as informações para conduzir as pessoas para a ação:

- Comunicador - busca e recebe informações para compartilhar com outros, tanto internamente como disseminador ou externamente como porta-voz.

- Controlador - usa as informações para controlar o trabalho dos outros, seja dando diretrizes específicas, desenhando uma estrutura organizacional (atribuição de funções e tarefas especializadas) ou desenvolvendo e aplicando os procedimentos formalmente constituídos (orçamentos, por exemplo).

Pessoal - atuando em conjunto com as pessoas:

- Líder - encorajando as pessoas para a tomada de decisão, ora focado no individuo (orientando e recompensando), no grupo (condução de equipes e solução de conflitos) ou em toda a empresa pela construção e valoração da cultura organizacional.

- Contato - com foco nas pessoas externas da sua área para a montagem de uma rede de relacionamentos inter e intra-organizacional para solução de assuntos sob sua influência e interesse (interno e externo).

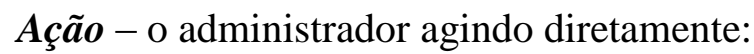


- Executor - supervisão das ações que estão sendo desenvolvidas como projetos de mudança organizacional, gerenciamento de distúrbios e negociação de acordos externos (contratos com clientes, por exemplo).

O administrador assumirá os papéis a partir daqueles que lhe são particularmente favoráveis (preferíveis), decidirá de que forma irá desempenhá-los conforme a necessidade e os tipos de relacionamento existente entre os papéis.

Em 2010, Mintzberg retoma o tema do trabalho do administrador e seu modelo desenvolvido em 1994, todavia, denominando-o de Modelo de Gestão. De acordo com suas palavras (2010, p.59), com o propósito de “[...] oferecer ao leitor um local em que o todo da gestão pudesse ser visto de uma vez só, de modo abrangente, coerente e interativo [...]”.

\subsubsection{Estudos Empíricos Utilizando o Modelo dos Papéis}

Mintzberg (1971, 1973) com seu modelo teórico dos papéis representou um marco no estudo da natureza do trabalho do administrador e, possivelmente, a maior comprovação desse fato esteja na qualidade e quantidade de trabalhos realizados desde então (CARROLL; GILLEN, 1987; LAMOND, 2004).

Por meio de sete estudos selecionados (MECH, 1997; GOTTSCHALK, 2002; JACKSON; PETERSON, 2004; TONELLI, 2005; LAITINEN, 2009; FLÓREN; TELL, 2009; ANDERSSON; FLÓREN, 2009) busca-se oferecer mais uma demonstração do vigor, atemporalidade, versatilidade, consistência e permeabilidade do modelo, por meio da pluralidade de contextos, métodos, amostras e técnicas de pesquisa utilizadas e exploradas nos trabalhos pelos autores:

- Versatilidade de objetivos, tendo em comum o tema a natureza do trabalho do administrador: o comportamento do administrador e o desempenho da empresa; similaridades ou diferenças no conteúdo e características do trabalho; a ênfase dada aos papéis; a relação entre fatores contextuais e pessoais; o trabalho e a vida pessoal.

- Flexibilidade com aplicação direta do modelo dos papéis ou combinação com outros específicos para a realidade organizacional. Bem como, a comparação, por meio de revisão teórica entre diferentes estudos, que usaram a abordagem dos papéis de Mintzberg; 
- Amplitude metodológica: uso de métodos qualitativos e quantitativos de pesquisa, aplicados com diferentes técnicas de coleta de dados: observação estruturada, entrevista, grupos de discussão, aplicação de questionário; e

- Riqueza amostral: homens e mulheres com diferentes perfis pessoais, profissionais e origens: Noruega, Suécia, Brasil, Finlândia e Estados Unidos.

- Permeabilidade nos contextos organizacionais: porte, localização, tipo de indústria (educação, tecnologia da informação, manufatura, serviços etc.), ambiente competitivo, foco mercadológico (doméstico ou externo), níveis de desempenho.

\subsubsection{Críticas ao Modelo da Abordagem dos Papéis}

Ainda que vários estudos empíricos tenham utilizado o modelo dos papéis de Mintzberg (CARROLL; GILLEN, 1987), o que prova sua ampla aceitação pelo meio acadêmico, não significa necessariamente que o modelo não tenha recebido por várias ocasiões e de diferentes formas, críticas. Incluindo do próprio Mintzberg (2010).

Estas críticas, feitas diretamente ou a partir da análise de estudos empíricos que usaram o modelo, abordam questões metodológicas, a validação dos resultados e as conseqüentes teorizações formuladas por Mintzberg (1971, 1973). Elas podem ser sintetizadas em duas diferentes abordagens:

a) Metodológica (STEWART, 1982; MARTINKO; GARDNER, 1985; CARROLL; GILLEN, 1987; LAMOND, 2003; GOTTSCHALK, 2002; TONELLI, 2005):

- Alguns estudos que validaram o modelo podem ser questionáveis porque as categorias dos papéis são muito amplas e ambíguas, possibilitando da parte dos respondentes dúvidas de interpretação, particularização ou até mesmo direcionamento das suas respostas;

- O perfil quantitativo e qualitativo da amostra usada é frágil porque se sabe que os pesquisados (executivo-chefe) não representam administradores típicos, o que não permitiria generalizações dos seus resultados;

- Em grande parte, a atividade do administrador é feita de forma intelectual (trabalho mental) e a observação estruturada tem suas limitações para permitir a compreensão do verdadeiro sentido e propósito da atividade; 
- A impossibilidade do pesquisador de acesso completo aos meios de comunicação (conversas telefônicas) e informações confidenciais, eventos que ocorram fora do horário da pesquisa (fim de semana, após o expediente), acompanhamento de viagens e reuniões externas; e

- Os possíveis efeitos da presença do observador sobre ambiente, inibindo ou estimulando o pesquisador e demais participantes para atitudes incomuns.

b) Resultados e teorizações (STEWART, 1982; CARROLL; GILLEN, 1987; WILLMOTT, 1987; LAMOND, 2003; LUTHANS et al., 1985; SNYDER; GLUECK, 1980; MARTINKO; GARDNER, 1985):

- Nem todo trabalho do administrador pode ser caracterizado pelo seu ritmo intenso, assim como pela sua brevidade, variedade e fragmentação; em alguns casos, são escolhas do administrador;

- Há sobreposição muito grande entre alguns papéis para serem considerados separadamente e a inexistência de uma relação entre eles e a eficácia organizacional;

- O trabalho do administrador é colocado em termos de atividades distintas e ignora sua realidade política, desconsiderando a natureza social e institucional de seu contexto;

- As marcantes similaridades entre as atividades desenvolvidas pelos administradores são duvidosas na medida em que há expressivas variações entre as proporções de tempo dedicadas para atividades no escritório (entre $16 \%$ e $38 \%$ ) e reuniões agendadas $(38 \%$ e $75 \%)$ e

- Mintzberg não observou os administradores executando seu trabalho de forma planejada, diferentemente daquilo que alguns estudos constataram. Também, nem todos eles demonstram preferência por contatos verbais e gastam a maior parte do seu tempo em reuniões agendadas. 


\section{4 - Contribuição de Stewart}

Rosemary Stewart produziu um relevante conjunto de trabalhos de pesquisa que se estenderam da década de 1960 até a primeira década do século XXI, colocando-a em posição de destaque no estudo do trabalho do administrador. Segundo Mintzberg (2010, p. 120), “[...] a maior autora de pesquisas sobre gestão [...]".

Mesmo após sua aposentadoria oficial, Stewart fez uma leitura realista e atemporal do estudo do trabalho do administrador admitindo que o tema nunca fosse um modismo, pois "modismos são passageiros, mas uma área de pesquisa sem modismos tem longa vida porque não corre o risco de sair de moda" (STEWART, 2008, p.49).

Demonstrando sua preocupação com as constantes mudanças que transformam ou interferem no trabalho do administrador, explorou temas de variados interesse para distintos públicos como a cultura organizacional, fenômenos de grupos, culturas nacionais e o impacto da tecnologia (LOWE, 2003).

Preferiu a abordagem qualitativa nos seus estudos, embora reconhecesse que os métodos quantitativos pudessem parecer mais científicos. Assim, aplicou um conjunto variado e inovador de métodos de pesquisa utilizando-se de entrevistas, diários, observações estruturadas, grupos de discussão, estudos de caso e teoria fundamentada em dados. Stewart (2008, p.52) entendia que "cada estudo produz resultados inesperados o que pode ser comprovado com outros estudos e que, às vezes, as explicações para as descobertas tornam-se mais claras em estudos posteriores".

Rosemary Stewart foi também pragmática no seu trabalho dando ênfase nas orientações práticas em seus estudos (aplicações em treinamento, desenvolvimento e melhorias no ambiente empresarial), servindo de inspiração para estudantes, pesquisadores e administradores (LOWE, 2003).

\subsubsection{Modelo das Demandas, Restrições e Escolhas}

Diversas pesquisas empíricas (CARLSON, 1951; MINTZBERG, 1973, 2010; STEWART, 1998; HALES, 2005; TENGBLAD, 2003) demonstraram as similaridades existentes no trabalho do administrador (características - o que fazem). Contudo, há também diferenças (HAMPTON, 1990) que podem ser justificadas pela natureza distintiva de cada 
trabalho: porte da empresa, funções executadas, tipo de negócio, pessoas envolvidas e grau de exposição do cargo (STEWART, 1998).

Mas como explicar que administradores submetidos ao mesmo emprego, sob as mesmas circunstâncias e executando tarefas muito parecidas possam ter resultados completamente diferentes? Neste caso, Stewart (1998, p.13) afirma categoricamente: “Os administradores executam seus trabalhos de forma diferente porque o vêem de forma diferente.".

Assim, talvez uma das mais significativas contribuições do trabalho de Stewart esteja no seu modelo das Demandas, Restrições e Escolhas, desenvolvido com a finalidade de contemplar a variedade e flexibilidade do trabalho e comportamento do administrador. Ou seja, como os administradores, em trabalhos semelhantes, poderiam diferir na maneira como o viam e executavam-no (STEWART, 1982).

As escolhas são limitadas pelas demandas e restrições e o conceito básico está fundamentado nas três grandes categorias (STEWART, 1982; HAMPTON, 1990):

- As Demandas formam a parte do núcleo central do trabalho do administrador. São muitas atividades que qualquer um ocupando aquela posição deve cumprir porque está na sua descrição de cargo ou porque seu chefe entende ser importante. Mas Demanda é um termo restrito: somente aquilo que deve ser feito;

- As Restrições são fatores, internos ou externos, tangíveis ou não, que limitam o trabalho que o ocupante do cargo pode fazer. Por exemplo: restrições legais, limitações tecnológicas, localização física, restrições organizacionais (amplitude na qual a unidade de trabalho do administrador é definida); atitudes de outras pessoas sobre mudanças nos sistemas, procedimentos, pagamentos, organização e condições; mudanças de bens e serviços produzidos; trabalho fora da unidade; e

- As Escolhas são atividades que o ocupante do cargo pode executar, mas não é obrigado a fazê-lo. São oportunidades que o administrador tem para agir diferentemente dos outros, ainda que na mesma função, nível ou cargo. São alternativas dentro da área definida (enfatizar certos aspectos do trabalho, selecionar algumas tarefas e ignorar ou delegar outras), na fronteira administrativa (negociar com pessoas de fora da unidade ou empresa que podem afetá-la) ou alternativas de mudar a área de trabalho (mudar o domínio da unidade, desenvolver o domínio pessoal, tornar-se um especialista, compartilhar o trabalho com outras pessoas). 


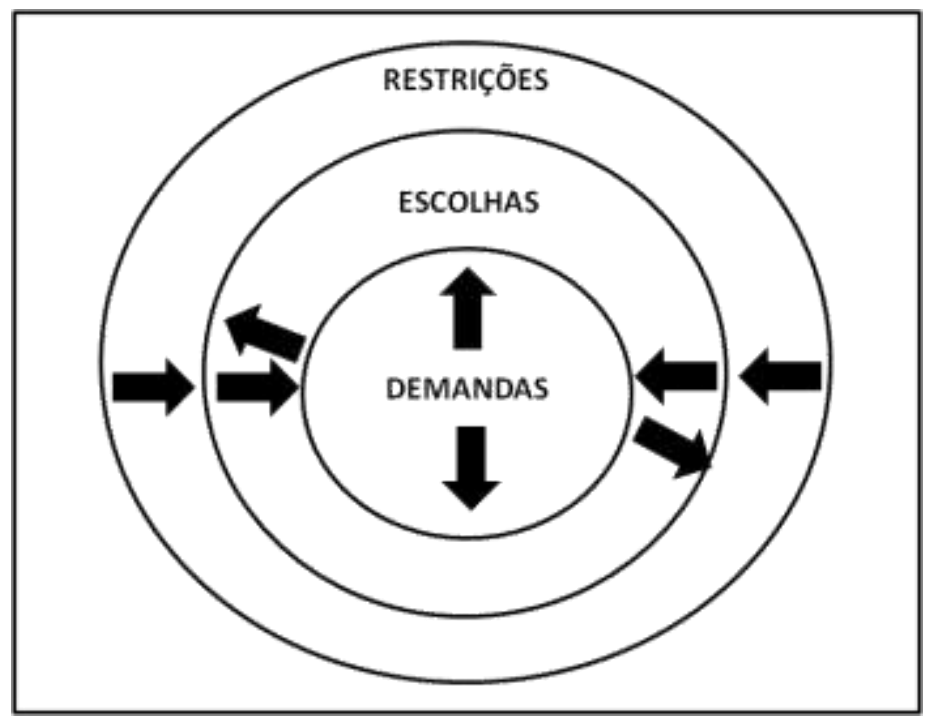

Figura 2.3: Modelo das Demandas, Restrições e Escolhas. Fonte: Hampton (1990, p. 13)

A Figura 2.3 mostra o modelo como um círculo concêntrico de três anéis: no núcleo estão as Demandas; o anel periférico contém as Restrições; no intermediário, estão as Escolhas. Na prática, os administradores que se sentem mais passivos podem ver demandas e restrições como imutáveis. Por outro lado, aqueles mais dinâmicos, que se sentem mais autônomos e capazes, podem expandir a área de escolha criativamente, diminuindo o espaço entre as demandas e restrições (HAMPTON, 1990).

As pessoas comumente têm suas próprias demandas (coisas que acreditam que precisam ser feitas), restrições (crenças, medos ou falta de conhecimento e habilidade) e suas próprias percepções das escolhas (STEWART, 1982). Estas três categorias são dinâmicas e sofrem mudanças com decorrer do tempo, tanto pelas circunstâncias, o que considera as expectativas daqueles com quem o administrador trabalha, como o que o administrador faz para ajustar seu trabalho e por quanto tempo está executando-o (STEWART, 2008).

No entanto, o modelo foi alvo de críticas pela dificuldade de fazer claras distinções entre restrições e demandas e pela sua subjetividade na identificação das diferenças entre as atividades do administrador, fato inerente ao uso de abordagens qualitativas na pesquisa empírica (KROECK, 2003). 


\subsubsection{Implicações do Modelo para a Pesquisa}

Conforme visto anteriormente, o modelo das demandas, restrições e escolhas oferece um caminho para pensar a respeito das diferenças nos trabalhos dos administradores e também, como eles o vêem e desenvolvem-no (STEWART, 1982, 2008).

Pela sua estrutura teórica, baseado em três categorias, é possível levantar informações objetivas sobre as características particulares das demandas (responsabilidades, atribuições) e restrições (internas e externas), constituintes da atividade do administrador e identificar suas escolhas, compreendendo as variações em seu conteúdo. O que possibilita ampliar o alcance da pesquisa empírica para além do modelo da abordagem dos papéis de Mintzberg (1973, 1994, 2010). 


\section{ESPECIFICIDADES DE GESTÃO DA PEQUENA EMPRESA}

A primeira seção do capítulo trata da importância social, econômica, mercadológica e política que justifica o estudo da pequena empresa, fato que ocorre não só no Brasil como também há muito anos em vários países do mundo.

Porém, diante de sua heterogeneidade, classificar o que é uma pequena empresa requer o uso de dois tipos de critérios: quantitativos (também conhecidos por convencionais ou econômicos) que utilizam métricas como vendas, quantidade de empregos etc.; e qualitativos, mais sintonizados com estágios de gestão, especificidades organizacionais e atitudes e estilos de seus dirigentes. Portanto, um enfoque mais interno e muitas vezes amplo e subjetivo.

Após ver na segunda seção os critérios de classificação das pequenas empresas, o capítulo é encerrado com a apresentação das características da pequena empresa, utilizando como abordagem o modelo desenvolvido pelo Grupo de Estudos Organizacionais da Pequena Empresa - DEP/EESC-USP (GEOPE), a partir de suas especificidades: o Dirigente, a Organização, o Contexto e o Processo Estratégico. Em especial sobre o dirigente, são mostrados vários estudos e pesquisas empíricas da natureza do seu trabalho: suas características (o que faz; como aloca seu tempo; com quem interage e se comunica) e seu conteúdo (papéis desempenhados).

\subsection{A Importância do Estudo da Pequena Empresa}

Quando o assunto é pequena empresa, uma pergunta surge naturalmente: o que justificaria estudá-las, uma vez que registram, de acordo com as estatísticas, elevados índices de mortalidade e representam apenas $2,7 \%$ da parcela das exportações brasileiras (SEBRAENA / Funcex, 2006)?

Visto somente por este ângulo, talvez realmente não fosse justificável, economicamente, estudar a pequena empresa. Contudo, conforme pode ser observado no Quadro 3.1, constata-se que a participação das micro e pequenas empresas na economia brasileira é relevante, em especial no número de estabelecimentos, empregados com carteira, faturamento e PIB: 


\begin{tabular}{|c|c|c|}
\hline Variável & Participação & Fonte / Ano \\
\hline $\begin{array}{c}\text { Número de } \\
\text { estabelecimentos }\end{array}$ & $98 \%$ & SEBRAE-SP (2006) \\
\hline $\begin{array}{c}\text { Empregados "com } \\
\text { carteira" }\end{array}$ & $53 \%$ & RAIS / MTE (2004) \\
\hline $\begin{array}{c}\text { Faturamento } \\
\text { Produto Interno Bruto } \\
\text { (PIB) }\end{array}$ & $28 \%$ & SEBRAE-NA (2000) \\
\hline
\end{tabular}

Quadro 3.1: Participação das Micro e Pequenas Empresas Fonte: Adaptado de SEBRAE (2010)

Também em outros países, é expressiva a importância do papel social e econômico das pequenas empresas visto que são a maioria dos estabelecimentos nos países industrializados (entre 86 e 99\%) e contribuem de maneira expressiva com emprego de 55\% da mão de obra no Reino Unido, 60\% na Alemanha e 63\% na França (FULLER, 2003).

No ponto de vista macroeconômico, as pequenas empresas participam com importância na formação do produto nacional, geração de renda e arrecadação de impostos. E, de forma mais relevante, elas contribuem na preservação da estabilidade e dinâmica da economia de mercado, o que permite a desconcentração das atividades e maior geração e distribuição regional de empregos.

Outros autores destacam em seus trabalhos razões pelas quais a importância das pequenas empresas justifica seu estudo. Julien (1997), Fuller (2003), Beaver e Jennings (2000) e Gray e Mabey (2005) apontam o papel vital das pequenas empresas na economia como provedoras, além de empregos, também de:

- Novas ideias, produtos e serviços;

- Sustentabilidade na multiplicação e renovação dos negócios para o crescimento da economia;

- Suporte para grandes empresas como fornecedores que viabilizam a flexibilidade dos processos produtivos;

- Diversidade de usos e rápida exploração de novas tecnologias em nichos de mercado. 
Como afirmou Fuller (2003, p.317) na sua visão de futuro para as pequenas empresas, o horizonte favorece a continuidade delas porque têm um importante e crescente papel. O autor sustenta sua posição com a seguinte afirmação:

As pequenas empresas são requeridas hoje em dia pela sociedade por sua geração de empregos e alternativa de carreira. Elas são necessitadas pelos cidadãos-consumidores que demandam serviços e escolhas que exigem fornecedores orientados para nichos de mercado. Elas são necessárias como veículos para atividades empreendedoras individuais no contexto econômico, sejam como artesãos, inovadores, especialistas, empreendedores ou proprietários de empresas familiares.

\subsection{Critérios para Classificação da Pequena Empresa}

Dadas sua heterogeneidade e volatilidade intrínsecas, não é tarefa simples definir rigorosa e pacificamente o que pode ser considerado uma pequena empresa. Beaver e Jennings (2000) afirmaram que as pequenas e médias empresas são mais fáceis de descrever do que definir. Assim, emerge a pergunta: como definir o que é uma pequena empresa?

O enquadramento e a classificação estão sujeitas a controvérsias tanto para pesquisadores, governos e instituições privadas, ocorrendo algumas vezes o uso de critérios arbitrários. Na busca de consenso e resultados práticos, são adotados critérios quantitativos ou qualitativos, resumidos a partir da visão de vários autores (DUTRA; GUAGLIARDI, 1984; D'AMBOISE; MULDOWNEY, 1988; LEONE, 1991, 1999; JULIEN, 1997).

\subsubsection{Critérios Quantitativos}

Denominados também de convencionais ou econômicos, se baseiam em valores numéricos, conforme resumidos no Quadro 3.2: 


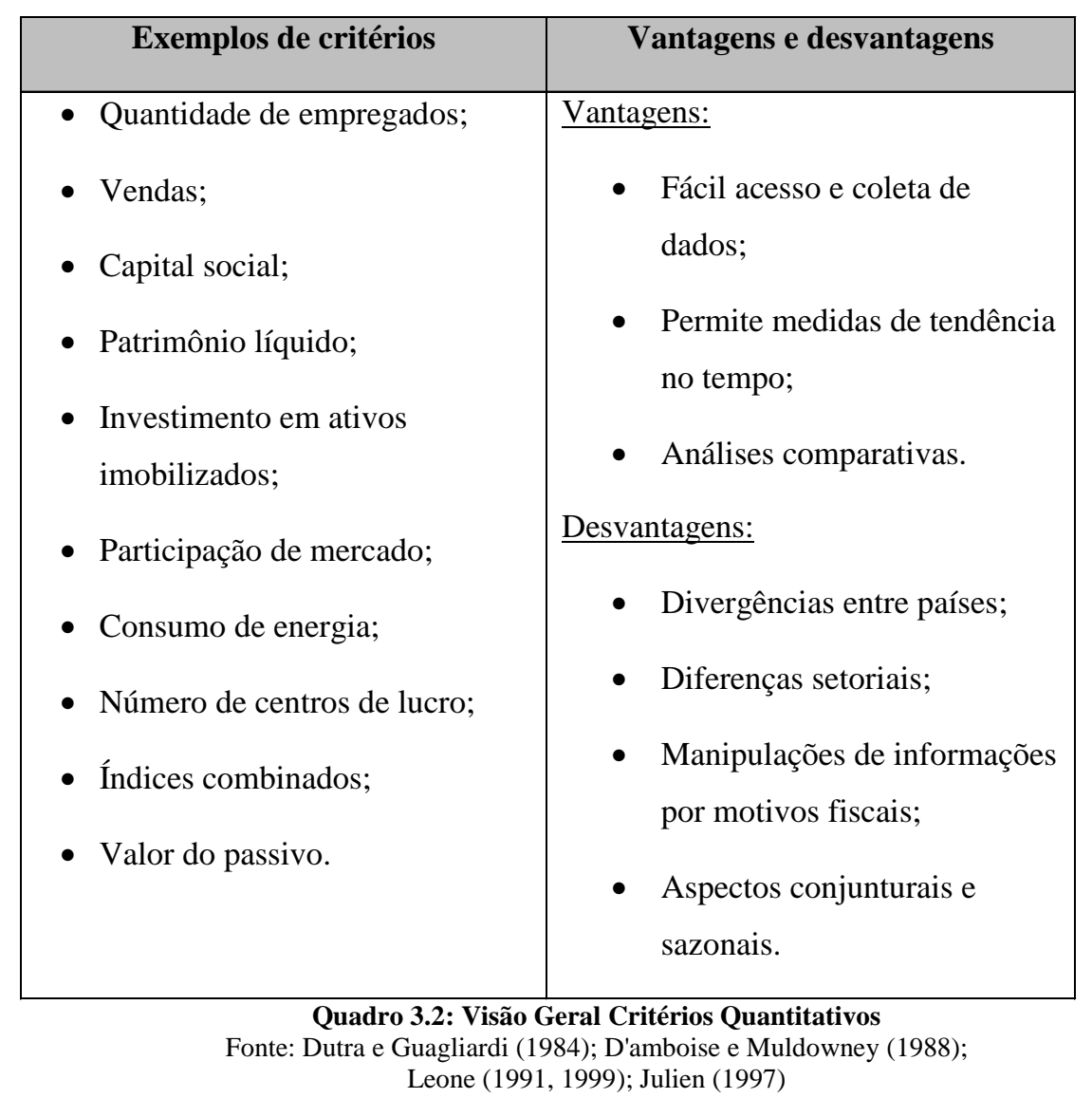

Podem-se mencionar, a título de exemplo de critérios quantitativos, aqueles adotados no Brasil pelo Instituto Brasileiro de Geografia e Estatística (IBGE) e pelo Serviço Brasileiro de Apoio às Micro e Pequenas Empresas (SEBRAE) para a classificação das empresas de acordo com o valor das receitas (Quadro 3.3) e número de empregados (Quadro 3.4):

\begin{tabular}{|c|c|}
\hline Critérios & Valor da Receita Bruta Anual \\
\hline Lei no 9.841 de 05/10/1999 & Até 244 mil reais \\
Microempresas & De 244 mil reais a 1,2 milhão de reais \\
Empresas de pequeno porte & Até 400 mil dólares \\
\hline BNDES (critério dos países do & dólares \\
MERCOSUL para fins creditícios) & De 400 mil dólares a 3,5 milhões de \\
Empresas de pequeno porte & doempresas
\end{tabular}

Quadro 3.3: Porte segundo a Receita Bruta Anual Fonte: Adaptado de IBGE (2003) 


\begin{tabular}{|c|c|c|}
\hline Porte/setor & Indústria & Comércio e serviços \\
\hline Microempresas & Até 19 & Até 9 empregados \\
\hline Empresas de Pequeno Porte & De 20 a 99 & De 10 a 49 \\
\hline Médias & De 100 a 499 & De 50 a 99 \\
\hline Grandes & 500 ou mais & 100 ou mais \\
\hline
\end{tabular}

Quadro 3.4: Critérios de classificação da Pequena Empresa Fonte: Adaptado de SEBRAE (2006)

\subsubsection{Critérios Qualitativos}

Não se baseiam em valores numéricos, mas sincronizados com os estilos de gestão, perfil e atitudes dos dirigentes da empresa. Apresentam maior enfoque nos aspectos internos com abordagem gerencial da organização, demonstrando a complexidade na definição dos tipos e a consequente heterogeneidade das pequenas empresas. O Quadro 3.5 apresenta exemplos de critérios qualitativos:

\begin{tabular}{|c|c|}
\hline Exemplos de critérios & Vantagens e desvantagens \\
\hline $\begin{array}{l}\text { - Tipo de origem ou propriedade; } \\
\text { - Estratégia seguida ou potencial da } \\
\text { empresa; } \\
\text { - Evolução, grau de desenvolvimento ou } \\
\text { organização; } \\
\text { - Setor ou tipo de mercado de atuação; } \\
\text { - Estrutura organizacional e de capital; } \\
\text { - Nível de especialização da administração e } \\
\text { mão de obra; } \\
\text { - Escala e complexidade da tecnologia de } \\
\text { produção; } \\
\text { - Grau de relacionamento e formalidade } \\
\text { entre proprietários empregados, clientes e } \\
\text { - } \text { fornecedores; } \\
\text { - } \text { Dificuldade de acesso ao crédito; } \\
\text { - Integração com a comunidade local. }\end{array}$ & $\begin{array}{l}\text { Vantagens: } \\
\text { - } \quad \text { Considera divergências entre } \\
\text { países, diferenças setoriais e } \\
\text { aspectos conjunturais e sazonais; } \\
\text { - } \begin{array}{l}\text { Menor grau de exposição às } \\
\text { manipulações de informações por } \\
\text { motivos fiscais. }\end{array} \\
\text { Desvantagens: } \\
\text { - } \\
\text { Acesso mais difícil para coleta de } \\
\text { dados; } \\
\text { Limita possibilidade de medidas de } \\
\text { tendência no tempo e análises } \\
\text { comparativas. }\end{array}$ \\
\hline
\end{tabular}

Quadro 3.5: Visão Geral Critérios Qualitativos de classificação da pequena empresa Fonte: Dutra e Guagliardi (1984); D'amboise e Muldowney (1988);

Leone (1991, 1999); Julien (1997) 
Todavia, isoladamente, os dois critérios são insuficientes para classificação e tipificação de uma pequena empresa, cabendo a aplicação de critérios mistos, resultantes da combinação de aspectos quantitativos e qualitativos, como solução para a dificuldade de definir e tipificar o que é uma pequena empresa.

\subsection{Características da Pequena Empresa}

Vários autores caracterizaram a pequena empresa em seus trabalhos com diferentes fins: proposição de critérios homogeneizadores de classificação; formulação de modelos teóricos; estudo da cultura empresarial; desenvolvimento gerencial; classificação dos problemas mais comuns nas pequenas empresas; especificidades organizacionais, entre outros (LEONE, 1999; D’AMBOISE; MULDOWNEY, 1988; GRAY; MABEY, 2005; BEAVER; JENNINGS, 2000; JULIEN, 1997; GIBB, 2000; HAUGH; McKEE, 2004; HUANG; BROWN, 1999; TORRÈS; JULIEN, 2005).

Para seus estudos, capacitações e consultorias, o IBGE (2003) e o SEBRAE (2006) seguem suas próprias definições sobre as principais características das micro e pequenas no Brasil, conforme resumido no Quadro 3.6, a saber:

\begin{tabular}{|c|c|}
\hline SEBRAE & IBGE \\
\hline $\begin{array}{l}\text { - Produtos e serviços de baixo preço } \\
\text { unitário; } \\
\text { - Predominam vendas ao consumidor } \\
\text { final; } \\
\text { - Atendem necessidades básicas da } \\
\text { população: alimentos e bebidas, } \\
\text { vestuário, calçados, móveis, } \\
\text { moradia (construção e reforma); } \\
\text { - Escalas de produção muito baixas: } \\
\text { capital, insumos, materiais, mão-de- } \\
\text { obra, etc.; e } \\
\text { - Tecnologia de domínio público. }\end{array}$ & $\begin{array}{l}\text { - } \text { Baixa intensidade de capital; } \\
\text { - Altas taxas de natalidade e mortalidade } \\
\text { - Forte presença de proprietários, sócios e membros } \\
\text { da família como mão de obra ocupada nos negócios; } \\
\text { - Poder decisório centralizado; } \\
\text { - Estreito vínculo entre os proprietários e as } \\
\text { empresas, não se distinguindo, principalmente em } \\
\text { termos contábeis e financeiros, pessoa física e } \\
\text { jurídica; } \\
\text { - Registros contábeis pouco adequados; } \\
\text { - Contratação direta de mão de obra; } \\
\text { - Utilização de mão-de-obra não qualificada ou semi- } \\
\text { - } \text { - Bualificada; } \\
\text { - Maixo investimento em inovação tecnológica; } \\
\text { capital de giro; e } \\
\text { - Relação de complementaridade e subordinação com } \\
\text { as empresas de grande porte. }\end{array}$ \\
\hline
\end{tabular}


Para fins de organização, síntese e análise das características da pequena empresa será adotado o modelo desenvolvido e aplicado pelos pesquisadores do GEOPE em seus trabalhos acadêmicos. Ele é um esforço de caracterizar a pequena empresa a partir de suas "especificidades de gestão", portanto, fortemente fundamentado em correntes organizacionais.

O modelo aborda a pequena empresa a partir de quatro perspectivas (Figura 3.1):

- A Organização - divisão do trabalho e estrutura, sistemas de comunicação e informação, especialização, disponibilidade de recursos e sua alocação;

- O Contexto - ambiente externo e grau de influência e controle;

- O Processo Estratégico - grau de deliberação ou emersão da estratégia; grau de formalização ou informalidade no processo de execução da estratégia; e

- O Dirigente - aspectos comportamentais, relacionados com as características pessoais do dirigente.

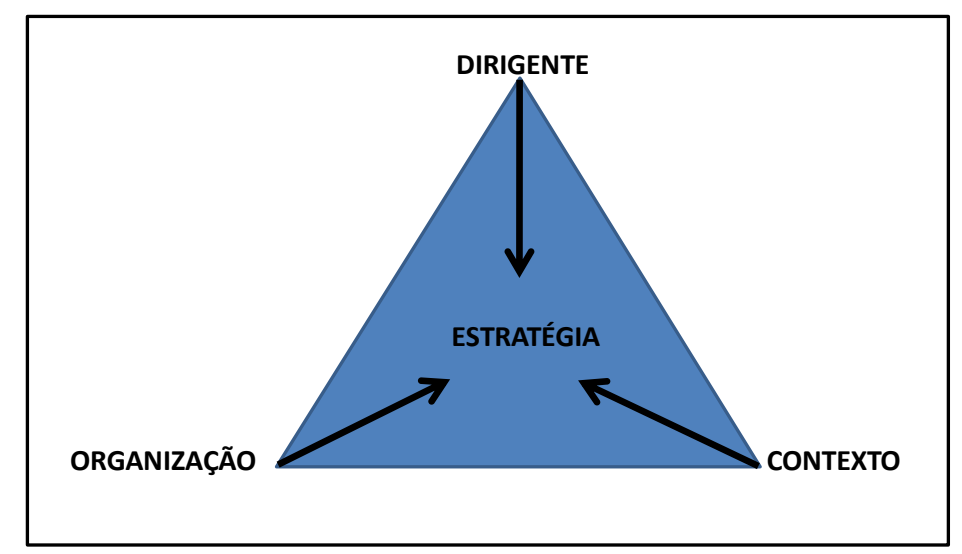

Figura 3.1: Modelo GEOPE

Fonte: Adaptado de Terence (2009)

\subsubsection{A Organização}

As pequenas empresas, na perspectiva da sua organização podem ser caracterizadas pela pouca especialização funcional, muitas vezes com sobreposição de atividades, tarefas e responsabilidades, levando a certa ambiguidade de papéis. Há informalidade nas comunicações e nos relacionamentos internos e externos, baseados fortemente no contato direto. A estrutura organizacional é simplificada, orgânica, horizontal com poucos níveis hierárquicos, com forte centralização pela sua direção, em geral, mais multifuncional que nas grandes empresas. Observa-se também a escassez de recursos e a dificuldade de atrair ou reter 
profissionais de nível gerencial para seus quadros (JULIEN, 1997; LEONE, 1999; D' AMBOISE; MULDOWNEY, 1988; GIBB, 2000; HAUGH; McKEE, 2004; GRAY; MABEY, 2005; BEAVER; JENNINGS, 2000; HUANG; BROWN, 1999).

\subsubsection{O Contexto}

A pequena empresa é muito vulnerável e detém pouco, ou praticamente nenhum, controle sobre o ambiente extra-organizacional. Assim, sua vantagem competitiva advém exatamente da sua grande flexibilidade e capacidade de adaptação ao ambiente e da gestão dos escassos recursos disponíveis (LEONE, 1999; D’AMBOISE; MULDOWNEY, 1988; GRAY; MABEY, 2005; BEAVER; JENNINGS, 2000).

Diante da pouca, ou nenhuma, influência da pequena empresa em relação ao ambiente externo, ela se vê diante da necessidade ocupar posição estratégica que possibilite sua sobrevivência. Neste sentido, Souza e Mazzali (2008) identificaram quatro possíveis trajetórias de sua inserção na estrutura industrial:

- Pequenas empresas em mercados competitivos: a estratégia competitiva está baseada no menor custo relativo de mão de obra, comparativamente às grandes empresas. Dessa forma, ela disputa espaço em mercados ainda pouco oligopolizados e com acentuada concorrência de preços;

- Pequenas empresas independentes em estruturas industriais dinâmicas: o dirigente, com sua "perspicácia empresarial", percebe e reúne elementos necessários para explorar "nichos" de mercado que se formam a partir de oportunidades em setores na fronteira tecnológica, não exploradas pelas grandes empresas;

- Pequenas empresas organizadas em redes sem a liderança de uma grande empresa: a estratégia é o desenvolvimento de ações conjuntas e coordenadas para ganhos de vantagem. Nesse caso, são parte integrante em aglomerações setoriais de empresas sem a liderança explícita de nenhuma de suas participantes; e

- Pequenas empresas integrantes de redes comandadas por grandes empresas: há subordinação à grande empresa, como elemento complementar a esta. Trata-se da inserção da pequena empresa em redes de relações (subcontratações), comandadas por uma grande empresa. 


\subsubsection{O Processo Estratégico}

O processo estratégico nas pequenas empresas caracteriza-se basicamente pela informalidade e o uso da intuição na sua concepção com pouca distinção entre formulação e implantação. O foco está na sobrevivência e melhoria de desempenho, basicamente dirigida para resultados práticos como a satisfação dos clientes e retenção de funcionários com ênfase nas práticas de planejamento que tragam resultados no curto prazo. (JULIEN, 1997; LEONE, 1999; GIBB, 2000; GRAY; MABEY, 2005; BEAVER; JENNINGS, 2000).

Portanto, o dirigente da pequena empresa não tem tempo para atividades estratégicas de longo prazo porque muito tempo é consumido com o acompanhamento das tarefas operacionais do cotidiano e as atividades não planejadas da empresa (ANDERSSON; FLORÉN, 2009).

\subsubsection{O Dirigente}

Estudos sobre a natureza do trabalho do administrador, em suas mais variadas abordagens, são bastante extensos e têm longa tradição, portanto, estão bem desenvolvidos. Contudo, a literatura sobre a pequena empresa é comparativamente escassa, insuficiente e pouco esforço tem sido feito para explorar o assunto (ANDERSSON; FLORÉN, 2008; FLORÉN, 2006). O resultado é que o conhecimento sobre o trabalho do administrador da pequena empresa é ainda muito limitado (O’GORMAN et al., 2005).

Investigar um tema novo como o trabalho do administrador da pequena empresa requer, em boa parte, estudos exploratórios de caráter usualmente indutivo. Dessa maneira, são utilizados métodos qualitativos (por exemplo, estudos de caso com observação estruturada), minuciosas revisões bibliográficas bem como, técnicas que combinam instrumentos qualitativos e quantitativos (ANDERSSON, FLORÉN, 2009; FLORÉN; TELL, 2003, 2009; FLORÉN, 2006; WAHLGRÉN, STEWART, 2003; O’GORMAN; BOURKE; MURRAY, 2005; REIJONEN, 2008).

De forma geral, pode-se observar que parte significativa desses estudos sobre o trabalho do dirigente, em particular da pequena empresa, tratam de responder as seguintes questões (HALES, 1999; FLORÉN, 2006):

- O que o dirigente faz? Os elementos substantivos do seu trabalho; 
- Como aloca o seu tempo? A distribuição entre as diferentes atividades;

- Com quem interage e se comunica? As interações e suas características;

- O que mais faz o dirigente? Os elementos informais do seu trabalho;

- Os temas que permeiam o trabalho do dirigente: que qualidades o seu trabalho tem?

Partindo-se de uma visão geral, pode-se caracterizar o dirigente da pequena empresa pela sua centralização nos processos de gestão, exercendo influência direta em toda a organização, estabelecendo intuitivamente os objetivos, metas e planos que refletem suas aspirações, personalidade, onipotência, individualismo, motivações e grau de autoritarismo. A empresa e sua pessoa se confundem, inclusive no ponto de vista de recursos e patrimônio pois, normalmente, é proprietário do capital. Seu relacionamento está baseado na confiança interpessoal, sempre próximo dos seus funcionários, enfatizando as relações informais com efeitos sobre as atividades funcionais, obrigações, tarefas e responsabilidades (JULIEN, 1997; LEONE, 1999; D’AMBOISE; MULDOWNEY, 1988; GIBB, 2000; GRAY; MABEY, 2005; HAUGH; McKEE, 2004; BEAVER; JENNINGS, 2000; ANDERSSON; FLORÉN, 2009).

Florén e Tell (2006), com o objetivo de investigar as características do trabalho do dirigente da pequena empresa, replicaram os estudos de Choran, Mintzberg e Kurke e Aldrich com seis administradores-proprietários de pequenas empresas manufatureiras suecas. $\mathrm{O}$ resultado de suas observações levou-os a concluir que os dirigentes:

- Passam próximo de $80 \%$ do seu tempo no escritório e apenas $8 \%$ na fábrica;

- Despendem quase metade do seu tempo em atividades na sua mesa de trabalho, embora frequentemente interrompidas;

- Participam de poucas reuniões agendadas e, na maioria, com mais de três participantes;

- Gastam quase metade do seu tempo diário de trabalho em encontros não agendados, em média 22 em um dia;

- Realizam, diariamente, em torno de cinco visitas às instalações de produção e muitas delas com propósitos específicos;

- Têm atividades muito fragmentadas com $78 \%$ delas durando menos de 9 minutos e apenas $2 \%$ mais de uma hora;

- Nos seus contatos verbais, $51 \%$ são mantidos com seus subordinados, $10 \%$ com clientes, $28 \%$ com fornecedores e $11 \%$ com outras partes; 
- Agem por sua própria iniciativa na maior parte das vezes.

Os autores ressaltam alguns pontos importantes para serem considerados nas análises inter e intra-estudos (comparativamente a outros trabalhos), pois podem interferir nos resultados. Todos eles são inerentes a heterogeneidade de qualquer grupo e abordam características intrínsecas e extrínsecas às empresas (FLORÉN; TELL, 2006):

- Perfil e concentração de clientes nas empresas pesquisadas;

- Variações significativas no grau de instrução entre os dirigentes;

- Tempo de vivência na função gerencial;

- Estrutura organizacional da empresa; e

- Aspectos e diferenciações culturais marcantes entre países.

Valendo-se da análise de outros cinco estudos de caso, Andersson e Florén (2008) afirmaram que o dirigente da pequena empresa tem uma cadeia interna de relacionamentos bastante restrita. Ao contrário de interagirem com a maior parte de seus funcionários, eles mantém contato com um pequeno grupo, o que em parte é explicado pelas raras visitas que fazem às instalações da empresa.

O’Gorman et al. (2005), também replicando o trabalho de Mintzberg, exploraram o comportamento diário de dez dirigentes-proprietários de pequenas empresas orientadas para o crescimento e compararam os resultados com estudos sobre administradores de grandes empresas, identificando similaridades e diferenças entre ambos:

\section{Similaridades no trabalho do dirigente da pequena com a grande empresa:}

- Caracterizado pela brevidade e fragmentação;

- Preferência por contatos verbais em detrimento dos escritos;

- Atividades executadas em um ritmo intenso; e

- Constante mudança de papéis e funções desempenhadas, agindo e reagindo imediatamente de acordo com as informações recebidas em tempo real.

\section{Diferenças no trabalho do dirigente da pequena com a grande empresa:}

- Menor parcela do tempo é destinada para atividades programadas, por exemplo, reuniões planejadas com antecedência; 
- A comunicação é menos formal com uso constante de contatos telefônicos e reuniões inopinadas;

- Maior gasto de tempo com atividades consideradas como não-gerenciais;

- Desempenho de forma predominante dos papéis de líder, monitor e empreendedor. O tamanho pequeno, o limitado relacionamento com agentes externos e a centralidade do dirigente da pequena empresa explicam por que papéis como disseminador, porta-voz, negociador e gerenciador de conflitos têm menor predominância.

Como parte do seu estudo, O’Gorman et al. (2005) observaram que o dirigente da pequena empresa:

- Gasta $31 \%$ do seu tempo com atividades classificadas como de gerenciamento geral do negócio e $55 \%$ para atividades funcionais consideradas centrais (25\% para marketing e vendas, $21 \%$ produção e $9 \%$ finanças); e

- Do total de dez atividades listadas, em seis os dirigentes gastam apenas $14 \%$ do seu tempo com pesquisa e desenvolvimento (5\%), engenharia aplicada (4\%), pesquisa de mercado (4\%), distribuição (1\%), pessoal $(1 \%)$ e jurídico $(0,1 \%)$.

Portanto, na visão dos autores, de forma geral, o tamanho da empresa é um importante determinante da variabilidade na natureza do trabalho do dirigente porque o pequeno porte:

- Viabiliza o grande contato interpessoal e a consequente informalidade nos padrões de comunicação;

- Reforça a característica da centralidade do dirigente da pequena empresa;

- Interfere na natureza estratégica e funcional do trabalho do dirigente que executa variados papéis, inclusive de linha, com amplitude de responsabilidades e tarefas maiores do que, comparativamente, o administrador da grande empresa.

Em boa parte, a afirmação acima está de acordo com o pensamento de Wahlgrén e Stewart (2003) de que a diferença no trabalho do proprietário-dirigente da pequena empresa em relação ao administrador empregado deve-se a três fatores principais, sendo primeiro o porte da firma e os demais a origem dos recursos básicos e a estrutura de propriedade do negócio. 
Florén (2006) descreveu, a partir da síntese de cinco estudos investigativos aplicados com observação direta do comportamento, as características básicas e qualidades da natureza do trabalho do dirigente na pequena empresa a partir da:

\section{Alocação do tempo entre as diferentes atividades, essencialmente caracterizadas pela brevidade e fragmentação:}

- O trabalho diário é longo, febril e com poucos eventos rotineiros. Não parecendo ter um padrão no nível quantitativo das atividades;

- O dirigente passa maior parte do tempo em atividades desenvolvidas no seu escritório;

- Reuniões planejadas são raras e os imprevistos são freqüentes;

- Alto grau de fragmentação no trabalho, caracterizado pelo grande número de atividades que duram menos de dois minutos; e

- Poucas atividades são completadas sem interrupção, por várias vezes promovidas pelo próprio dirigente.

\section{Interação e comunicação gerencial:}

- Gastam maior parte do tempo com subordinados diretos do que com clientes e fornecedores;

- Usam meios de comunicação informal: telefone e encontros não planejados;

- Preferem informações "não oficiais" ao invés das formais, como relatórios gerenciais;

- Pouco uso, ou nenhum, de reconhecidas ferramentas gerenciais como gráficos, organogramas, planos e orçamentos. Tampouco, técnicas administrativas de marketing, gestão de pessoas e desenvolvimento de estratégias; e

- Padrão de comunicação menos estruturada.

\section{Elementos do trabalho do dirigente na pequena empresa:}

- Variedade de papéis e funções desempenhadas durante um único dia;

- Atuação em diferentes níveis organizacionais: estratégico, tático e operacional (linha);

- Presença comum de atividades tidas como não gerenciais;

- Preferência por atividades com maior habilidade, inclinação e gosto pessoal; 
- Habilidade desenvolvida para conseguir desempenhar os diferentes papéis e tarefas com flexibilidade e rapidez de adaptação a situações e necessidades características das pequenas empresas; e

- Dificuldade para delegar por receio ou necessidade alegada de manter o controle dos negócios.

Resumindo, os dirigentes da pequena empresa agem por sua iniciativa na maior parte das vezes; suas atividades se caracterizam pelo ritmo intenso, brevidade, variedade e fragmentação; preferem contatos verbais; e atuam em diferentes níveis organizacionais.

Assim, conformando a afirmação de Florén (2006) “... o dia do gestor na pequena empresa é não-planejado, informal, febril e fragmentado. Gerenciar uma pequena empresa é ser parte de um fluxo de atividades ocasionais e não-premeditadas”. 


\section{Mítoodos ne resseurs.}

O presente capítulo está construído baseado na proposição de Creswell (2007) para a estruturação de uma pesquisa: a alegação de conhecimento, a estratégia de investigação e as técnicas de coleta e análise de dados.

No tocante a alegação de conhecimento, na segunda seção, serão tratadas as definições e a exposição das principais características do método qualitativo de pesquisa, bem como suas limitações.

A terceira seção é sobre o estudo de caso, que pode ser definido como uma estratégia de pesquisa para investigar empiricamente um fenômeno contemporâneo dentro de seu contexto da vida real - em cenários singulares, únicos - sem limites claramente definidos entre fenômeno e contexto, e sem o controle do pesquisador (YIN, 2005; STAKE, 1995; EISENHARDT, 1989). Na seção também são apresentadas suas finalidades, tipologias, o processo de seleção de casos, a questão da generalização e críticas mais recorrentes.

Uma seção é especialmente dedicada às características pessoais e o papel do pesquisador na abordagem qualitativa, visto sua importância como próprio "instrumento" de pesquisa, com sua visão de mundo tem influência direta nas suas escolhas e prioridades (STAKE, 1995).

Alinhado com a proposição de Creswell (2007), foram desenvolvidas duas seções: uma para tratar das técnicas de coleta de dados, apresentando uma visão geral dos instrumentos principais, com ênfase na observação, entrevista e análise documental. E a outra para os procedimentos de análise dos dados coletados, em especial a análise interna do caso e a análise cruzada entre casos.

A penúltima seção aborda as delimitações do estudo de campo realizado considerando número de casos, perfil das empresas e dirigentes selecionados para a pesquisa.

Por fim, mas não menos importante, o capítulo é encerrado com as considerações sobre a ética na operacionalização da pesquisa em sua atividade de campo (coleta de dados) e suas principais práticas: consentimento informado, anonimato e confidencialidade dos dados. 


\subsection{A Estruturação da Pesquisa}

Segundo Creswell (2007), uma pesquisa deve estar baseada em três questões centrais:

- Que alegação de conhecimento é feita pelo pesquisador, incluindo a perspectiva teórica?

- Que estratégias de investigação irão orientar os procedimentos de pesquisa?

- Que métodos de coleta e análise de dados serão usados?

Primeiramente, as Alegações de Conhecimento - denominadas também de paradigmas, suposições filosóficas, epistemológicas e ontológicas - significa que o pesquisador começa seu trabalho com determinadas suposições sobre como e o que irá aprender durante sua investigação. Elas podem ser classificadas, ainda de acordo com Creswell (2007), em quatro escolas de pensamento e principais elementos de cada posição:

- Pós-positivismo: o conhecimento é conjectural, a verdade absoluta nunca pode ser encontrada. A pesquisa é um processo de fazer alegações onde causas determinam os efeitos ou resultados; dados, provas e considerações racionais moldam o conhecimento, ser objetivo é um aspecto essencial da investigação. Ideias centrais: determinação, reducionismo, observação empírica, mensuração e verificação da teoria.

- Construtivismo: significados são construídos pelos seres humanos à medida que eles se envolvem com seu mundo e sua geração básica é sempre social; os pesquisadores tentam entender o contexto ou o ambiente dos participantes visitando e colhendo informações pessoalmente. Ideias centrais: entendimento, significados múltiplos do participante, geração de teoria.

- Reivindicatória/participativa: a investigação deve ser entrelaçada com política e caráter reformista, tratando de aspectos como poder, desigualdade, opressão e dominação. Ideias centrais: política, colaborativa e orientada para a mudança.

- Pragmatismo: não é comprometido com um único sistema filosófico, aplicando-se a métodos mistos, havendo liberdade para os pesquisadores escolherem métodos, técnicas e procedimentos. Ideias centrais: conseqüências das ações, centrado no problema, pluralista e orientada para prática no mundo real.

Segundo, partindo de suas suposições quanto à alegação de conhecimento, o pesquisador, de modo mais aplicado, define as Estratégias de Investigação que fornecerão 
uma direção específica para os procedimentos de sua pesquisa. Creswell (2007) apresenta as Estratégias de Investigação associadas às três técnicas de pesquisa:

- Quantitativa: projetos experimentais; projetos não-experimentais (levantamentos).

- Qualitativa: narrativas; fenomenologias; etnografias; teoria embasada na realidade; estudos de caso.

- Métodos Mistos: seqüiencial, simultânea; transformador.

O terceiro elemento principal que compõe uma pesquisa são os métodos de coleta e análise de dados. Sua escolha pelo pesquisador depende de seu objetivo: especificar o tipo de informação a ser coletada antes do estudo ou permitir que ela surja dos participantes do projeto. De acordo com Creswell (2007), os métodos existentes podem ser organizados conforme a técnica de pesquisa:

- Procedimentos Quantitativos: predeterminado; perguntas baseadas em instrumento; dados de desempenho, de atitude, observacionais e de censo; análise estatística.

- Procedimentos Qualitativos: métodos emergentes; questões abertas; dados de entrevista, de observação, de documentos e audiovisuais; análise de texto e imagem.

- Procedimentos Mistos: métodos predeterminados e emergentes; questões abertas e fechadas; formas múltiplas de dados contemplando todas as possibilidades; análise estatística e textual.

Nas próximas seções deste capítulo, os conceitos que envolvem a alegação de conhecimento, a estratégia de pesquisa e os métodos de coleta a análise de dados definidos pelo investigador serão apresentados detalhadamente.

\subsection{Alegação de Conhecimento: Abordagem Qualitativa}

O método qualitativo de pesquisa tem como sua abordagem mais influente a fenomenologia cujas principais disciplinas são a psicanálise, antropologia, psicologia e sociologia (TURATO, 2005). Por meio do estudo dos fenômenos, o pesquisador busca compreender a dinâmica do ser humano e porque as pessoas desenvolvem significados subjetivos para suas experiências de forma tão variada e múltipla (TURATO, 2005; CRESWELL, 2007). 
A presente pesquisa utilizou-se de métodos tipicamente qualitativos cujas principais características são:

a) Quanto ao papel e a importância do pesquisador: há uma forte interação no processo de pesquisa entre o investigador e o investigado, de maneira que os resultados são uma criação literal do processo de investigação. O pesquisador é o próprio "instrumento" de pesquisa, usando diretamente seus órgãos de sentido para apreender os objetos em estudo. Ele deve focalizar significados, procurar entender o que está acontecendo, olhar a totalidade de cada situação e desenvolver ideias a partir dos dados indutivamente. Deve interpretar os fenômenos sociais em termos dos sentidos que as pessoas lhe atribuem (MOREIRA; CALEFE, 2006; TURATO, 2005; EASTERBY-SMITH; THORPE; LOWE, 1999; POPE; MAYS, 2009).

b) Quanto ao ambiente de pesquisa: os dados/informações devem ser coletados diretamente no ambiente natural do sujeito, pois é lá onde ocorrerá a observação sem o controle das variáveis, diferentemente dos ambientes artificiais ou experimentais (MOREIRA; CALEFE, 2006; TURATO, 2005; POPE; MAYS, 2009).

c) Quanto ao uso de ferramentas e técnicas de coleta de dados: frequentemente são empregados múltiplos métodos qualitativos como observações, entrevistas individuais e coletivas, levantamento e leitura documental, diários, memórias analíticas e gravações. O propósito é estabelecer visões diferentes dos fenômenos, requerendo considerável habilidade e experiência dos pesquisadores (MOREIRA; CALEFE, 2006; EASTERBY-SMITH; THORPE; LOWE, 1999; POPE; MAYS, 2009).

d) Quanto à generalização: não sendo dos resultados obtidos, a generalização é possível a partir dos conceitos construídos ou conhecimentos originais produzidos (TURATO, 2005).

e) Quanto à amostra: é intencionada, em geral, com poucos sujeitos, pois a preocupação com o " $n$ ” é impertinente. Há busca proposital de indivíduos que vivenciam o problema em foco para serem investigados em profundidade ou ao longo do tempo, também denominado transversalmente (TURATO, 2005; EASTERBY-SMITH; THORPE; LOWE, 1999).

f) Quanto ao processo de pesquisa: durante toda sua execução é interativo com a análise, crítica, reiteração, reanálise etc., levando a uma construção articulada do caso (MOREIRA; CALEFE, 2006).

g) Quanto às hipóteses: o pesquisador inicia o trabalho de campo com um conjunto geral de problemas em mente e também com uma estrutura teórica, tendo suas hipóteses iniciais e posteriores revistas em um crescendo (MOREIRA; CALEFE, 2006; TURATO, 2005). 
O método qualitativo tem como principais forças sua capacidade para examinar processos de mudança ao longo do tempo, entender os significados das pessoas, ajustar-se a novas questões e ideias à medida que elas surgem, contribuir para a evolução de novas teorias e a validade dos dados coletados em profundidade (EASTERBY-SMITH; THORPE; LOWE, 1999; TURATO, 2005).

Todavia, ele apresenta importantes limitações de natureza epistemológica e metodológica:

- Questionamento a respeito do seu caráter científico, a sua sistemática, o seu rigor e capacidade analítica (MOREIRA; CALEFE, 2006; POPE; MAYS, 2009).

- Elevado grau de dependência do pesquisador, podendo comprometer sua objetividade (MOREIRA; CALEFE, 2006).

- É muito particular, localizado e conduzido em pequena escala, não permitindo fazer generalizações e replicações (MOREIRA; CALEFE, 2006; POPE; MAYS, 2009).

- A coleta de dados pode consumir muito tempo e recursos e a análise e interpretação potencialmente difíceis (EASTERBY-SMITH; THORPE; LOWE, 1999).

- Muita confiança em dados qualitativos, o que pode ser interpretado como uma historieta, impressão pessoal ou conjectura (MOREIRA; CALEFE, 2006; POPE; MAYS, 2009).

- Dificuldade para controlar o ritmo, progresso e pontos finais da pesquisa (EASTERBYSMITH; THORPE; LOWE, 1999).

\subsection{A Estratégia de Pesquisa: o Estudo de Caso}

O Estudo de Caso tem suas raízes nas ciências sociais, particularmente nos estudos etnográficos e antropológicos (VOSS; TSIKRIKTSIS; FROHLICH, 2002); por definição, trata-se de uma estratégia de pesquisa para investigar empiricamente um fenômeno contemporâneo dentro de seu contexto da vida real - em cenários singulares, únicos - sem limites claramente definidos entre fenômeno e contexto, e sem o controle do pesquisador (YIN, 2005; STAKE 1995 EISENHARDT, 1989).

No estudo de caso, o investigador explora, examina e procura entender variáveischaves em profundidade na forma de uma análise intensiva com o propósito de prover detalhados elementos sobre um fenômeno de interesse (APPLETON, 2002) que pode ser: um 
programa, um fato, uma atividade, um processo ou uma ou mais pessoas (CRESWELL, 2007).

Do ponto de vista de suas aplicações, Yin (2005) entende que o estudo de caso tem como principais finalidades:

- Explicar os supostos vínculos causais em intervenções da vida real que são complexas demais para estratégias experimentais ou levantamentos;

- Descrever uma intervenção e o contexto na vida real em que ele ocorre;

- Ilustrar certos tópicos dentro de uma avaliação de modo descritivo;

- Explorar as situações nas quais a intervenção que está sendo avaliada não apresenta um conjunto simples e claro de resultados; e

- Possibilitar "meta-avaliação", estudo de estudos de avaliações.

Stake (2003), com sua orientação construtivista (APPLETON, 2002), afirma que o estudo de caso é uma forma de pesquisa definida pelo interesse em casos individuais, não pelos métodos de investigação utilizados. Ele pode ser simples ou complexo, seu tempo de investigação curto ou longo, porém, enquanto estiver concentrado na sua investigação, o pesquisador deverá engajar-se completamente no caso escolhido (STAKE, 1995, 2003).

A investigação no estudo de caso enfrenta uma situação tecnicamente única onde haverá muito mais variáveis de interesse do que pontos de dados (YIN, 2005). Destarte, podem ser usadas na coleta múltiplas fontes de dados (CRESWELL, 2007; YIN, 2005; STAKE, 1995) para formar a mais completa figura a respeito do fenômeno investigado (APPLETON, 2002), o que permite incluir evidências quantitativas (números), qualitativas (palavras) ou ambas: arquivos, entrevistas e questionários (EISENHARDT, 1989; YIN, 2005).

Yin (2005) e Stake (1995), a partir de suas orientações paradigmática positivista e construtivista, respectivamente, têm visões próprias, profundamente divergentes sob certos aspectos, quando tratam de questões como tipologia, uso da teoria e generalização no estudo de caso (APPLETON, 2002).

Para Stake (1995, 2003), os estudos de caso podem ser tipificados em três categorias que enfatizam variações no tocante a orientação metodológica, portanto, utilizam-se métodos de pesquisa diferentes conforme os interesses: 
Estudo de caso Intrínseco: em algumas circunstâncias, o caso é dado ou imposto ao investigador que é obrigado a estudá-lo; por exemplo, uma professora que decide investigar o caso de um aluno com dificuldades de aprendizado. Logo, desde o começo até o fim, o pesquisador buscará um melhor entendimento do caso em particular não porque o estudando poderá aprender sobre outros casos, construir uma teoria, entender um constructo abstrato ou fenômeno genérico, mas porque precisa aprender sobre este caso em particular.

Estudo de caso Instrumental: assim denominado se um caso em particular é examinado principalmente para permitir o aprofundamento em uma questão ou produzir generalização. $\mathrm{O}$ caso em si é secundário e desempenha papel de apoio porque visa facilitar o entendimento sobre outro interesse. $\mathrm{O}$ aprofundamento na investigação não é a atividade fim e sim o meio para auxiliar o pesquisador a procurar um interesse externo. O caso pode ser visto como típico de outros casos ou não, pois sua escolha é feita para avançar no entendimento de outro interesse. Como o pesquisador tem vários interesses simultâneos, particular e geral, não há uma clara separação entre o estudo de caso intrínseco e o instrumental; uma região de interesses combinados os separa.

Estudo de caso coletivo: é o estudo instrumental estendido para vários casos quando o pesquisador os reúne com o propósito de investigar um fenômeno, uma população ou condição geral. O pesquisador os escolhe, podendo ou não ser conhecidos antecipadamente, para manifestar alguma característica em comum. Eles podem ser semelhantes ou não porque se acredita que os compreendendo consegue-se um melhor entendimento de uma coleção de casos mais ampla onde redundância e variedade são importantes.

A tipologia de Yin (2005) para o desenho de estudo de caso é o resultado da interrelação entre projetos holísticos e incorporados (o envolvimento de mais de uma unidade de análise dentro de um estudo de caso) e casos únicos e casos múltiplos, conforme apresentado na Figura 4.1: 


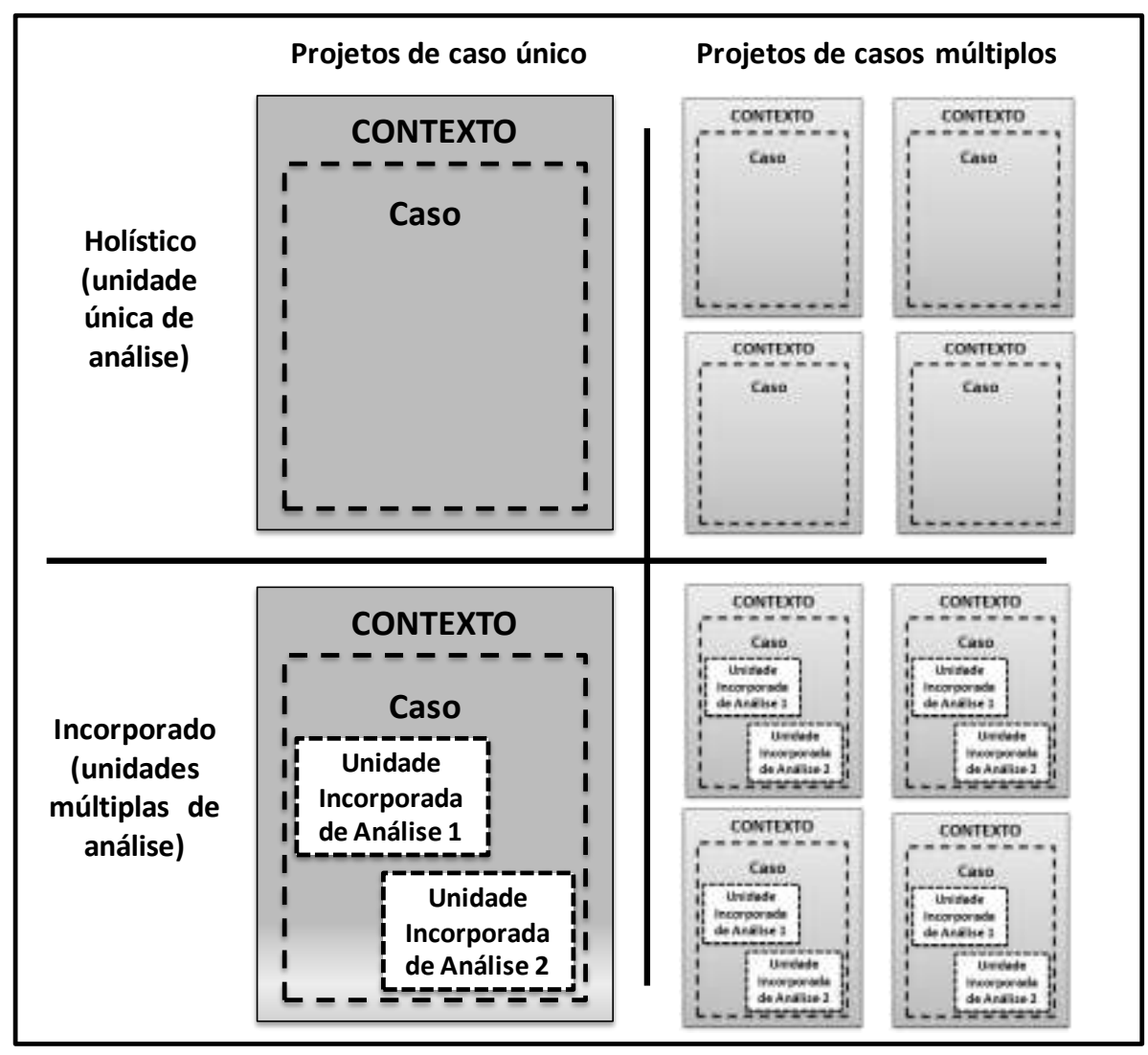

Figura 4.1: Tipos de estudos de caso Fonte: YIN (2005, p. 61)

O estudo de Casos Múltiplos (YIN, 2005) deve seguir uma lógica de replicação e não de amostragem e funcionar de maneira semelhante aos experimentos múltiplos. Assim, estudos de caso, em geral, não devem ser utilizados para avaliar a incidência de fenômenos (prevalência ou freqüência). Cada caso em particular consiste em um estudo "completo" no qual se procuram evidências convergentes com relação aos fatos e às conclusões para o caso.

Sendo assim, cabe ao pesquisador selecionar cuidadosamente cada caso de forma a prever resultados semelhantes (replicação literal) ou produzir resultados contrastantes apenas por razões previsíveis (replicação teórica). O número de replicações teóricas diz respeito à compreensão do pesquisador quanto à complexidade do domínio de validade externa. $\mathrm{Na}$ hipótese de desconhecer os efeitos das condições externas sobre os resultados, o pesquisador pode recorrer a um número maior de casos (YIN, 2005).

Comparativamente ao estudo de caso único, a exigência de tempo e recursos utilizados nos estudos de casos múltiplos são maiores, porém, podem-se alcançar os seguintes benefícios (YIN, 2005):

- Possibilidade de replicação direta; 
- Provável variedade de contextos entre os casos;

- Conclusões comuns a partir dos casos que reforçam a capacidade externa de generalização das descobertas; e

- Ter mais de um caso mitiga a crítica com unicidade ou condições "arte factuais" que circundam o caso (por exemplo, acesso especial a um informante-chave).

Com relação à importância do desenvolvimento de uma estrutura teórica para o estudo de caso, independente de ser explanatório, descritivo ou exploratório, Yin (2005, p. 54) afirma que ela "[...] representa uma ajuda imensa na definição do projeto de pesquisa e na coleta de dados adequados, como também se torna o veículo principal para generalização dos resultados do estudo de caso."

Voss, Tsikriktsis e Frohlich (2002) compartilham da mesma opinião porquanto a moldura conceitual suporta a pesquisa com os principais pontos a serem estudados e força o pesquisador a pensar cuidadosamente e seletivamente sobre os constructos e as variáveis a serem incluídas na investigação.

Stake (2003), novamente tem uma visão distinta de Yin, evidentemente suportada pela sua filosofia construtivista. A escolha da amostra é proposital porque o pesquisador examina vários interesses no fenômeno, selecionando um caso de alguma tipicidade, esperando aprender o máximo a partir dele. Portanto, sem o enfoque na replicação lógica de Yin (2005).

Seguindo com o pensamento de Stake (1995, 2003), a escolha proposital pode significar escolher o caso mais acessível, fácil de investigar, com os informantes prospectivos dispostos a comentar, participar. O importante é maximizar o que queremos aprender; um caso em que o pesquisador possa investir o maior tempo possível na sua investigação; afinal, a ênfase está na interpretação e cada caso é único.

Para Stake (1995), estudos de caso são valiosos para refinamento da teoria e sugerem complexidades para futuras investigações, assim como uma ajuda para estabelecer limites para generalizações. E conclui: "O verdadeiro negócio do estudo de caso é a particularização, não generalização.” (STAKE, 1995, p.8).

As principais críticas ao uso do estudo de caso como estratégia de pesquisa são: sua limitada capacidade de aplicação dos resultados para outras empresas (HAUGH; McKEE, 2004); seu caráter investigativo subjetivo; o alto risco ético inerente; as contribuições para a ciência disciplinada são lentas e tendenciosas com elevados custos de tempo e dinheiro 
(STAKE, 1995); resultam em inúmeros documentos ilegíveis; e oferecem pouca base para fazer uma generalização científica (YIN, 2005).

Por fim, é importante destacar que o método do estudo de caso vem ganhando, assim como outras estratégias de abordagem qualitativa, aceitação dentro da comunidade de pesquisa sobre a pequena empresa (PERREN; RAM, 2004), objeto de estudo da presente pesquisa.

\subsection{Características Pessoais e o Papel do Pesquisador}

Segundo Stake (1995), todos os pesquisadores qualitativos têm um grande privilégio e também uma obrigação: o privilégio de prestar atenção naquilo que entendem ser o mais relevante a ser observado e a obrigação de tirar conclusões de suas escolhas que tenham significado importante para seus colegas e clientes.

Diante de tamanha responsabilidade, uma das principais qualificações para o investigador é a experiência que conduz para o entendimento, reconhecimento de boas fontes de dados e, consciente ou inconscientemente, testar a veracidade daquilo que vê e a robustez de suas interpretações. Não raramente, observando o comum pelo tempo que for necessário para compreender o que o comum significa. Isso com sensibilidade e certa dose de ceticismo, postura isenta que não chame a atenção para si e não criando situações para testar suas hipóteses (STAKE, 1995).

Yin $(2005$, p. 82) destaca que as "[...] as exigências que um estudo de caso faz em relação ao intelecto, ao ego e às emoções de uma pessoa são muito maiores do que aqueles de qualquer outra estratégia de pesquisa.”. Isso porque os procedimentos do estudo de caso não seguem uma rotina, exigindo um pesquisador bem treinado e experiente para conduzir o trabalho investigativo em todas suas etapas.

Seguindo na linha de sua perspectiva positivista, Yin (2005) oferece uma lista básica de habilidades comumente exigidas do pesquisador, ainda que não natas, mas que podem ser corrigidas e desenvolvidas:

- Ser capaz de fazer boas perguntas e interpretar as respostas;

- Ser um bom ouvinte e não ser enganado pelas suas ideologias e preconceitos;

- Ser adaptável e flexível para tirar vantagem de mudanças que signifiquem oportunidades inesperadas e não encará-las como ameaças; 
- Ter uma noção clara das questões que estão sendo estudadas com foco nos eventos e nas informações relevantes que devem ser buscadas a proporções administráveis; e

- Deve ser imparcial em relação a noções preconcebidas; ser sensível e atento a provas contraditórias.

Poder-se-ia acrescentar, com base na visão de Creswell (2007), a capacidade que o pesquisador qualitativo deve ter na forma literária de redação e o conhecimento de programas de análise de texto por computador. Pois, dominando-as, ele pode ser inovador e trabalhar mais nos limites de suas estruturas projetadas bem como no uso de uma redação mais criativa com estilo literário mais ao seu gosto.

Easterby-Smith, Thorpe e Lowe (1999), no seu trabalho focado na pesquisa gerencial em administração, reforçam em parte o entendimento de Stake (1995) sobre a influência direta que a visão de mundo do investigador tem nas suas escolhas e prioridades. Em especial, a relevância da experiência passada do pesquisador determinando o interesse e sua capacidade para identificar fenômenos e perguntas importantes.

Os autores também contribuem com outros elementos mais próximos das características individuais do pesquisador qualitativo, alguns alinhados com a descrição das habilidades listadas por Yin (2005). Por exemplo (EASTERBY-SMITH; THORPE; LOWE, 1999):

- A formação pessoal e a classe social do pesquisador afetam seu trabalho de campo influenciando, entre outros aspectos, a acessibilidade aos entrevistados e predeterminação de respostas;

- Ele precisa ser sensível a eventos, flexível para lidar com mudanças repentinas, hábil ouvinte e observador criterioso de gestos, roupas e linguagem utilizado pelos entrevistados e se abster de projetar opiniões ou sentimentos; e

- Ter habilidade para conduzir entrevistas em profundidade, fazer anotações de campo, codificar e interpretar transcrições.

Stake (1995) talvez consiga abordar de melhor forma a questão do pesquisador no estudo de caso ao colocar sua participação e importância utilizando-se da analogia dos papéis a serem desempenhados pelo investigador durante todo seu trabalho - professor, defensor de ponto de vista, avaliador, biógrafo, interprete entre outros - e que faz escolhas em como interpretá-los ao avaliar continuamente: 
- Quanto participar pessoalmente nas atividades do caso;

- Quanto se posicionar como especialista, quanto de compreensão revelar;

- Ser um observador neutro ou avaliativo, analista crítico;

- Quanto atender as necessidades de leitores ansiosos;

- Qual a medida que irá interpretar o caso;

- Quanto defender uma posição;

- Contar ou não o caso como uma história.

\subsection{Técnicas de Coleta de Dados}

Os procedimentos para coletar os dados devem ser administrados para garantir que cada fonte seja adequadamente utilizada, logo, nem todas elas serão importantes para todos os estudos de caso (YIN, 2005). Nessa seção, será oferecida uma visão geral dos principais tipos de instrumentos de coleta de dados qualitativos, segundo a bibliografia pesquisada. Para aqueles usados na etapa de campo desse trabalho (observação e análise documental), serão oferecidas informações técnicas bem mais detalhadas.

Ainda que seja recomendável para o pesquisador o uso de várias fontes de evidência (APPLETON, 2002; EISENHARDT, 1989; STAKE, 1995; YIN, 2005;) é impraticável - pelo volume e capacidade no tratamento de dados - o uso de todos os instrumentos simultaneamente em uma única investigação qualitativa, em especial, o estudo de caso.

Porém, é importante que o pesquisador esteja ciente das alternativas disponíveis, bem como conheça as vantagens e limitações de cada uma, propósito da visão geral exposta no Quadro 4.1: 


\begin{tabular}{|c|c|c|c|}
\hline $\begin{array}{l}\text { Tipos de coleta de } \\
\text { dados ou fontes de } \\
\text { evidência }\end{array}$ & $\begin{array}{l}\text { Opções dentro dos } \\
\text { tipos }\end{array}$ & Vantagens & Limitações \\
\hline Observações & $\begin{array}{l}\text { - Participante } \\
\text { completo: } \\
\text { pesquisador oculta o } \\
\text { papel } \\
\text { - Observador como } \\
\text { participante: papel } \\
\text { do pesquisador é } \\
\text { conhecido } \\
\text { - Observador } \\
\text { completo: } \\
\text { pesquisador observa } \\
\text { sem participar }\end{array}$ & $\begin{array}{l}\text { - Pesquisador tem uma } \\
\text { experiência real com os } \\
\text { participantes } \\
\text { - Pesquisador pode registrar } \\
\text { informações contextuais } \\
\text { - Aspectos não usuais } \\
\text { podem ser notados durante } \\
\text { a observação }\end{array}$ & $\begin{array}{l}\text { - Consomem muito } \\
\text { tempo e custo } \\
\text { - Efeito "Hawthorne" da } \\
\text { presença do } \\
\text { pesquisador } \\
\text { - Participante pode ser } \\
\text { visto como intruso } \\
\text { - Podem ser observadas } \\
\text { informações privadas } \\
\text { que o pesquisador não } \\
\text { pode relatar } \\
\text { - O pesquisador pode } \\
\text { não ter boas aptidões } \\
\text { para observação }\end{array}$ \\
\hline Entrevistas & $\begin{array}{l}\text { - Pessoal/face a face } \\
\text { - Telefone } \\
\text { - Grupo }\end{array}$ & $\begin{array}{l}\text { - Quando os participantes } \\
\text { não podem ser observados } \\
\text { diretamente } \\
\text { - Enfocam diretamente o } \\
\text { tópico em estudo } \\
\text { - Pesquisador controla a } \\
\text { linha de questionamento }\end{array}$ & $\begin{array}{l}\text { - Informações com viés } \\
\text { do respondente ou } \\
\text { indução do pesquisador } \\
\text { - As pessoas não são } \\
\text { igualmente } \\
\text { comunicativas } \\
\text { - Não capta } \\
\text { completamente o } \\
\text { contexto }\end{array}$ \\
\hline Documentos & $\begin{array}{l}\text { - Públicos: atas de } \\
\text { reuniões, imprensa } \\
\text { em geral, sites } \\
\text { - Privados: registros, } \\
\text { diários, } \\
\text { correspondências }\end{array}$ & $\begin{array}{l}\text { - Obter a linguagem e } \\
\text { palavras dos participantes } \\
\text { - Acessibilidade conforme } \\
\text { conveniência das partes } \\
\text { - Estável - pode ser } \\
\text { revisada conforme a } \\
\text { necessidade } \\
\text { - Exatidão de nomes, } \\
\text { referências, eventos }\end{array}$ & $\begin{array}{l}\text { - Indisponibilidade de } \\
\text { acesso por sigilo } \\
\text { - Materiais podem estar } \\
\text { incompletos, não } \\
\text { autênticos ou } \\
\text { imprecisos } \\
\text { - Seletividade } \\
\text { tendenciosa }\end{array}$ \\
\hline $\begin{array}{l}\text { Materiais } \\
\text { audiovisuais }\end{array}$ & $\begin{array}{l}\text { - Fotografias } \\
\text { - Filmes e Vídeos } \\
\text { - Objetos de arte } \\
\text { - Softwares }\end{array}$ & $\begin{array}{l}- \text { Criativo } \\
\text { - Compartilhamento da } \\
\text { realidade } \\
\text { - Percepção aspectos } \\
\text { culturais }\end{array}$ & $\begin{array}{l}\text { - Difícil de interpretar } \\
\text { - Inacessível } \\
\text { - Seletividade } \\
\text { - Disponibilidade }\end{array}$ \\
\hline
\end{tabular}

Três tipos de método de coleta de dados são geralmente usados nas pesquisas que tratam do trabalho do administrador: observação direta, entrevista e os diários. As duas primeiras são particularmente importantes para os estudos de campo, que examinam as práticas de trabalho e os acontecimentos in loco. Por exemplo, a observação permite conhecer situações que não ocorreriam fora do contexto em que realmente se passam e as entrevistas permitem ao investigador saber o que as pessoas pensam a respeito de seu trabalho e questões que acreditam ser importantes (NOORDEGRAAF; STEWART, 2000; ANDERSON, FLORÉN, 2009; BARLEY; KUNDA, 2001).

O primeiro tipo de instrumento de coleta dados qualitativos a ser detalhado nessa seção será a técnica de Observação, especialmente adequada para estudos exploratórios, permitindo: o conhecimento fundamental sobre o trabalho do administrador, pela proximidade do pesquisador em relação ao fenômeno; como as organizações funcionam; os papéis desempenhados pelas pessoas; e a interação entre elas (ANDERSON; FLORÉN, 2009; POPE; MAYS, 2009). 
Ao aplicar a técnica de Observação, o pesquisador toma notas no campo, registrando de maneira não-estruturada ou estruturada (usando referências preparadas anteriormente), o comportamento e as atividades das pessoas, durante certos períodos de tempo. A coleta de evidências deve ocorrer no ambiente natural (reuniões empresariais, trabalhos na fábrica, instalações etc.) e o investigador deverá manter um bom registro dos eventos para oferecer uma descrição incontestável para análises comparativas (casos cruzados) e relatório final (CRESWELL, 2007; YIN, 2005; STAKE, 1995; ANDERSSON; FLORÉN, 2009).

Segundo Pope e Mays (2009), para atingir um elevado patamar de qualidade nos estudos observacionais, é importante detalhar, da melhor forma possível, como a pesquisa foi conduzida, informando:

- O tempo de campo;

- A proximidade do pesquisador com o ato ou o comportamento discutido;

- A tipicidade dos eventos; e

- As tentativas de verificar as observações feitas.

O propósito é conseguir a congruência, ou seja, o quanto a pesquisa fornece de instruções ou regras que permitam a outro pesquisador ingressar no mesmo ambiente (POPE; MAYS, 2009).

O segundo instrumento de coleta de dados qualitativos é a Entrevista, pois muito do que não se consegue observar será captado por outras pessoas e a maneira de acessar esse conhecimento é por meio de entrevistas (STAKE, 1995).

Segundo Britten (2009), existem três tipos principais de entrevista: estruturada (geralmente com questionário); semi-estruturada (perguntas abertas); em profundidade (um ou dois assuntos cobertos detalhadamente, perguntas baseadas no que a o entrevistado diz).

Easterby-Smith, Thorpe e Lowe (1999) corroboram com a visão, afirmando que as entrevistas podem ser altamente estruturadas ou uma conversação livre. Assim, o principal objetivo da entrevista é compreender os significados que os entrevistados atribuem a questões e situações em contextos que não são antecipadamente estruturados pelas suposições do pesquisador. E acrescentam que: as entrevistas são particularmente úteis quando a lógica de uma situação não está clara; o assunto é altamente confidencial; e o entrevistado não se sente à vontade para oferecer certos tipos de informação para qualquer um. 
Uma boa entrevista requer planejamento pois raramente as mesmas perguntas são colocadas para todos os entrevistados. Pelo contrário, espera-se que cada uma seja uma experiência única, com mais do que simples "sim" e "não" nas respostas; mas, a descrição de um episódio, uma explanação (STAKE, 1995). Portanto, conforme Britten (2009, p. 25) "O pesquisador precisa permanecer aberto às possibilidades de os conceitos e as variáveis emergentes serem muito diferentes daqueles previstos no início.”

O planejamento também requer preparar a entrevista com cuidados importantes para o seu sucesso (STAKE, 1995; BRITTEN, 2009; EASTERBY-SMITH; THORPE; LOWE, 1999; YIN, 2005):

a) Antes de realizá-la: fazer um treinamento mental, simulando as questões e suas possíveis respostas; agendar a entrevista conforme a conveniência de dia, hora e local para o respondente; explicar para o entrevistado os objetivos e a relevância da pesquisa, provável duração e caráter anônimo e confidencial no tratamento das informações.

b) Durante a entrevista: manter o controle de sua execução (checagem de informações); buscar a interação social com o entrevistado e conseguir sua confiança; saber o que quer descobrir, seguindo sua própria linha de investigação; fazer perguntas certas, não tendenciosas ou embaraçosas, que sejam "amigáveis" e "não ameaçadoras" para obter a informação desejada; ter atenção para possíveis vieses de ambas as partes; oferecer devoluções verbais e não-verbais; evitar interrupções e distrações; não pular de um assunto para outro; evitar agir ensinando, aconselhando, colocando as próprias perspectivas durante a entrevista; manter um elevado padrão ético.

c) Depois da entrevista: organizar e tratar os dados coletados - preferencialmente logo após a entrevista para que não se perca nenhum detalhe importante das evidências.

O terceiro e último instrumento de coleta de dados qualitativos a ser detalhado é a análise de Documentos. Praticamente, todo estudo apresenta alguma necessidade de examinar jornais, relatórios anuais, correspondências, minutas de reunião entre outras evidências, podendo ser analisados por frequiência ou contingência. Todavia, requer os mesmos cuidados com planejamento das técnicas de observação e entrevista pois muitas vezes o volume de documentos e o tempo necessário para processá-los é muito maior do que o estimado (STAKE, 1995). 
O uso de Documentos em pesquisas de dados qualitativos tem importância especial para corroborar e valorizar evidências originárias de outras fontes, sendo úteis para (YIN, 2005; STAKE, 1995; BARLEY; KUNDA, 2001):

- Verificação de grafia correta, cargos e nomes citados durante as entrevistas;

- Fazer inferências a partir de documentos, por exemplo, entender a rede de contatos pessoais e os meios e canais usados na comunicação interna e externa;

- Substituição de registros de atividades que o pesquisador não conseguiu observar diretamente, por exemplo, o trabalho no computador. Neste caso, pela leitura de documentos eletrônicos e e-mails é possível rastrear as informações (tipo, origem, destino).

Yin (2005) sugere a adoção de três princípios para coleta de dados qualitativos que ajudam o pesquisador a fazer frente ao problema de estabelecer a validade do constructo e a confiabilidade nos estudo de caso:

a) Utilizar várias fontes de dados: permite ao pesquisador dedicar-se a uma ampla diversidade de questões históricas, comportamentais e de atitude; desenvolvendo linhas convergentes de investigação (triangulação de dados). Dessa forma, consegue-se maior credibilidade e acuracidade às descobertas e conclusões do estudo de caso. Entretanto, importante ressaltar que a adoção de várias fontes é relativamente mais cara e exige um leque de habilidades e conhecimentos mais amplo do pesquisador.

b) Criar um banco de dados para o estudo de caso: formal e apresentável que permita a outros pesquisadores revisar as evidências diretamente, aumentando a confiabilidade do estudo. Os componentes do banco de dados são as notas e documentos para o estudo de caso; tabelas; narrativas.

c) Manter o encadeamento das evidências: o objetivo é permitir a qualquer observador externo siga a origem de qualquer evidência, partindo das questões originais da pesquisa até chegar às conclusões finais do estudo de caso.

A presente pesquisa, seguindo a tradição de estudos anteriores que se dedicaram a investigar o trabalho do administrador de forma indutiva e descritiva (ANDERSSON; FLORÉN, 2009; ARMAN et al., 2009; FLORÉN, 2006; FLORÉN; TELL, 2006, 2009; 
MINTZBERG, 1973; O’GORMAN; BOURKE; MURRAY, 2005; TENGBLAD, 2006; TONELLI, 2005; WAHLGRÉN, STEWART, 2003) foi conduzida:

- Por um único pesquisador;

- Utilizando-se de múltiplas fontes como a observação não-participante estruturada e a análise documental; e

- Conforme protocolo elaborado previamente (APÊNDICE C).

A intenção foi permitir ao pesquisador maior liberdade para coleta de diferentes tipos de dados utilizáveis para análises comparativas e incluir evidências quantitativas e qualitativas para formar a mais completa figura a respeito do fenômeno investigado (MINTZBERG, 1973; APPLETON, 2002; CRESWELL, 2007; EISENHARDT, 1989; STAKE, 1995; YIN, 2005).

Três tipos de registros dos dados foram feitos na etapa de campo: cronológico (anotar cada atividade e sua duração), documentos recebidos e enviados (e-mails, cartas etc.) e registro dos contatos pessoais do dirigente durante sua rotina diária de trabalho (meio, finalidade, participantes, local e iniciativa).

Além do uso dos instrumentos para o registro estruturado dos eventos (formulários com categorias de atividades pré-determinadas), também foram usadas notas pessoais para registro de comentários, observações e complementos pelo investigador (ARMAN et al., 2009).

A presença do pesquisador durante a observação estruturada poderia causar algum efeito no trabalho regular do dirigente, seus contatos internos e externos, e no resultado dos dados coletados, conhecido como efeito Hawthorne (MINTZBERG, 1970).

Para minimizar este risco potencial, algumas medidas preventivas foram tomadas pelo pesquisador (MINTZBERG, 1970; TONELLI, 2005; ARMAN et al., 2009), a saber:

- Orientar o dirigente como se comportar diante de situações inesperadas (assuntos confidenciais, interrupções etc.);

- Os funcionários diretos do dirigente teriam informações a respeito do trabalho em desenvolvimento e como deveriam reagir a ele;

- O agendamento das datas de coleta não deveria acontecer em períodos reconhecidamente atípicos para a empresa e seu dirigente (a intenção é que ocorresse em uma semana “típica'); e 
- O pesquisador não tomaria a iniciativa em conversas, exceto aquelas necessárias para algum esclarecimento ou com a finalidade de operacionalizar a investigação.

\subsection{Procedimentos para Análise de Dados}

De acordo com Pope, Ziebland e Mays (2009), nas pesquisas com abordagem qualitativa, o processo analítico começa durante a coleta de dados pois esses já são analisados e inseridos ou formatam a coleta de dados em andamento. Dessa forma, permite que o pesquisador confira e interprete os dados que está continuamente coletando e desenvolva hipóteses para investigações subseqüentes.

Yin (2005) afirma que a análise de dados consiste no exame, categorização, classificação em tabelas, teste ou recombinação de evidências quantitativas e qualitativas do estudo. E complementa "Analisar as evidências de um estudo de caso é uma atividade particularmente difícil [...]” (YIN, 2005, p. 137). O que corrobora com a visão de Eisenhardt (1989, p. 539) de que a análise de dados é o coração do desenvolvimento de teoria "[...] mas é a parte mais difícil e a menos codificada do processo.".

Talvez por essa confessa dificuldade, Eisenhardt (1989), no seu modelo de construção de teoria a partir de estudo de caso, propõe duas formas de análise de dados na investigação qualitativa:

a) Análise dos dados do caso internamente: é a organização dos dados por categorias com auxilio de tabelas com a finalidade de que se tornem tão familiar com cada caso como se fosse uma entidade isolada. O processo permite que emirja de cada caso um padrão único antes da generalização entre outros casos. Além do mais, dá ao investigador uma rica familiarização com cada caso, acelerando a comparação cruzada entre casos.

b) Análise de dados de casos cruzados: nesta forma de análise, uma alternativa é a seleção de categorias ou dimensões e a busca por similaridades ou diferenças entre os casos. As dimensões podem ser sugeridas pela teoria ou pelo problema de pesquisa, ou simplesmente o pesquisador escolhe algumas dimensões. Outra possibilidade é o pesquisador selecionar pares de casos e listar semelhanças e diferenças entre cada par, podendo estender para grupos de análise maior (três ou quatro casos) de comparação. 
$\mathrm{Na}$ presente pesquisa foi estudado um único fenômeno (a natureza do trabalho do administrador), considerando sua dinâmica, contexto e significado subjetivo (TURATO, 2005).

Portanto, adotou-se a abordagem qualitativa caracterizando a pesquisa nos seguintes aspectos:

- Pesquisador com papel ativo e forte interação no processo de pesquisa;

- Os dados coletados no ambiente natural de pesquisa;

- Múltiplas ferramentas de coleta de dados;

- Amostra intencionada com poucos sujeitos; e

- Construção articulada do caso: coleta e análise concomitante.

Como estratégia de investigação se utilizou o estudo de caso coletivo (STAKE, 1995) ou casos múltiplos (YIN, 2005), onde um fenômeno contemporâneo foi pesquisado dentro de seu contexto da vida real sem limites claramente definidos entre fenômeno e contexto, e sem o controle do pesquisador (EISENHARDT, 1989; STAKE, 1995; YIN, 2005).

A técnica da observação estruturada e o modelo dos papéis de Mintzberg (1973, 2010) serviram de estrutura conceitual teórica para o desenvolvimento dos instrumentos de coleta de dados e respectiva análise dos resultados.

Dois diferentes tipos de dados quantitativos foram coletados no campo: frequiência (número de atividades desempenhadas pelos dirigentes) e duração (período de tempo das atividades desempenhadas). Os dados coletados por meio da observação estruturada foram analisados utilizando estatística descritiva.

O processo de análise de dados coletados foi feito internamente no caso e entre casos cruzados utilizando quatro dimensões e categorias pré-determinadas, em linha com outros estudos (TENGBLAD, 2006; FLORÉN; TELL, 2006; ARMAN et al., 2009) baseados no trabalho de Mintzberg (1971, 1973), conforme Quadro 4.2: 


\begin{tabular}{|c|c|c|c|c|}
\hline \multicolumn{5}{|c|}{ Dimensões } \\
\hline \multirow{9}{*}{ 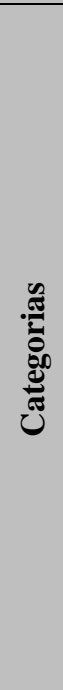 } & 1. Tipo de atividade & 2. Lugar & 3. Participantes & $\begin{array}{l}\text { 4. Iniciativa do } \\
\text { contato }\end{array}$ \\
\hline & 1.1 Reunião agendada & 2.1 Escritório dirigente & 3.1 Subordinados & 4.1 Própria \\
\hline & 1.2 Reunião não agendada & $\begin{array}{l}\text { 2.2 Escritório } \\
\text { funcionário }\end{array}$ & 3.2 Cliente & 4.2 Planejada \\
\hline & 1.3 Visitas internas empresa & 2.3 Área operacional & 3.3 Outros & 4.3 Outras \\
\hline & 1.4 Mesa de trabalho & 2.4 Outro lugar empresa & & \\
\hline & 1.5 Telefonemas & 2.5 Fora da empresa & & \\
\hline & 1.6 Intervalos & & & \\
\hline & 1.7 Assuntos pessoais & & & \\
\hline & $\begin{array}{l}1.8 \text { Interação com } \\
\text { pesquisador }\end{array}$ & & & \\
\hline
\end{tabular}

Quadro 4.2: Dimensões e categorias das atividades do dirigente

Fonte: Elaborado de Tengblad (2006), Florén e Tell (2006) e Arman et al. (2009)

O modelo das Demandas, Restrições e Escolhas de Stewart (1979, 1982) foi utilizado como referencial teórico para entender porque dirigentes da pequena empresa em trabalhos similares executam-no de forma diferente.

A análise dos resultados permitiu a comparação com outros estudos que utilizaram as mesmas estruturas teóricas de Mintzberg (1973). O teste estatístico dos dados não foi executado pela característica proposital da amostra e seu reduzido tamanho.

\subsection{Delimitações do Estudo}

A presente pesquisa tem por tema o trabalho do administrador e o objeto de estudo é a pequena empresa. O objetivo é avaliar, por meio do estudo de casos múltiplos, as coerências e divergências entre a explicação da natureza do trabalho do dirigente da pequena empresa e as teorizações existentes na literatura administrativa.

Dois dirigentes de pequenas empresas foram acompanhados e observados durante sua rotina diária, no seu local de trabalho (ambiente natural), por uma semana cada um, mesmo tempo dos estudos de Mintzberg (1971), Tengblad (2006) e Florén e Tell (2006).

O tamanho da amostra (dois casos) permitiu o enriquecimento dos dados coletados ainda dentro do limite de tempo disponível para a pesquisa, cuja finalidade foi coletar informações sobre as características (o que faz; como aloca seu tempo; com quem interage e 
se comunica; elementos informais do seu trabalho) e o conteúdo (papéis que desempenha) do trabalho do dirigente da pequena empresa.

O método qualitativo tem como uma de suas principais forças sua capacidade de ajustar-se a novas questões e ideias à medida que surgem (EASTERBY-SMITH; THORPE; LOWE, 1999; TURATO, 2005). Assim como, o estudo de caso piloto auxilia o pesquisador a aprimorar planos para coleta de dados em relação ao conteúdo e procedimentos (YIN, 2005). Portanto, o primeiro caso a ser estudado teve os dados colhidos e analisados por completo, com especial atenção para as categorizações, servindo de aprendizado.

As empresas foram selecionadas usando escolha amostral proposital, mais acessível, fácil de investigar, com informantes dispostos a comentar e participar, pois o interesse do pesquisador está no fenômeno, esperando aprender o máximo dele (STAKE, 2003; O’GORMAN et al., 2005). As empresas escolhidas atenderam os seguintes critérios:

- Sediadas no Estado de SP, podendo ou não ter negócios ou filiais em outros estados ou países;

- Não serem franqueadas ou filiais de alguma grande empresa;

- O gênero, grau de educação formal e experiência profissional do dirigente da empresa não seriam objeto de restrição na escolha com o objetivo de incrementar a variedade na descrição qualitativa (ARMAN et al., 2009);

- Terem na sua direção um sócio-proprietário que se dedique exclusivamente a gestão do seu negócio;

- Pertencentes a qualquer um dos setores de atividade: comércio, indústria ou serviços;

- Classificadas como pequenas, entre 20 e 99 funcionários para indústria e 10 a 49 para comércio e serviços, conforme critérios quantitativos do SEBRAE (2006);

- Terem pelo menos cinco anos de existência, o que exclui empresas iniciantes;

- Poderiam fazer parte de arranjos produtivos locais ou incubadoras de empresas; e

- Preferencialmente, que fizessem parte da rede de contatos profissionais do pesquisador para facilitar o acesso aos seus dirigentes e informações e conquistar seu interesse na participação. O que, consequentemente, contribuiria para a validade do estudo (FLORÉN; TELL, 2006). 


\subsection{Considerações Éticas}

A importância das questões éticas nos projetos de pesquisa, em especial nos estudos qualitativos, pode ser avaliada pela recorrência com que o assunto é tratado por diferentes autores com relevantes trabalhos publicados: Stake (1995, 2003), Yin (2005), Goodwin (2009), Creswell (2007) e Easterby-Smith, Thorpe e Lowe (1999).

Sendo o pesquisador o próprio instrumento de pesquisa e interagindo diretamente no ambiente natural (TURATO, 2005; MOREIRA; CALEFE, 2006), ele é um convidado em espaços privados do mundo, suas maneiras devem ser boas e seu código de ética rigoroso, seguindo regras de proteção dos sujeitos e cientes dos riscos que correm, inerentes da sua participação (STAKE, 2003).

Portanto, é importante que o pesquisador exerça sua devida responsabilidade ética para não prejudicar os interesses das demais partes envolvidas (EASTERBY-SMITH; THORPE; LOWE, 1999). Uma forma de fazê-lo é tratar das questões éticas em todas as etapas do seu projeto (descrição do problema e objetivos; coleta, análise e interpretação dos dados; redação e divulgação da pesquisa) e adotar um conjunto de práticas preventivas (CRESWELL, 2007; EASTERBY-SMITH; THORPE; LOWE, 1999; GOODWIN, 2009; STAKE, 2003; YIN, 2005), descritas a seguir:

a) Consentimento informado: elaboração de um formulário para os participantes assinarem, antecedendo o início da pesquisa, contendo: o direito de participar voluntariamente e desistir a qualquer momento; objetivo do estudo; procedimentos de estudo com quais dados serão coletados e como serão usados; direito de perguntar, ter uma cópia dos resultados e a privacidade respeitada; benefícios que o estudo pode resultar para a pessoa; assinatura do participante e do pesquisador concordando com os termos. Contudo, o pesquisador deve ter consciência que na abordagem qualitativa é difícil prever antecipadamente e com segurança e precisão que dados serão significativos, pela própria característica emergente com que surgem, e pode não ser possível interromper ou modificar a rotina de trabalho no ambiente de pesquisa.

b) Obtenção de permissão: documento formal para acesso aos participantes do estudo e aos locais de pesquisa determinando horário, duração e local.

c) Anonimato: proteger a verdadeira identidade dos participantes usando apelidos ou pseudônimos quando houver necessidades decorrentes de: tópicos polêmicos; a divulgação 
pode interferir nas ações subseqüentes das pessoas que foram estudadas; o caso relata um "tipo ideal". Somente se nenhuma alternativa for possível, o pesquisador deve pensar em manter o anonimato dos participantes e do estudo porque existem alguns fatores que dificultam o anonimato: o nível de detalhamento necessário para apoiar e situar as afirmativas de pesquisa pois o uso de nomes permite ao leitor recordar qualquer informação anterior da qual possa ter tomado conhecimento sobre o mesmo caso, fazer revisões e críticas; uso de número restrito de ambientes; número relativamente pequeno de participantes. Portanto, antes de se comprometer com o anonimato, deve-se considerar o nível que será possível alcançar usando alguns procedimentos como coletar dados em outro local para descaracterizar o ambiente que está sendo descrito e a identidade dos participantes e negociar a revelação de informações e identidades esclarecendo como serão apresentadas, citadas e interpretadas.

d) Confidencialidade: é a não revelação de informações pessoais quando foram dadas em confiança. É fundamental que o pesquisador seja claro no início quanto ao significado da confidencialidade no contexto da pesquisa qualitativa esclarecendo os limites da confidencialidade; se haverá apresentação e aprovação dos dados em estágios diferentes (transcrições, excertos); e que tipos de resultados podem ser esperados do estudo.

e) Destinação dos dados de estudo: arquivo, destruição ou devolução para que não sejam usados indevidamente.

f) Redação da pesquisa: não usar linguagem ofensiva ou palavras preconceituosas.

Todas as práticas éticas descritas são necessárias, todavia, elas são demasiadas rígidas e simplistas para lidar com casos reais visto que os conflitos organizacionais podem ser profundos e complexos (EASTERBY-SMITH; THORPE; LOWE, 1999). Isso requer do pesquisador alguma renúncia no grau de controle sobre: lugares e épocas de coleta de dados; temas que se tornam importantes; e tópicos que os participantes abordam.

Portanto, como afirma Goodwin $(2009$, p.74) “[...] a prática ética é mais um processo do que um desfecho; não pode ser determinada apenas pelo pesquisador, mas é alcançada por meio de negociações com participantes à luz das contingências de fazer a pesquisa em ambientes especiais.".

A pesquisa utilizou como estratégia de investigação o estudo de caso cujos entrevistados eram dirigentes de pequenas empresas. Portanto, diante das especificidades organizacionais envolvidas (hierarquia do entrevistado e porte da empresa), o relacionamento direto e próximo com os participantes e o acesso inevitável às informações pessoais e 
estratégicas do negócio, foram adotadas as seguintes práticas éticas, registradas no ofício (APÊNDICE B):

- Uso do consentimento informado: apresentação do objetivo da pesquisa, atividades planejadas, duração, tratamento das informações, disponibilização de acesso às notas de pesquisa e resultados parciais.

- Confidencialidade das informações: sigilo no tratamento e distribuição das informações coletadas.

- Anonimato: a decisão final em relação ao anonimato do informante será de escolha dos próprios.

Sintetizando, os principais aspectos metodológicos do presente trabalho de pesquisa foram:

- O investigador teve um papel importante, sendo ele próprio um "instrumento" de pesquisa e não somente um coadjuvante;

- Os dados foram coletados no seu ambiente natural, em uma amostra intencional, com a utilização de dois métodos de coleta - observação estruturada e análise documental - em um processo interativo tendo havido mudanças do primeiro para o segundo caso;

- Não houve intenção de buscar a generalização dos resultados;

- Buscou-se a explicação do comportamento das coisas e não da compreensão da dinâmica do Ser Humano, assim, o objeto de estudo foram os fatos (vistos e descritos) e não os fenômenos (apreendidos) tendo como temas comuns as ocorrências mais frequentes, gerais e universais e não ocorrências específicas; e

- Foi utilizada a estatística descritiva no tratamento e análise dos dados com os resultados apresentados em linguagem matemática (tabelas) e não apenas em descrições sobre as observações de campo. 


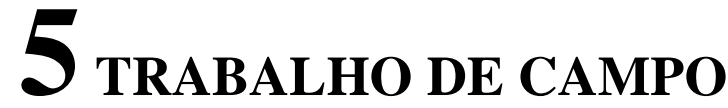

A estratégia de pesquisa contemplou o estudo de caso com a observação e o acompanhamento das atividades de dirigentes de pequenas empresas no seu ambiente natural de trabalho. Portanto, foram estudados dois casos em profundidade, sendo um dirigente acompanhado por cinco dias seguidos e o outro por quatro dias, ininterruptos.

O número de casos estudados e a duração do período de coleta foram suficientes para observação detalhada das atividades, análise intra e inter casos e a consequente contribuição para o estudo sobre a natureza do trabalho do dirigente da pequena empresa. Todavia, conforme será visto mais à frente, recomenda-se fortemente que novos estudos sejam feitos por outros pesquisadores.

\subsection{Informações Preliminares}

As empresas estudadas atenderam os critérios de seleção previamente definidos no planejamento da pesquisa, tais como:

- Ambas sediadas no estado de São Paulo;

- Não eram franquias ou filiais de médias ou grandes empresas;

- Empresas de pequeno porte segundo critérios de classificação quantitativos e qualitativos;

- Tinham mais de cinco anos de existência; e

- Faziam parte da rede de contatos do pesquisador.

O setor de atuação das empresas não era uma variável destacada para objeto de análise, entretanto, por pertencerem a setores diferentes (comércio e serviços), a oportunidade de contato permitiu ao pesquisador conviver e observar realidades organizacionais distintas nas perspectivas das estruturas organizacionais, ambientes de negócios, ritmos de trabalho e processos de gestão. Se o setor de atuação interfere na característica do trabalho do dirigente da pequena empresa e como isso se passa, poderá ser estudado em ocasiões futuras em outros trabalhos investigativos.

Conforme as premissas adotadas no planejamento da pesquisa, os dirigentes acompanhados nos estudos de caso foram escolhidos por concordarem voluntariamente em 
participar e serem sócio-dirigentes, ou seja, estando à frente de seus negócios. Sua faixa de idade está entre 37 e 45 anos, tendo os dois experiências de pelo menos cinco anos nos seus negócios, possibilitando algum grau mínimo de conhecimento e previsibilidade nas suas atividades e tarefas diárias.

\subsection{Preparativos para coleta de dados}

De acordo com o planejado para a etapa de pesquisa no campo, a coleta de dados foi realizada por um único pesquisador utilizando-se das técnicas de observação estruturada, entrevistas semi-estruturadas e análise documental, conforme protocolo de pesquisa (Apêndice C).

A coleta de dados teve como foco a essência do trabalho do dirigente da pequena empresa e não sua pessoa, contexto e aspectos periféricos (MINTZBERG, 1973), com atenção à freqüência e duração das atividades desenvolvidas durante o tempo de campo. Foram utilizadas notas pessoais do pesquisador para registro de comentários, observações e informações complementares.

Assim, três tipos de registros de dados foram feitos:

- Cronológico - anotação de cada atividade do dirigente e sua duração;

- Documentos recebidos e enviados; e

- Registro de contatos pessoais do dirigente durante sua rotina de trabalho - meios utilizados para contato, finalidade, participantes, local e iniciativa do contato.

Antecedendo o início da coleta de dados no campo, algumas providências foram tomadas visando assegurar a qualidade e a produtividade dos trabalhos, a saber:

- Formalização, por meio de ofício de pesquisa (Apêndice B), com o propósito de obter o consentimento dos dirigentes para os objetivos e coleta de dados da pesquisa;

- Diante da possibilidade de mudanças bruscas na programação dos dirigentes, uma semana antes do período de coleta no campo, foi confirmada a disponibilidade de agenda deles e de que se trataria de um período de trabalho o mais próximo possível das suas rotinas típicas, ainda que tivessem viagens, reuniões externas ou outros eventos dentro ou fora da empresa.

É importante realçar que o pesquisador atuava há pelo menos quatro anos como consultor organizacional para as duas empresas, logo, com amplo acesso aos dados 
preliminares para o entendimento da situação e o contexto em que o trabalho de pesquisa aconteceria, tais como:

- Histórico da empresa e dirigentes: surgimento da empresa e desenvolvimento dos negócios, fatos mais marcantes e mudanças societárias, expansão orgânica e estágio atual das atividades;

- O negócio: setor de atuação, produtos e serviços oferecidos, perfil dos clientes, fornecedores e concorrentes, fatores críticos de sucesso, processos de gestão primários e de apoio;

- Estrutura organizacional das empresas: principais funções e espaços ocupacionais, nomes e ocupações dos subordinados, localização física e nível hierárquico; e

- Características pessoais dos dirigentes: perfil pessoal, estilo de trabalho e rotinas, instrumentos de trabalho mais utilizados nas atividades, relações de poder, influência e proximidade com os públicos interno (subordinados) e externo (fornecedores, clientes e outras partes interessadas do negócio).

Esse conhecimento prévio proporcionou uma economia de tempo no levantamento de informações antecedentes ao início do trabalho de campo com benefícios durante toda a coleta diante da maior facilidade no registro das atividades dos dirigentes. A melhor identificação dos tipos de contato e eventos permitiu ao pesquisador direcionar sua energia e atenção maior na observação dos detalhes e complementos.

Contudo, a parte dos benefícios que a familiaridade do pesquisador com as empresas e dirigentes proporcionaria - decorrentes de sua condição profissional como consultor organizacional - havia o risco potencial que essa situação pudesse provocar algum viés no trabalho de coleta dos dados. Logo, alguns cuidados obrigatórios foram tomados como medidas cautelares antes e durante o período de campo:

- Reforço e lembrança contínua aos dirigentes dos objetivos do trabalho de pesquisa;

- O pesquisador não iria, durante o período de observação e coleta, em hipótese alguma, tomar a iniciativa para tratar de assuntos comuns ao trabalho de consultoria;

- Portanto, conforme previamente combinado com os dirigentes, na semana de atividade de observação não seria, e não foi, realizado consultoria e nem mesmo rápidas conversas sobre assuntos comuns da empresa e da consultoria; e 
- Disciplina e esforço contínuo do pesquisador para manter o foco e a concentração no trabalho, não fugindo do seu papel, portanto, não intervindo com a oferta de informações típicas do trabalho de consultoria.

\subsection{Execução da coleta de dados}

A providência inicial tomada pelo pesquisador, já no primeiro dia no campo, foi a ratificação com os dirigentes de pontos destacados de natureza ética e prática intrínsecos à pesquisa:

- A forma confidencial com que os dados coletados seriam tratados, preservando também o anonimato dos participantes;

- A finalidade da pesquisa não era promover juízo de valor sobre a forma como os dirigentes conduziam a gestão dos seus negócios, ou seja, avaliar sua produtividade, assertividade, eficácia nas decisões ou estilo pessoal. Foi reiterado que o propósito era somente levantar dados para entender e estudar as características do seu trabalho como dirigente de uma pequena empresa;

- Caso houvesse necessidade e a critério do dirigente, o pesquisador não participaria de eventos de caráter sigiloso, onde sua presença influenciasse os fatos ou pudesse causar algum tipo de constrangimento às partes, especialmente subordinados ou fornecedores;

- A importância de informar para os subordinados diretos sobre a presença do pesquisador e seus objetivos e que eles não seriam observados e avaliados no seu comportamento e desempenho; e

- Ao final do dia, seriam dedicados alguns minutos, fora do período de observação, para alinhamento dos trabalhos, esclarecimentos das partes, confirmação da agenda de trabalho do dirigente para o dia seguinte (local, horário, fatos excepcionais etc.) e obter opinião do dirigente sobre a atividade de coleta de dados.

As duas coletas de dados no campo aconteceram nos meses de abril e maio de 2011 com um intervalo de, aproximadamente, trinta dias entre elas. Isso possibilitou que o pesquisador identificasse oportunidades de melhoria no primeiro estudo e agisse proativamente adotando-as para o segundo. 
Uma das melhorias adotadas foi a ampliação de algumas categorias estabelecidas para o registro, por exemplo, o primeiro dirigente usava com muita freqüência o recurso tecnológico do software de comunicação instantânea via internet (chat) e mantinha um contato contínuo e estreito com fornecedores e subordinados nas suas atividades diárias.

Desta forma, foram incluídas novas categorias no segundo estudo de caso no tipo de atividade (Chat, Visita externa na empresa e Viagem de trabalho), uma nova categoria para participantes (Fornecedor) e três para iniciativa do contato (Subordinado, Fornecedor e Cliente).

$\mathrm{Na}$ categorização das atividades executadas pelos dirigentes adotou-se a premissa de que todo contato pessoal era uma forma de reunião, agendada ou não, independente se tivesse como propósito recebimento ou oferta de informação de natureza estratégica ou operacional.

Toda vez que uma atividade fosse realizada na sala do dirigente - assinatura de documentos, ligações telefônicas, navegação na internet, leitura de e-mails e análise de relatórios - era categorizada na dimensão Tipo de Atividade como Mesa de trabalho.

Nos dois casos estudados observou-se que os instrumentos utilizados nos sites de trabalho dos dirigentes eram muito semelhantes, variando na finalidade e intensidade. Além dos recursos mais tradicionais como mobiliário (mesas, cadeiras, armários), ambos faziam uso de computadores (desktop e notebook), softwares (planilhas eletrônicas, navegação na internet, comunicação instantânea e gerenciamento de $e$-mails), telefones fixos e celulares, calculadoras com operações básicas, fichas de cadastro e agendas em papel.

O acompanhamento dos dirigentes diariamente, incluindo as visitas internas e externas à empresa e viagens, causou, em um primeiro instante, alguma estranheza neles, sentindo-se ligeiramente desconfortáveis. Todavia, já no segundo dia, isso foi superado, ficando os dois muito à vontade e descontraídos; até mesmo em tom de brincadeira, o pesquisador era chamado de "sombra" ou "guarda-costas".

Outro fato a registrar é que o pesquisador dependia algumas vezes da informação dos dirigentes para identificar os contatos nas ligações telefônicas. O combinado é que o pesquisador perguntaria, contudo, com o passar dos dias e o convívio, os próprios dirigentes tomavam a iniciativa de informar. $\mathrm{Na}$ visão do pesquisador, esse fato poderia ser um indicador do interesse deles em contribuir com a qualidade e o êxito do trabalho investigativo.

Nos dois casos estudados, os dirigentes manifestaram positivamente curiosidade a respeito de como estavam se comportando, ou seja, o que os dados preliminares apresentavam 
a respeito das suas rotinas, número de contatos, tempo despendido no trabalho, ligações telefônicas, similaridades ou diferenças com as atividades de outros dirigentes já estudados.

A atitude do pesquisador foi evitar a antecipação de dados dispersos ou manifestar alguma opinião estruturada e apenas foi oferecido a eles, a título de reciprocidade e bom relacionamento, alguns dados quantitativos já tabulados. Em geral, os dirigentes ficavam satisfeitos e surpresos, especialmente número de ligações telefônicas diárias, quantidade de contatos pessoais e sua duração.

Ainda que fosse potencialmente possível acontecer durante a coleta dos dados, não houve o registro de nenhuma situação em que a presença do pesquisador pudesse gerar algum constrangimento para os dirigentes e subordinados. Todas as atividades de coleta transcorreram em um clima de tranqüilidade aonde os participantes contribuiriam grandemente com o sucesso da investigação.

Somente em dois episódios, durante um dos casos estudados, o pesquisador não esteve presencialmente com o dirigente visto que poderia interferir no êxito de uma negociação com um cliente, muito importante para empresa. De qualquer forma, foi permitido ao pesquisador ter conhecimento do tipo de atividade que estava sendo desenvolvida, o lugar, o tipo de participante, a duração dos eventos e o papel desempenhado pelo dirigente nas ocasiões.

Após a conclusão da coleta de dados, alguns procedimentos de natureza ética foram adotados como o envio de dois ofícios de agradecimento:

- Para os dirigentes das empresas pela sua participação e contribuição (Apêndice H); e

- Para o coordenador acadêmico da instituição de ensino superior, onde o pesquisador atuava na ocasião, pelo seu apoio e ações que permitiram a realização do trabalho (Apêndice I).

\subsection{Tabulação e análise dos dados}

Os dados foram coletados na sua forma bruta com o registro cronológico das atividades dos dirigentes minuto a minuto, por diversas vezes em intervalos menores (segundos), utilizando-se dos instrumentos previamente preparados (Apêndice D).

O planejamento inicial era tabular os dados e organizá-los diariamente, logo após a conclusão da sua obtenção, porém, nem sempre isso foi possível plenamente. Por algumas vezes, as atividades se estendiam para além do horário programado, invadindo o período da noite para coleta ou discussão de assuntos diversos, relacionados à pesquisa ou não. 
De qualquer forma, embora contasse com muitas anotações e "lembretes de rodapé", os dados foram tabulados no máximo quinze dias após sua coleta, evitando o risco da perda de informações e detalhes importantes.

Uma vez que os dados das atividades dos dirigentes foram registrados em papel durante a sua coleta, coube ao pesquisador transferi-los para o computador utilizando-se de software do tipo planilha eletrônica (layout no Apêndice E) dada a maior familiaridade com a ferramenta e a facilidade que seus recursos proporcionariam para a tabulação e posterior análise. Por exemplo: cálculo da duração das atividades, agrupamentos de dados, colocação em ordem crescente ou decrescente, cálculo de percentuais e somatórias, parciais e totais.

Depois de digitados individualmente e organizados nos campos específicos por dimensões e categorias, os dados eram conferidos para identificação e correção de possíveis erros de digitação e complementação de informações mais detalhadas.

Resumos para os dados Cronológicos (Apêndice F) e dos Contatos (Apêndice G) dos dirigentes foram criados e os valores transferidos para outra planilha a fim de resultarem em totalizações para análise individual (interna ao caso) e comparativa (entre casos), tomando como referência o modelo utilizado por Mintzberg (1973) em seu estudo, ajustado pelo pesquisador para as Categorias das atividades adicionadas ao trabalho:

- Análise Cronológica: Categorias; Mesa de Trabalho; Ligações Telefônicas; Reuniões agendadas; Reuniões Não agendadas; Visita Interna empresa; Visita Externa empresa; Viagem de Trabalho; e Intervalos.

- Análise dos Contatos: Categorias; Meios de Contato; Participantes; Iniciativa; e Lugar.

\subsection{Estudo de caso do Dirigente da Empresa Z}

\subsubsection{Descrição da Empresa Z}

O primeiro caso estudado é a empresa Z, classificada como de médio porte pelo critério quantitativo (SEBRAE, 2006), por ter 60 funcionários, podendo ser caracterizada também como empresa de pequeno porte, conforme apresentado no Quadro 3.6, porque nela foi possível identificar:

- Forte presença do proprietário ocupado no negócio;

- Poder decisório centralizado; 
- Estreito vínculo entre o proprietário e a empresa; e

- Relação de complementaridade com empresa de grande porte (fornecedores).

O surgimento da empresa $\mathrm{Z}$ se deu por uma oportunidade de mercado, tendo começado como uma microempresa em 2004 que vendia alimentos (basicamente frios e laticínios) diretamente para os consumidores e clientes no varejo e algumas lanchonetes, padarias, bares e restaurantes.

Nos últimos cinco anos, ela expandiu fortemente seus negócios, tendo a matriz localizada em uma pequena cidade no interior do estado de São Paulo e atuação regional em mais de trinta praças. A empresa $\mathrm{Z}$ tem uma filial no sul de Minas Gerais, adquirida há dois anos, onde atende mais de 20 cidades da região e opera com estrutura própria e relativo grau de independência operacional e financeira com a matriz.

O processo básico de operação do negócio corresponde às atividades de compra, venda e distribuição de produtos alimentícios (secos e congelados) e alguns itens descartáveis, destinados, principalmente, a clientes de micro e pequeno porte: bares, lanchonetes, restaurantes, pizzarias, hotéis, salgadeiras, cantinas escolares, lancheiros e mini-mercados.

Para execução de suas atividades estratégicas e operacionais a empresa mantém um relacionamento contínuo com dois grupos básicos de fornecedores, bastante diversificados no seu porte e origem:

- Suprimento de produtos para comercialização, em sua grande maioria, vindos de outras regiões e estados: indústrias de alimentos nacionais e estrangeiras, de micro a grandes multinacionais, distribuidores e representantes comerciais; e

- Serviços de apoio, em geral, presentes localmente: manutenção de instalações, equipamentos e veículos; tecnologia da informação; serviços financeiros; contabilidade; comunicação de marketing; assessoria jurídica; consultoria de gestão, entre outros.

A empresa detém o know-how necessário e é proprietária da maioria dos recursos materiais aplicados nas operações básicas de compra, venda, preparação e distribuição de produtos: instalações físicas (imóvel), veículos leves, máquinas e equipamentos de recebimento, movimentação, armazenagem e entrega dos produtos para os clientes.

Dois fatores críticos de sucesso se destacam no negócio de comercialização e distribuição de produtos alimentícios onde as margens de lucro são muito limitadas e demandam atenção e práticas de gestão diferenciadas: 
- Rigoroso controle dos gastos com funcionários e despesas administrativas; e

- Agilidade e eficiência na compra e venda das mercadorias para giro constante e acelerado dos produtos a fim de atingir o maior volume de vendas possível.

A empresa possui, entre matriz e filial, um quadro com 60 funcionários que desempenham espaços ocupacionais relativos às funções de vendas, finanças, contabilidade, logística e serviços gerais, operacionais e administrativos.

Há, predominantemente, uma especialização e distribuição formal de responsabilidades entre os funcionários com um nível hierárquico intermediário definido (supervisão) entre o dirigente da empresa e suas áreas operacionais. Assim, respondem diretamente para ele nove pessoas com níveis hierárquicos que variam entre supervisores comerciais, coordenação financeira, supervisão logística e funcionários da área operacional da matriz.

Caracteristicamente para o tipo de negócio que a empresa atua, o ambiente externo é objeto de constantes mudanças com eventos incontroláveis que a empresa age ou reage a eles, avaliados como:

- Ameaças - surgimento de novos entrantes, formais ou não; concorrência predatória de preços; variações nos custos das mercadorias ou outros itens estratégicos; elevação do grau de inadimplência de clientes; falta de mão de obra especializada, entre outros; e

- Oportunidades - abertura de novos pontos de venda gerando potenciais clientes; lançamento de novos produtos pelos fornecedores; ineficiência dos concorrentes no atendimento aos clientes comuns; mudança nos hábitos de alimentação da população, entre outros.

Do ponto de vista de formulação das suas estratégias, a empresa, na maior parte dos casos, adota ações reativas como forma de se defender das ameaças mais graves ou para explorar as oportunidades mais atraentes, sempre buscando fazê-lo com celeridade e eficiência.

Contudo, há episódios na história da empresa que as estratégias foram definidas e adotadas deliberadamente com o objetivo de crescimento orgânico dos negócios, por exemplo, na atuação em novos nichos e mercados geográficos ou na identificação e representação para comercialização de produtos líderes nas suas categorias. 


\subsubsection{Descrição do Dirigente da Empresa Z}

$\mathrm{O}$ dirigente da empresa $\mathrm{Z}$ é relativamente jovem, 37 anos, do sexo masculino, educação formal até o ensino médio, casado e tem três filhos. Sua experiência profissional sempre esteve ligada ao ramo de alimentação, desde muito jovem já trabalhava ajudando seus pais na lanchonete da família e, posteriormente, criou seu próprio negócio.

Está na direção da empresa $\mathrm{Z}$ desde sua fundação em 2004, dedicando-se exclusivamente a ela, não dividindo a gestão com outro sócio, apenas com seus nove subordinados diretos. Nota-se, por meio da observação do cotidiano do dirigente na empresa, uma centralização dos processos de gestão na sua pessoa com influência direta em toda organização, visto que estabelece seus objetivos, metas e planos, invariavelmente, refletindo suas próprias aspirações e motivações.

O dirigente executava pessoal e rotineiramente tarefas operacionais como as compras de mercadorias para revenda, desde o planejamento até a negociação e contratação. Evitava, sempre que possível, se ausentar da empresa em situações não planejadas ou por períodos mais longos (dois ou mais dias).

Em algumas circunstâncias, as pessoas físicas e jurídicas se confundiam, em especial, na disponibilização de recursos materiais e financeiros pessoais para a empresa.

Na ocasião da coleta dos dados para a pesquisa, o Dirigente $\mathrm{Z}$ estava instalado em uma sala localizada na área de logística, dentro do armazém da empresa, dividindo o espaço físico com duas subordinadas responsáveis pelo recebimento dos pedidos de venda, entrada de mercadorias no sistema de gestão, atendimento de ligações telefônicas e faturamento.

Anteriormente, já tinha compartilhado do mesmo espaço com os subordinados de finanças e vendas e relatou que o objetivo da decisão sempre foi estar próximo das operações onde tinha uma responsabilidade operacional direta.

Pode-se observar que o ambiente físico da empresa, e até mesmo o comportamental entre os subordinados, refletiam de certa forma traços da personalidade do seu dirigente; ainda que a natureza da atividade da empresa fosse extremamente dinâmica e sujeita a respostas rápidas e urgentes, os principais processos e o relacionamento informal transcorriam em um clima interno organizado, planejado e disciplinado.

Em geral, tentava-se evitar ao máximo possíveis improvisações, sobressaltos e agitações desnecessárias, exatamente da forma como o dirigente $\mathrm{Z}$ procurava conduzir sua 
rotina, seus negócios e sua vida pessoal: fazer o certo sempre da primeira vez para não ter de repetir e desperdiçar tempo e recursos materiais. A preparação e a organização eram vistas pelo dirigente $\mathrm{Z}$ como indispensáveis para o sucesso da empresa.

\subsection{Estudo de Caso do Dirigente da Empresa T}

\subsubsection{Descrição da Empresa T}

O segundo caso é a Empresa T, com seus 90 funcionários, classificada como de porte médio pelo critério quantitativo de número de funcionários e setor (SEBRAE, 2006). Todavia, nela também são encontradas características típicas de uma pequena empresa, conforme Quadro 3.6: forte presença dos proprietários no negócio; poder decisório centralizado nos dirigentes; estreito vínculo entre proprietários e empresa; e relação de complementaridade com clientes de grande porte (especialmente poder público).

A Empresa T foi criada dezessete anos atrás, após o desmembramento de um negócio de transporte de passageiros da família, quando dois sócios e irmãos decidiram ter sua própria empresa no mesmo segmento, localizada no sul do Estado de Minas Gerais.

Nos anos seguintes a sua criação, a empresa expandiu suas atividades em outros estados e municípios prestando serviços para o poder público municipal (concessões) e iniciativa privada (fretamento) com transporte urbano, rural, escolar e intermunicipal de passageiros. Mais recentemente, os sócios começaram a atuar com o comércio de postos de combustível nos Estados de São Paulo e Minas Gerais.

O processo básico de operação do negócio correspondia a conquista e cumprimento dos contratos e relacionamento com clientes e fornecedores por meio da gestão dos recursos próprios ou terceirizados:

- Humanos: mão de obra de chefes de garagem, motoristas, cobradores, mecânicos, administrativos;

- Tecnológicos: veículos, equipamentos, sistemas e processos de planejamento e controle;

- Conhecimento especializado: consultorias e assessorias jurídica, contábil, empresarial;

- Materiais e insumos: operacionais (combustível peças manutenção, pneus) e sua gestão; e

- Financeiros: capital de giro e investimentos. 
Dois fatores críticos de sucesso se destacavam no negócio da empresa: rigoroso controle dos custos operacionais que são $80 \%$ dos gastos correntes e a capacidade na gestão dos contratos de serviços com o poder público.

Havia, necessariamente, uma especialização e distribuição formal de tarefas entre os funcionários, todos se reportando diretamente ao Dirigente $\mathrm{T}$ : o gerente administrativo e operacional, o supervisor de recursos humanos, os chefes de garagem, chefes de tráfego, o mecânico-chefe e o comprador.

Uma vez conquistados os contratos de prestação de serviços, o foco principal estava no seu cumprimento dentro dos termos estabelecidos, contudo, era comum surgir eventos externos à empresa que precisavam ser avaliados e demandavam ações ou reações, por exemplo:

- Ameaças: interferências políticas; meios de transporte substitutos, concorrência predatória; variações nos custos dos principais insumos; falta de mão de obra especializada; e

- Oportunidades: abertura de licitações e concorrências; investimento do poder público e privado com ampliação na oferta de transporte para alunos e funcionários; instalação de novas empresas de grande porte nas regiões atendidas.

A empresa planejava e executava boa parte das suas atividades estratégicas de forma deliberada (especialmente o crescimento orgânico) e, em menor escala, adotava ações reativas como forma de se defender das ameaças mais graves ou explorar as oportunidades.

\subsubsection{Descrição do Dirigente da Empresa T}

O Dirigente T tem 45 anos, é do sexo masculino, com educação formal até o ensino médio, casado e tem três filhos. Desde muito cedo, sempre conviveu com a atividade de transporte de passageiros pela família ser proprietária de negócios no ramo.

Até 2005 dividia a direção da Empresa T com o cunhado que, após esta data, deixou de exercer essa função. Dedica-se prioritariamente ao negócio de transporte de passageiros, dividindo a gestão dos postos de combustível com a irmã (sócia).

No seu cotidiano, o dirigente era responsável pelas decisões estratégicas (negociações de contratos, novos negócios e investimentos); frequentemente, envolvia-se e executava diretamente tarefas relacionadas com assuntos ligados a compras, manutenção de veículos e contratação de subordinados de nível operacional e administrativo. 
O dirigente estava fisicamente instalado em uma sala localizada no centro administrativo da empresa, dividindo o espaço com o gerente operacional. Ele não era assistido por um subordinado dedicado exclusivamente para esse fim, sendo a recepcionista responsável pelo atendimento das ligações telefônicas externas.

O dirigente não tinha, normalmente, uma rotina rígida na sua agenda semanal e era muito comum viajar repentinamente com diferentes propósitos: visitar alguma filial, reuniões externas com clientes ou fornecedores, prospectar negócios e buscar informações de mercado. 


\section{APRESENTAÇÃo E ANÁLISE DOS DADOS}

Neste capítulo serão expostos os resultados da coleta e análise dos dados da pesquisa de campo, tendo como referência o trabalho de Mintzberg (1973) sobre o estudo da natureza do trabalho do administrador.

A apresentação será feita de forma individual, por caso estudado, e comparativamente entre os casos, contemplando a:

- Análise cronológica das atividades dos dirigentes: como despendem seu tempo, quantidade, duração e proporção do tempo;

- Análise dos contatos pessoais pelos meios usados: quantidade de contatos, lugares, duração, participantes, iniciativas de contato e proporção do tempo.

O objetivo não é somente fazer uma transcrição dos resultados, mas desenvolver algumas análises e tecer comentários a respeito dos resultados tendo em vista as demais informações, conhecimentos e observações realizadas pelo pesquisador durante a coleta de dados e que possibilitaram uma contribuição melhor para o entendimento dos fatos.

\subsection{Dirigente Z}

\subsubsection{Análise Cronológica das Atividades do Dirigente Z}

A Tabela 6.1 apresenta um resumo com as principais informações relativas aos aspectos cronológicos das atividades desempenhadas pelo Dirigente $\mathrm{Z}$ durante os cinco dias de observação de campo.

Primeiramente, pode-se observar que a jornada média não chega a oito horas diárias (07h46min), o que poderia sugerir que o trabalho não fosse muito intenso. Contudo, tomandose em consideração não somente a duração total da jornada, porém a quantidade de atividades realizadas por dia - em média 134 atividades - e que elas foram, predominantemente, de curta duração - 79\% com tempo inferior a três minutos - pode-se avaliar o ritmo acelerado que o trabalho do Dirigente $\mathrm{Z}$ acontece. 
E é exatamente essa a sensação que se tinha ao acompanhar a rotina do Dirigente Z: muitas coisas acontecendo em um ritmo intenso e breve (conforme exposto na Tabela 6.1, apenas 3\% das atividades tinham duração média acima de 60 minutos). Havia uma preocupação implícita com a produtividade de forma que o dia parecia ser curto para tudo que precisava ser feito, com velocidade, mas sem pressa.

Esse volume significativo de atividades diárias tem relação direta com as rotinas operacionais sob responsabilidade do Dirigente Z, como as compras de muitos itens de mercadorias para revenda que demandavam várias tarefas de recebimento e leitura de correspondências, contatos telefônicos, levantamento de informações, planejamento, negociação e contratação para um portfólio com 1.200 itens e muitos fornecedores.

Tabela 6.1: Resumo das Categorias Análise Cronológica Dirigente Z

\begin{tabular}{lc}
\hline \multicolumn{1}{c}{ Categorias } & Dirigente $\mathbf{Z}$ \\
Total Horas Trabalhadas & $38: 50: 05$ \\
Horas Trabalhadas/dia & $7: 46$ \\
Total de Correspondências/dia (recebidas e enviadas) & 42 \\
Média Correspondências processadas/dia & 8 \\
Total de Atividades & 672 \\
Atividades/dia & 134 \\
Duração Média Atividades - em Minutos & $0: 03$ \\
Proporção de Atividades com Duração Média inferior a 3 minutos & $79 \%$ \\
Proporção de Atividades com Duração Média inferior a 9 minutos & $93 \%$ \\
Proporção de Atividades com Duração Média acima de 60 & $3 \%$ \\
\hline
\end{tabular}

Quase um quarto do tempo do Dirigente Z, conforme a Tabela 6.2, era consumido com atividades realizadas na sua mesa de trabalho. Isso porque sua sala estava estrategicamente localizada dentro do armazém, na área de logística, o que facilitava seu contato com os subordinados, entre outras finalidades, para obter informações que apoiariam todo o processo de compra de mercadorias para revenda.

Também, estavam ali, ao alcance do dirigente, todos os recursos tecnológicos necessários - computador desktop, telefone fixo, softwares de gestão, planilhas eletrônicas, fichas cadastrais, gerenciamento de e-mail e acesso a internet - minimizando a necessidade de seu deslocamento para outros lugares da empresa.

Pode-se observar na Tabela 6.2 a brevidade das atividades, ou sessões, realizadas na mesa de trabalho do dirigente, pois eram, em média, de 02 minutos; abaixo da média geral de todas as atividades que era de 03 minutos (Tabela 6.1). 
Tabela 6.2: Atividades Mesa de Trabalho Dirigente Z

\begin{tabular}{lc}
\hline \multicolumn{1}{c}{ Mesa de Trabalho } & Dirigente $\mathbf{Z}$ \\
Número de Sessões & 217 \\
Número de Sessões/dia & 43 \\
Tempo na mesa de Trabalho - Total horas no período & $8: 53$ \\
Tempo na mesa de Trabalho - horas/dia & $1: 46$ \\
Duração Média - em Minutos & $0: 02$ \\
Proporção do Tempo & $23 \%$ \\
\hline
\end{tabular}

Uma proporção importante do tempo do Dirigente $\mathrm{Z}$ era dedicada para ligações telefônicas, feitas ou recebidas (13\%, conforme Tabela 6.3). Em média, foram 31 ligações diárias que absorviam quase uma hora da sua jornada e, em geral, de curtíssima duração (cada ligação consumia em torno de 01 minuto).

Novamente, esses resultados podem ser entendidos levando-se em consideração as atividades operacionais desempenhadas pelo dirigente e sua forma de conduzir seus contatos pessoais, de maneira objetiva e concisa.

Tabela 6.3: Ligações Telefônicas Dirigente Z

\begin{tabular}{lc}
\hline \multicolumn{1}{c}{ Ligações Telefônicas } & Dirigente $\mathbf{Z}$ \\
Número de Ligações & 155 \\
Número de Ligações/dia & 31 \\
Tempo ao Telefone - horas & $4: 56$ \\
Tempo ao Telefone - horas/dia & $0: 59$ \\
Duração Média - em Minutos & $0: 01$ \\
Proporção do Tempo & $13 \%$ \\
\hline
\end{tabular}

As reuniões agendadas, quantitativamente, não eram realizadas em grande número pelo Dirigente Z, conforme exposto na Tabela 6.4. Em parte, isso poderia ser explicado pelo caráter informal do ambiente de trabalho, pela proximidade física entre dirigente e seus subordinados com funções de gestão e pela forma dinâmica como os eventos aconteciam.

Tabela 6.4: Reuniões Agendadas Dirigente Z

\begin{tabular}{lc}
\hline \multicolumn{1}{c}{ Reuniões Agendadas } & Dirigente $\mathbf{Z}$ \\
Número de Reuniões & 21 \\
Número de Reuniões/dia & 4 \\
Tempo das Reuniões - horas & $5: 23$ \\
Tempo das Reuniões - horas/dia & $1: 04$ \\
Duração Média - em Minutos & $0: 15$ \\
Proporção do Tempo & $14 \%$ \\
\hline
\end{tabular}


Contudo, por durarem em média 15 minutos, as reuniões agendadas acabavam representando $14 \%$ do tempo total do dirigente, porém, pouco mais da metade do tempo destinado para as reuniões não agendadas, que representavam $27 \%$, conforme Tabela 6.5 .

Essas reuniões não agendadas caracterizavam-se por serem contatos breves, em torno de 03 minutos, que se destinavam, em sua maioria, a busca de informações, oferta de orientações ou decisões a serem executadas pelos subordinados.

Tabela 6.5: Reuniões Não Agendadas Dirigente Z

\begin{tabular}{lc}
\hline \multicolumn{1}{c}{ Reuniões Não Agendadas } & Dirigente Z \\
Número de Reuniões & 209 \\
Número de Reuniões/dia & 42 \\
Tempo das Reuniões - horas & $10: 36$ \\
Tempo das Reuniões - horas/dia & $2: 07$ \\
Duração Média - em Minutos & $0: 03$ \\
Proporção do Tempo & $27 \%$ \\
\hline
\end{tabular}

As visitas internas eram realizadas com pouca freqüência pelo Dirigente Z, em média duas por dia, com duração de 10 minutos cada uma. Logo, o tempo consumido na rotina diária era de apenas $5 \%$ do total (Tabela 6.6).

Na realidade, o dirigente percorria quase sempre o armazém ou o pátio de recebimento para verificar alguma mercadoria ou buscar uma informação que não poderia obter de outra forma. Era também, segundo o próprio dirigente, uma maneira de sair da sua sala para caminhar um pouco e relaxar, ver as pessoas e interagir com elas.

Tabela 6.6: Visita Interna Empresa Dirigente Z

\begin{tabular}{lc}
\hline \multicolumn{1}{c}{ Visita Interna Empresa } & Dirigente Z \\
Número de Visitas & 11 \\
Número de Visitas/dia & 2 \\
Tempo das Visitas - horas & $2: 00$ \\
Tempo das Visitas - horas/dia & $0: 24$ \\
Duração Média - em Minutos & $0: 10$ \\
Proporção do Tempo & $5 \%$ \\
\hline
\end{tabular}


Já as visitas externas, tinham uma freqüência mínima, tendo sido registradas apenas duas durante todo o período de observação (Tabela 6.7). Uma das vezes que aconteceu, quando da ida para a filial em Minas Gerais, onde o dirigente foi visitar as instalações de outras empresas que atuavam no mesmo setor e atividade de negócio.

\begin{tabular}{lc}
\multicolumn{2}{c}{ Tabela 6.7: Visita Externa Empresa Dirigente Z } \\
\hline \multicolumn{1}{c}{ Visita Externa Empresa } & Dirigente Z \\
Número de Visitas & 2 \\
Número de Visitas/dia & 0 \\
Tempo das Visitas - horas & $0: 32$ \\
Tempo das Visitas - horas/dia & $0: 06$ \\
Duração Média - em Minutos & $0: 16$ \\
Proporção do Tempo & $1 \%$ \\
\hline
\end{tabular}

O número de viagens realizadas foi de apenas três, considerando uma viagem cada trecho percorrido no dia em que o Dirigente $\mathrm{Z}$ visitou a filial da empresa em Minas Gerais e representou $10 \%$ do tempo total do período (Tabela 6.8).

Essa viagem acontece, em média a cada duas semanas e tem por objetivo verificar o andamento das atividades na filial e ter contato direto com os subordinados que lá trabalham.

\begin{tabular}{lc}
\multicolumn{2}{c}{ Tabela 6.8: Viagem de Trabalho Dirigente Z } \\
\hline \multicolumn{1}{c}{ Viagem de Trabalho } & Dirigente Z \\
Número de Viagens & 3 \\
Número de Viagens/dia & 1 \\
Tempo das Viagens - horas & $3: 45$ \\
Tempo das Viagens - horas/dia & $0: 45$ \\
Duração Média - em Minutos & $1: 15$ \\
Proporção do Tempo & $10 \%$ \\
\hline
\end{tabular}

O Dirigente $\mathrm{Z}$ tinha por hábito fazer em torno de três intervalos por dia, destinados a tomar café com todos os subordinados na cozinha da empresa, algo já institucionalizado, portanto, fazendo parte do cotidiano.

Conforme a Tabela 6.9, o tempo médio de duração dos intervalos é de 6 minutos, acima da média geral das atividades, mas relativamente curto se considerarmos que nessas ocasiões o Dirigente $\mathrm{Z}$ aproveitava para relaxar, conversar, experimentar produtos novos, conseguir e oferecer informações pessoalmente. Quando viajou para sua filial manteve a rotina com os intervalos para as mesmas finalidades. 
Tabela 6.9: Intervalos Dirigente Z

\begin{tabular}{lc}
\hline \multicolumn{1}{c}{ Intervalos } & Dirigente Z \\
Número de Intervalos & 13 \\
Número de Intervalos/dia & 3 \\
Tempo dos Intervalos - horas & $1: 28$ \\
Tempo dos Intervalos - horas/dia & $0: 17$ \\
Duração Média - em Minutos & $0: 06$ \\
Proporção do Tempo & $4 \%$ \\
\hline
\end{tabular}

\subsubsection{Análise dos Contatos Pessoais do Dirigente Z}

Em média, o Dirigente $\mathrm{Z}$ realiza 45 contatos pessoais diariamente (Tabela 6.10), com duração média de 02 minutos, predominantemente por meio de ligações telefônicas/chat e reuniões não agendadas (Tabela 6.11), que juntos representam $92 \%$ das atividades e $69 \%$ do tempo, respectivamente.

Pode-se observar também que as reuniões agendadas e as visitas internas na empresa representavam juntas apenas $8 \%$ do número de atividades realizadas no dia; em termos de tempo, por terem uma duração acima da média, consumiam 32\% (Tabela 6.11).

Tabela 6.10: Resumo Contatos Pessoais Dirigente Z

\begin{tabular}{lc}
\hline \multicolumn{1}{c}{ Categorias } & Dirigente Z \\
Horas Contato Pessoal / dia & $2: 22$ \\
Média Contato Pessoal / dia & 45 \\
\hline
\end{tabular}

Tabela 6.11: Meios de Contato Pessoal Dirigente Z

\begin{tabular}{lcc}
\hline \multicolumn{1}{c}{$\begin{array}{c}\text { Meios : Percentual de Contatos / } \\
\quad \text { Percentual do Tempo }\end{array}$} & Dirigente Z \\
\hline $\begin{array}{l}\text { Ligações Telefônicas e Chat } \\
\text { (Sistema Comunicação Instantânea) }\end{array}$ & $44 \%$ & $24 \%$ \\
Reuniões Agendadas & $5 \%$ & $23 \%$ \\
Reuniões Não Agendadas & $48 \%$ & $45 \%$ \\
Visita Interna Empresa & $3 \%$ & $9 \%$ \\
\hline
\end{tabular}

Os subordinados e fornecedores somados representavam $94 \%$ das atividades e $88 \%$ do tempo destinado aos contatos pessoais do Dirigente $\mathrm{Z}$; os clientes apenas $1 \%$ do tempo (Tabela 6.12). Esses dados podem ser entendidos a partir da combinação de alguns fatores já mencionados: suas responsabilidades por compras, raramente ele faz venda direta para clientes e sua proximidade física com a maioria dos subordinados na matriz.

Por outro lado, como a característica do seu negócio são as vendas diretas ao varejo, por meio da equipe comercial, poucas são as oportunidades de contato pessoal do dirigente 
com seus clientes na sede da empresa; para se relacionar com eles, o Dirigente $\mathrm{Z}$ teria de sair propositalmente da sua empresa ou telefonar, já que seus principais meios de contato são esses, conforme visto anteriormente.

\begin{tabular}{lcc}
\multicolumn{2}{c}{ Tabela 6.12: Participantes Contato Pessoal Dirigente Z } \\
\hline \multicolumn{1}{c}{ Participantes: Percentual de } & Dirigente Z \\
Contatos / Percentual do Tempo & $69 \%$ & $66 \%$ \\
Subordinados & $2 \%$ & $1 \%$ \\
Clientes & $25 \%$ & $22 \%$ \\
Fornecedores & $4 \%$ & $12 \%$ \\
Outros &
\end{tabular}

A iniciativa dos contatos partia, na maioria das vezes, do próprio dirigente e em segundo momento dos subordinados com $65 \%$ e $24 \%$, respectivamente, tendo como principal lugar seu escritório, localizado estrategicamente na área logística (Tabelas 6.13 e 6.14).

Em termos de tempo, os contatos pessoais realizados no escritório do dirigente absorviam $40 \%$ do tempo, seguido por outros lugares da empresa (cozinha, recepção, pátio) com $25 \%$ do total (Tabela 6.14)

\begin{tabular}{lc}
\multicolumn{2}{c}{ Tabela 6.13: Iniciativa Contato Pessoal Dirigente Z } \\
\hline \multicolumn{1}{c}{ Iniciativa: Percentual de Contatos } & Dirigente Z \\
Própria & $65 \%$ \\
Planejada & $0 \%$ \\
Subordinados & $24 \%$ \\
Fornecedor & $10 \%$ \\
Cliente & $0 \%$ \\
Outras & $0 \%$ \\
\hline
\end{tabular}

Tabela 6.14: Lugar Contato Pes soal Dirigente Z

\begin{tabular}{lcc}
\hline $\begin{array}{c}\text { Lugar: Percentual de Contatos / } \\
\text { Percentual do Tempo }\end{array}$ & Dirigente Z \\
\hline Escritório Dirigente & $76 \%$ & $40 \%$ \\
Escritório Subordinado & $13 \%$ & $17 \%$ \\
Área Operacional & $2 \%$ & $5 \%$ \\
Fora da Empresa & $1 \%$ & $12 \%$ \\
Outro Lugar Empresa & $8 \%$ & $25 \%$ \\
\hline
\end{tabular}




\subsection{Dirigente T}

\subsubsection{Análise Cronológica das Atividades do Dirigente T}

Em um dia típico, o Dirigente T trabalha 09 horas, processa seis correspondências $(e-$ mails recebidos e enviados), executa 43 atividades, que duram 12 minutos cada, porém, quase metade delas (48\%) consome até 03 minutos (Tabela 6.15).

\begin{tabular}{lc}
\multicolumn{1}{c}{ Tabela 6.15: Resumo das Categorias Análise Cronológica Dirigente T } \\
\hline \multicolumn{1}{c}{ Carias } & Dirigente T \\
Total Horas Trabalhadas & $36: 20: 45$ \\
Horas Trabalhadas/dia & $9: 05$ \\
Total de Correspondências/dia (recebidas e & 24 \\
Média Correspondências processadas/dia & 6 \\
Total de Atividades & 172 \\
Atividades/dia & 43 \\
Duração Média Atividades - em Minutos & $0: 12$ \\
Proporção de Atividades com Duração Média & $48 \%$ \\
inferior a 3 minutos & \\
Proporção de Atividades com Duração Média & $65 \%$ \\
inferior a 9 minutos & \\
Proporção de Atividades com Duração Média acima & $8 \%$ \\
de 60 minutos &
\end{tabular}

Em torno de $7 \%$ do seu tempo era gasto na sua mesa de trabalho, pouco mais de 30 minutos por dia, com atividades que duravam 04 minutos (Tabela 6.16). De certa forma, essa a percepção que o pesquisador tinha durante a observação de campo, pois, a permanência do Dirigente $\mathrm{T}$ em seu escritório em atividades na sua mesa de trabalho era somente para fazer o necessário (ler e-mails e assinar documentos, basicamente).

Tabela 6.16: Atividades Mesa de Trabalho Dirigente T

\begin{tabular}{lc}
\hline \multicolumn{1}{c}{ Mesa de Trabalho } & Dirigente T \\
Número de Sessões & 34 \\
Número de Sessões/dia & 9 \\
Tempo na mesa de Trabalho - Total horas no período & $2: 26$ \\
Tempo na mesa de Trabalho - horas/dia & $0: 36$ \\
Duração Média - em Minutos & $0: 04$ \\
Proporção do Tempo & $7 \%$ \\
\hline
\end{tabular}

O telefone era um instrumento de trabalho muito utilizado pelo Dirigente $\mathrm{T}$ na sua rotina diária, representando $8 \%$ do seu tempo para uma média de 13 ligações, durando cada uma 03 minutos; portanto, de curta duração considerando o tempo médio das atividades de 12 minutos (Tabela 6.17). 
Tabela 6.17: Ligações Telefônicas Dirigente T

\begin{tabular}{lc}
\hline \multicolumn{1}{c}{ Ligações Telefônicas } & Dirigente T \\
Número de Ligações & 52 \\
Número de Ligações/dia & 13 \\
Tempo ao Telefone - horas & $2: 44$ \\
Tempo ao Telefone - horas/dia & $0: 41$ \\
Duração Média - em Minutos & $0: 03$ \\
Proporção do Tempo & $8 \%$ \\
\hline
\end{tabular}

Em média, 45\% do tempo do Dirigente T era despendido em reuniões, agendadas ou não, porém, com uma grande variação entre elas no seu tempo de duração: 39 minutos e 09 minutos, respectivamente (Tabelas 6.18 e 6.19). Geralmente, as reuniões agendadas ocorriam com clientes e fornecedores e envolviam negociações de contratos e assuntos estratégicos, o que poderia explicar sua maior duração.

Tabela 6.18: Reuniões Agendadas Dirigente T

\begin{tabular}{lc}
\hline \multicolumn{1}{c}{ Reuniões Agendadas } & Dirigente T \\
Número de Reuniões & 14 \\
Número de Reuniões/dia & 4 \\
Tempo das Reuniões - horas & $9: 12$ \\
Tempo das Reuniões - horas/dia & $2: 18$ \\
Duração Média - em Minutos & $0: 39$ \\
Proporção do Tempo & $25 \%$ \\
\hline
\end{tabular}

Tabela 6.19: Reuniões Não Agendadas Dirigente T

\begin{tabular}{lc}
\hline \multicolumn{1}{c}{ Reuniões Não Agendadas } & Dirigente T \\
Número de Reuniões & 44 \\
Número de Reuniões/dia & 11 \\
Tempo das Reuniões - horas & $7: 07$ \\
Tempo das Reuniões - horas/dia & $1: 46$ \\
Duração Média - em Minutos & $0: 09$ \\
Proporção do Tempo & $20 \%$ \\
\hline
\end{tabular}

Raramente o Dirigente $\mathrm{T}$ realizava visitas internas e externas na empresa durante o período de observação (Tabelas 6.20 e 6.21). Como dois exemplos a citar, em uma ocasião ele visitou um terreno recém adquirido com a finalidade de expandir os negócios e outra esteve na área operacional para verificar um veículo e conversar com um subordinado direto.

Tabela 6.20: Visita Interna Empresa Dirigente T

\begin{tabular}{lc}
\hline \multicolumn{1}{c}{ Visita Interna Empresa } & Dirigente T \\
Número de Visitas & 1 \\
Tempo das Visitas - horas & $0: 00$ \\
Tempo das Visitas - horas/dia & $0: 00$ \\
Proporção do Tempo & $0 \%$ \\
\hline
\end{tabular}


Tabela 6.21: Visita Externa Empresa Dirigente T

\begin{tabular}{lc}
\hline \multicolumn{1}{c}{ Visita Externa Empresa } & Dirigente T \\
Número de Visitas & 2 \\
Número de Visitas/dia & 1 \\
Tempo das Visitas - horas & $0: 41$ \\
Tempo das Visitas - horas/dia & $0: 10$ \\
Duração Média - em Minutos & $0: 20$ \\
Proporção do Tempo & $2 \%$ \\
\hline
\end{tabular}

As viagens tinham um papel importante e faziam parte da rotina do Dirigente T. Como a empresa opera em diferentes cidades na região e fora do estado, usualmente, as reuniões com os clientes eram realizadas presencialmente, implicando no deslocamento constante. Elas consumiram em média 24\% do tempo com uma duração aproximada de 01 hora (Tabela 6.22.

O pesquisador, assim como o gerente operacional, acompanhou o dirigente em todas as viagens realizadas e pode observar que, muito mais do que um simples deslocamento, elas eram uma oportunidade para que eles tratassem dos mais diferentes assuntos relativos à empresa, especialmente os estratégicos, planejando ações e avaliando seus resultados.

\begin{tabular}{lc}
\multicolumn{2}{c}{ Tabela 6.22: Viagem de Trabalho Dirigente T } \\
\hline \multicolumn{1}{c}{ Viagem de Trabalho } & Dirigente T \\
Número de Viagens & 9 \\
Número de Viagens/dia & 2 \\
Tempo das Viagens - horas & $8: 53$ \\
Tempo das Viagens - horas/dia & $2: 13$ \\
Duração Média - em Minutos & $0: 59$ \\
Proporção do Tempo & $24 \%$ \\
\hline
\end{tabular}

Os intervalos eram bastante comuns, três por dia representando $10 \%$ do tempo, e eram usados como uma pausa para um cafezinho durante a jornada (Tabela 6.23). A empresa tem um local específico, planejado para este fim, com estrutura para receber visitantes externos, a sócia e alguns subordinados diretos.

Tabela 6.23: Intervalos Dirigente T

\begin{tabular}{lc}
\hline \multicolumn{1}{c}{ Intervalos } & Dirigente T \\
Número de Intervalos & 13 \\
Número de Intervalos/dia & 3 \\
Tempo dos Intervalos - horas & $3: 45$ \\
Tempo dos Intervalos - horas/dia & $0: 56$ \\
Duração Média - em Minutos & $0: 17$ \\
Proporção do Tempo & $10 \%$ \\
\hline
\end{tabular}




\subsubsection{Análise dos Contatos Pessoais do Dirigente T}

Os contatos pessoais ocorriam, em média, 14 vezes ao dia, principalmente por meio de ligações telefônicas e reuniões não agendadas, $47 \%$ e $40 \%$ do total, respectivamente, conforme Tabela 6.24. Contudo, as reuniões agendadas representavam quase metade do tempo gasto total (48\%), conforme consta na Tabela 6.25. Se considerarmos as reuniões não agendadas conjuntamente (37\%), pode-se concluir que quase $86 \%$ dos contatos pessoais aconteciam presencialmente, o que demonstra a preferência do Dirigente $\mathrm{T}$ por esses meios.

\begin{tabular}{lc} 
Tabela 6.24: Resumo Contatos Pessoais Dirigente T \\
\hline \multicolumn{1}{c}{ Categorias } & Dirigente T \\
Horas Contato Pessoal / dia & $4: 24$ \\
Média Contato Pessoal / dia & 14 \\
\hline
\end{tabular}

Tabela 6.25: Meios de Contato Pessoal Dirigente T

\begin{tabular}{lcc}
\hline \multicolumn{1}{c}{$\begin{array}{c}\text { Meios: Percentual de Contatos / } \\
\text { Percentual do Tempo }\end{array}$} & Dirigente T \\
Ligações Telefônicas e Chat (Sistema & $47 \%$ & $14 \%$ \\
Comunicação Instantânea) & & \\
Reuniões Agendadas & $13 \%$ & $48 \%$ \\
Reuniões Não Agendadas & $40 \%$ & $37 \%$ \\
Visita Interna Empresa & $1 \%$ & $0 \%$ \\
\hline
\end{tabular}

Os principais participantes nos contatos pessoais foram os subordinados e fornecedores (juntos somam 75\%), considerando a quantidade deles, todavia, em termos de tempo gasto, quase $76 \%$ estavam concentrados entre subordinados e clientes $(57 \%$ e $18 \%$, respectivamente, conforme Tabela 6.26). Poder-se-ia concluir que, embora os fornecedores tivessem uma presença quantitativa maior que os clientes, em termos de tempo, o Dirigente T dedicava-se mais no contato com seus clientes, o que era possível, pelo perfil deles (grandes empresas e poder público).

Embora os subordinados tenham presença importante nos contatos pessoais, a iniciativa partia, em $65 \%$ das vezes, do próprio dirigente e apenas 22\% deles (Tabela 6.27).

Tabela 6.26: Participantes Contato Pessoal Dirigente T

\begin{tabular}{lcc}
\hline \multicolumn{1}{c}{$\begin{array}{c}\text { Participantes: Percentual de Contatos / } \\
\text { Percentual do Tempo }\end{array}$} & \multicolumn{2}{c}{ Dirigente T } \\
Subordinados & $48 \%$ & $57 \%$ \\
Clientes & $6 \%$ & $18 \%$ \\
Fornecedores & $28 \%$ & $12 \%$ \\
Outros & $19 \%$ & $12 \%$ \\
\hline
\end{tabular}




\begin{tabular}{lc}
\multicolumn{2}{c}{ Tabela 6.27: Iniciativa Contato Pessoal Dirigente T } \\
\hline \multicolumn{1}{c}{ Iniciativa: Percentual de Contatos } & Dirigente T \\
Própria & $65 \%$ \\
Planejada & $0 \%$ \\
Subordinados & $22 \%$ \\
Fornecedor & $2 \%$ \\
Cliente & $3 \%$ \\
Outras & $7 \%$ \\
\hline
\end{tabular}

$\mathrm{O}$ escritório do dirigente era o local onde a maioria absoluta dos contatos pessoais acontecia (70\%), contudo, a maior parcela de tempo foi despendida fora da empresa (58\%), especialmente com reuniões agendadas ou não com fornecedores e clientes, como consta na Tabela 6.28. Raramente, apenas 3\% das vezes e do tempo, os contatos pessoais aconteciam no escritório do subordinado.

Tabela 6.28: Lugar Contato Pes soal Dirigente T

\begin{tabular}{lcc}
\hline \multicolumn{1}{c}{$\begin{array}{c}\text { Lugar: Percentual de Contatos / } \\
\text { Percentual do Tempo }\end{array}$} & \multicolumn{2}{c}{ Dirigente T } \\
Escritório Dirigente & $70 \%$ & $33 \%$ \\
Escritório Subordinado & $3 \%$ & $3 \%$ \\
Área Operacional & $1 \%$ & $2 \%$ \\
Fora da Empresa & $22 \%$ & $59 \%$ \\
Outro Lugar Empresa & $4 \%$ & $2 \%$ \\
\hline
\end{tabular}

\subsection{Análise Comparativa entre os Casos dos Dirigentes Z e T}

\subsubsection{Análise Cronológica das Atividades dos Dirigentes Z e T}

A Tabela 6.29 apresenta os dados comparativos entre os dois casos estudados e permite visualizar semelhanças e diferenças entre eles no tocante as atividades desenvolvidas.

De certa forma, eles têm em comum a jornada diária (entre 08 e 09 horas), o número de correspondências processadas e a baixa representatividade das atividades de longa duração (acima de 60 minutos de duração) como característica do seu trabalho.

Porém, na Tabela 6.30, ficam evidentes algumas diferenças significativas quando se tratam da quantidade de atividades executadas por dia (134 para o Dirigente Z e 43 para o T) e sua duração média (03 minutos para o Dirigente $\mathrm{Z}$ e 12 para o T). 
Tabela 6.29: Resumo das Categorias Análise Cronológica Dirigentes Z e T

\begin{tabular}{lcc}
\hline \multicolumn{1}{c}{ Categorias } & Dirigente Z & Dirigente T \\
Horas Trabalhadas/dia & $7: 46$ & $9: 05$ \\
Média Correspondências processadas/dia & 8 & 6 \\
Atividades/dia & 134 & 43 \\
$\begin{array}{l}\text { Duração Média Atividades - em Minutos } \\
\text { Proporção de Atividades com Duração Média inferior }\end{array}$ & $0: 03$ & $0: 12$ \\
$\begin{array}{l}\text { a 3 minutos } \\
\text { Proporção de Atividades com Duração Média inferior }\end{array}$ & $79 \%$ & $48 \%$ \\
$\begin{array}{l}\text { a 9 minutos } \\
\text { Proporção de Atividades com Duração Média acima } \\
\text { de 60 minutos }\end{array}$ & $3 \%$ & $65 \%$ \\
\hline
\end{tabular}

$\mathrm{O}$ Dirigente $\mathrm{Z}$ executa mais atividades na sua mesa de trabalho e permanece mais tempo nela, comparativamente com o Dirigente T. Mas, suas atividades são mais breves com uma duração média de 02 minutos contra 04 minutos do Dirigente T.

Tabela 6.30: Atividades Mesa de Trabalho Dirigentes Z e T

\begin{tabular}{lcc}
\hline \multicolumn{1}{c}{ Mesa de Trabalho } & Dirigente Z & Dirigente T \\
Número de Sessões/dia & 43 & 9 \\
Tempo na mesa de Trabalho - horas/dia & $1: 46$ & $0: 36$ \\
Duração Média - em Minutos & $0: 02$ & $0: 04$ \\
Proporção do Tempo & $23 \%$ & $7 \%$ \\
\hline
\end{tabular}

O uso do telefone, conforme visto em cada caso, é uma atividade presente na rotina dos dois dirigentes e, embora a proporção de tempo gasto para os dois seja relativamente próxima (13\% para Z e $8 \%$ para $\mathrm{T}$ ), há diferenças na quantidade de ligações e duração média, conforme Tabela 6.31 .

$\mathrm{O}$ Dirigente $\mathrm{Z}$ usa o telefone (entre ligações feitas e recebidas) três vezes mais que o Dirigente T, mas gasta em cada uma um terço do tempo, relativamente. A explicação pode estar na finalidade do uso, por exemplo, o Dirigente $\mathrm{Z}$ concentra-se mais no envio e recebimento de informações para compras de mercadorias - foco claro e conciso - enquanto o Dirigente $\mathrm{T}$ trata de assuntos mais complexos, muitas vezes estratégicos. Mas, além desse aspecto, não se deve descartar a diferença de estilo de comunicação entre eles.

\begin{tabular}{lcc}
\multicolumn{3}{c}{ Tabela 6.31: Ligações Telefônicas Dirigentes Z e T } \\
\hline \multicolumn{1}{c}{ Ligações Telefônicas } & Dirigente Z & Dirigente T \\
Número de Ligações/dia & 31 & 13 \\
Tempo ao Telefone - horas/dia & $0: 59$ & $0: 41$ \\
Duração Média - em Minutos & $0: 01$ & $0: 03$ \\
Proporção do Tempo & $13 \%$ & $8 \%$ \\
\hline
\end{tabular}

A quantidade média de reuniões agendadas por dia é exatamente a mesma entre os dois dirigentes (Tabela 6.32), todavia, as semelhanças não vão além disso. O tempo gasto 
diariamente com as reuniões agendadas, a duração média e a proporção de tempo são inteiramente diferentes, como pode ser observado na Tabela 6.32 .

\begin{tabular}{lcc}
\multicolumn{3}{c}{ Tabela 6.32: Reuniões Agendadas Dirigentes Z e T } \\
\hline \multicolumn{1}{c}{ Reuniões Agendadas } & Dirigente Z & Dirigente T \\
Número de Reuniões/dia & 4 & 4 \\
Tempo das Reuniões - horas/dia & $1: 04$ & $2: 18$ \\
Duração Média - em Minutos & $0: 15$ & $0: 39$ \\
Proporção do Tempo & $14 \%$ & $25 \%$ \\
\hline
\end{tabular}

Novamente, há mais diferenças do que semelhanças entre os Dirigentes $Z$ e $T$ tratando-se das reuniões não agendadas. A Tabela 6.33 mostra que, enquanto o Dirigente Z tem em média 42 sessões por dia, para o Dirigente T esse número é quase quatro vezes menor (11). Além disso, a diferença na duração média das reuniões é expressiva, variando entre 03 minutos (Dirigente Z) e 09 minutos (Dirigente T).

De qualquer maneira, a proporção que as reuniões não agendadas ocupam do tempo dos dirigentes está na faixa de 20 a 27\% (T e Z, respectivamente).

Tabela 6.33: Reuniões Não Agendadas Dirigentes Z e T

\begin{tabular}{lcc}
\hline \multicolumn{1}{c}{ Reuniões Não Agendadas } & Dirigente Z & Dirigente T \\
Número de Reuniões/dia & 42 & 11 \\
Tempo das Reuniões - horas/dia & $2: 07$ & $1: 46$ \\
Duração Média - em Minutos & $0: 03$ & $0: 09$ \\
Proporção do Tempo & $27 \%$ & $20 \%$ \\
\hline
\end{tabular}

As visitas, internas e externas, não são executadas com freqüência por nenhum dos dois dirigentes (Tabelas 6.34 e 6.35), porém, quando acontecem, tem uma duração acima da média das demais atividades. Especialmente as visitas externas, o que é compreensível, pois não faria muito sentido sair da empresa para ficar apenas 03 minutos, por exemplo.

Tabela 6.34: Visita Interna Empresa Dirigentes Z e T

\begin{tabular}{lcc}
\hline \multicolumn{1}{c}{ Visita Interna Empresa } & Dirigente $\mathbf{Z}$ & Dirigente T \\
Número de Visitas/dia & 2 & 0 \\
Tempo das Visitas - horas/dia & $0: 24$ & $0: 00$ \\
Duração Média - em Minutos & $0: 10$ & $0: 00$ \\
Proporção do Tempo & $5 \%$ & $0 \%$ \\
\hline
\end{tabular}


Tabela 6.35: Visita Externa Empresa Dirigentes Z e T

\begin{tabular}{lcc}
\hline \multicolumn{1}{c}{ Visita Externa Empresa } & Dirigente Z & Dirigente T \\
Número de Visitas/dia & 0 & 1 \\
Tempo das Visitas - horas/dia & $0: 06$ & $0: 10$ \\
Duração Média - em Minutos & $0: 16$ & $0: 20$ \\
Proporção do Tempo & $1 \%$ & $2 \%$ \\
\hline
\end{tabular}

Embora o número e o tempo de duração das viagens sejam próximos e a proporção do tempo que representam sejam significativas (10 e 24\%, Dirigentes $\mathrm{Z}$ e $\mathrm{T}$ respectivamente, conforme Tabela 6.36), os demais aspectos variariam muito.

Dirigente $\mathrm{Z}$ fez sua viagem para a filial de forma programada e com antecedência tendo por finalidade reunir-se com seus subordinados locais e acompanhar os resultados da operação, o que ocorre quinzenalmente com bastante regularidade. Para o Dirigente T, as viagens são uma constante, podendo alterar muito de propósito, lugar, meios de locomoção, duração, horários e contatos a serem estabelecidos.

\begin{tabular}{lcc}
\multicolumn{3}{c}{ Tabela 6.36: Viagem de Trabalho Dirigentes Z e T } \\
\hline \multicolumn{1}{c}{ Viagem de Trabalho } & Dirigente Z & Dirigente T \\
Número de Viagens/dia & 1 & 2 \\
Tempo das Viagens - horas/dia & $0: 45$ & $2: 13$ \\
Duração Média - em Minutos & $1: 15$ & $0: 59$ \\
Proporção do Tempo & $10 \%$ & $24 \%$ \\
\hline
\end{tabular}

Os dois dirigentes têm situações semelhantes sobre a presença e finalidade dos intervalos nas suas rotinas diárias: a quantidade é a mesma (03, conforme Tabela 6.37) e não são de longa duração. Para os eles, a finalidade dos intervalos está relacionada com uma pausa para descanso, ocorrem em áreas especificas (cozinha e copa) e são a oportunidade de relacionamento social para troca de informações com subordinados, fornecedores e clientes.

Tabela 6.37: Intervalos Dirigentes T e Z

\begin{tabular}{lcc}
\hline \multicolumn{1}{c}{ Intervalos } & Dirigente $\mathbf{Z}$ & Dirigente T \\
Número de Intervalos/dia & 3 & 3 \\
Tempo dos Intervalos - horas/dia & $0: 17$ & $0: 56$ \\
Duração Média - em Minutos & $0: 06$ & $0: 17$ \\
Proporção do Tempo & $4 \%$ & $10 \%$ \\
\hline
\end{tabular}

\subsubsection{Análise dos Contatos Pessoais dos Dirigentes Z e T}

A média de contatos pessoais por dia difere muito entre os Dirigentes Z e T (45 e 14, respectivamente, de acordo com a Tabela 6.38), porém, para ambos, há predominância pelos 
meios telefone/chat e reuniões não agendadas (Tabela 6.39), preferidos pela sua informalidade, agilidade e praticidade para a comunicação interpessoal.

Tabela 6.38: Resumo das Categorias Contatos Pessoais Dirigentes Z e T

\begin{tabular}{lcc}
\hline Categorias & Dirigente Z & Dirigente T \\
Horas Contato Pessoal / dia & $2: 22$ & $4: 24$ \\
Média Contato Pessoal / dia & 45 & 14 \\
\hline
\end{tabular}

Tabela 6.39: Meios de Contato Pessoal Dirigentes Z e T

\begin{tabular}{lcccc}
\hline \multicolumn{1}{c}{$\begin{array}{c}\text { Meios: Percentual de Contatos / } \\
\text { Percentual do Tempo }\end{array}$} & Dirigente Z & Dirigente T \\
$\begin{array}{l}\text { Ligações Telefônicas e Chat (Sistema } \\
\text { Comunicação Instantânea) }\end{array}$ & $44 \%$ & $24 \%$ & $47 \%$ & $14 \%$ \\
Reuniões Agendadas & $5 \%$ & $23 \%$ & $13 \%$ & $48 \%$ \\
Reuniões Não Agendadas & $48 \%$ & $45 \%$ & $40 \%$ & $37 \%$ \\
Visita Interna Empresa & $3 \%$ & $9 \%$ & $1 \%$ & $0 \%$ \\
\hline
\end{tabular}

Nos dois casos, predominam os contatos pessoais com os subordinados e fornecedores (Tabela 6.40), cabendo a iniciativa para os dirigentes (65\% nos dois casos, conforme consta na Tabela 6.41). Os clientes são minoria nos participantes (1\%), exceto pelo percentual do tempo do Dirigente T (18\%), pelas características já comentadas anteriormente.

Tabela 6.40: Participantes Contato Pessoal Dirigentes Z e T

\begin{tabular}{lcccc}
\hline $\begin{array}{l}\text { Participantes: Percentual de Contatos / } \\
\text { Percentual do Tempo }\end{array}$ & \multicolumn{2}{c}{ Dirigente Z } & \multicolumn{2}{c}{ Dirigente T } \\
Subordinados & $69 \%$ & $66 \%$ & $48 \%$ & $57 \%$ \\
Clientes & $2 \%$ & $1 \%$ & $6 \%$ & $18 \%$ \\
Fornecedores & $25 \%$ & $22 \%$ & $28 \%$ & $12 \%$ \\
Outros & $4 \%$ & $12 \%$ & $19 \%$ & $12 \%$ \\
\hline
\end{tabular}

Tabela 6.41: Iniciativa Contato Pessoal Dirigentes Z e T

\begin{tabular}{lcc}
\hline \multicolumn{1}{c}{ Iniciativa: Percentual de Contatos } & Dirigente Z & Dirigente T \\
Própria & $65 \%$ & $65 \%$ \\
Planejada & $0 \%$ & $0 \%$ \\
Subordinados & $24 \%$ & $22 \%$ \\
Fornecedor & $10 \%$ & $2 \%$ \\
Cliente & $0 \%$ & $3 \%$ \\
Outras & $0 \%$ & $7 \%$ \\
\hline
\end{tabular}

São nos escritórios dos dirigentes onde se realizam a maioria absoluta dos contatos pessoais, em termos de quantidade ( $76 \%$ para $\mathrm{Z}$ e $70 \%$ para $\mathrm{T}$, conforme Tabela 6.42 ) e é nesse local que parte significativa do tempo é despendida para esse fim. 
Tabela 6.42: Lugar Contato Pess oal Dirigentes Z e T

\begin{tabular}{lcccc}
\hline \multicolumn{1}{c}{$\begin{array}{c}\text { Lugar: Percentual de Contatos / } \\
\quad \text { Percentual do Tempo }\end{array}$} & \multicolumn{2}{c}{ Dirigente Z } & \multicolumn{2}{c}{ Dirigente T } \\
Escritório Dirigente & $76 \%$ & $40 \%$ & $70 \%$ & $33 \%$ \\
Escritório Subordinado & $13 \%$ & $17 \%$ & $3 \%$ & $3 \%$ \\
Área Operacional & $2 \%$ & $5 \%$ & $1 \%$ & $2 \%$ \\
Fora da Empresa & $1 \%$ & $12 \%$ & $22 \%$ & $59 \%$ \\
Outro Lugar Empresa & $8 \%$ & $25 \%$ & $4 \%$ & $2 \%$ \\
\hline
\end{tabular}

Resumidamente, há um equilíbrio entre as diferenças e semelhanças na quantidade de características comparadas nos casos dos Dirigentes Z e T, conforme consta no Quadro 6.1.

\begin{tabular}{|l|c|c|}
\hline \multicolumn{1}{|c|}{$\begin{array}{c}\text { Características Comparadas } \\
\text { Dirigentes Z e T }\end{array}$} & Semelhanças & Diferenças \\
\hline Horas trabalhadas/dia & $\mathrm{X}$ & \\
\hline Correspondências processadas/dia & $\mathrm{X}$ & $\mathrm{X}$ \\
\hline $\mathrm{N}^{\mathbf{o}}$ atividades/dia & & $\mathrm{X}$ \\
\hline Duração atividades/dia & $\mathrm{X}$ \\
\hline Proporção atividades inferior 03 min. & $\mathrm{X}$ & \\
\hline Proporção atividades acima 60 min. & $\mathrm{X}$ & \\
\hline Meios de Contatos Pessoais & $\mathrm{X}$ & \\
\hline Participantes Contatos Pessoais & & $\mathrm{X}$ \\
\hline Lugar Contatos Pessoais & & $\mathrm{X}$ \\
\hline Atividades Mesa de Trabalho & & $\mathrm{X}$ \\
\hline Ligações Telefônicas & & $\mathrm{X}$ \\
\hline Reuniões Agendadas & $\mathrm{X}$ & \\
\hline Reuniões Não Agendadas & & $\mathrm{X}$ \\
\hline Visitas Internas e Externas & 8 & 8 \\
\hline Viagem Trabalho & & \\
\hline Intervalos & & \\
\hline \multicolumn{1}{|c|}{ Total } & & \\
\hline
\end{tabular}

Quadro 6.1: Características Comparadas Dirigentes Z e T

Fonte: Elaborado pelo Autor

De acordo com HALES (1999, 2001), ANDERSSON e FLORÉN (2009), as diferenças nas características das atividades dos administradores podem estar ligadas com alguns fatores contingenciais como a estrutura organizacional (grau de descentralização), o porte, o ambiente e tipo de indústria que as empresas operam.

Para os dois casos estudados, os Dirigentes $\mathrm{Z}$ e $\mathrm{T}$, as empresas atuam em setores (comércio e serviços) e ambientes de negócios (clientes, fornecedores e concorrência) 
completamente diferentes, eles têm estilos pessoais e responsabilidades nas empresas distintas, porém, ainda assim têm semelhanças nas características dos seus trabalhos. 


\section{ANÁliSE ENTRE TEORIA E PRÁtiCA NO TRABALHO DO ADMINISTRADOR DA PEQUENA EMPRESA}

Esse capítulo se propõe a analisar os resultados da pesquisa com os Dirigentes Z e T contrapondo-os com as teorias desenvolvidas sobre o trabalho do administrador por autores que contribuíram para o seu desenvolvimento, em especial, Mintzberg e Stewart.

A primeira seção contemplará os resultados do estudo de Mintzberg (1973) e de outros autores que se valeram do seu modelo aplicando-o inclusive para pequenas empresas, o que permitirá um diálogo mais direto com o objeto da pesquisa. Nesse sentido, pode-se observar que há, de maneira mais ampla, uma discreta predominância das diferenças sobre as semelhanças.

A segunda seção se propõe a interpretar as diferenças encontradas entre as características do trabalho dos Dirigentes $\mathrm{Z}$ e $\mathrm{T}$ aplicando a estrutura teórica do modelo das demandas, restrições e escolhas de Stewart (1982, 1998, 2008). Que fatores internos e externos, segundo o modelo teórico, justificariam escolhas diferentes para dirigentes submetidos a situações semelhantes?

Na terceira seção os dados da pesquisa foram interpretados para a identificação dos papéis executados de forma mais intensa pelos dirigentes, segundo o constructo da abordagem de papéis (MINTZBERG, 1973). É feita também uma análise das considerações do referido autor sobre o trabalho do administrador a partir dos estudos dos Dirigentes Z e T.

\subsection{Comparativo entre Dirigentes Estudados e Contribuições de Mintzberg e outros autores}

Mintzberg é um dos autores com uma das mais importantes contribuições para o estudo do trabalho do administrador, suas obras têm servido de referência para diversas pesquisas há mais de quarenta anos. Para Mintzberg (1973), são três os elementos básicos do trabalho do administrador: a interação com outras pessoas, o processamento da informação e a tomada de decisão. 
A análise comparativa entre os casos estudados de dirigentes de pequenas empresas e o estudo de Mintzberg (1973), realizado com executivos-chefes de grandes empresas, demonstra a existência tanto de semelhanças quanto de diferenças nos resultados.

Primeiramente, com base na comparação entre os estudos, pode-se observar que a duração da jornada diária de trabalho dos administradores é parecida, caracteristicamente breve (duração inferior a 09 minutos) e raramente se estendem acima de 60 minutos. Contudo, o número de atividades realizadas é muito diferente bem como a quantidade de correspondências processadas, conforme expresso na Tabela 7.1:

Tabela 7.1: Comparativo Categorias Mintzberg (1973) e Dirigentes Z e T (2011)

\begin{tabular}{lcc}
\hline \multicolumn{1}{c}{ Categorias } & Dirigentes Z e T & Mintzberg (1973) \\
Horas Trabalhadas/dia & $8: 25$ & $8: 08$ \\
Média Correspondências & 7 & 45 \\
processadas/dia & 89 & 22 \\
Atividades/dia & $0: 05$ & $0: 37$ \\
$\begin{array}{l}\text { Duração Média Atividades - em } \\
\text { Proporção de Atividades com Duração }\end{array}$ & $79 \%$ & $49 \%$ \\
Média inferior a 9 minutos & & $10 \%$ \\
Proporção de Atividades com Duração & $5 \%$ & \\
Média acima de 60 minutos & & \\
\hline
\end{tabular}

Com relação aos meios de contato, Tabela 7.2, as reuniões agendadas e não agendadas são as atividades que consomem o maior percentual de tempo dos administradores nos dois estudos e as visitas internas são pouco utilizadas em ambos os casos (menos de 10\%). Todavia, há uma enorme diferença na proporção do tempo gasto com reuniões agendadas entre eles: 34\% e 76\%, Dirigentes Z e T e estudo de Mintzberg, respectivamente.

Outro meio relevante, conforme Tabela 7.2, são os contatos usando recursos eletrônicos, importantes para todos (quantitativamente), porém, em uma proporção muito maior para os Dirigentes Z e T. Compreensível porque eles têm acesso, além da telefonia fixa, a móvel e a sistemas de comunicação instantânea, não disponíveis na época dos estudos de Mintzberg (1973), naturalmente.

\begin{tabular}{lcccc}
\multicolumn{2}{c}{ Tabela 7.2: Meios de Contato: Comparativo Mintzberg (1973) e Dirigentes Z e T (2011) } \\
\hline $\begin{array}{c}\text { Meios: Percentual de Contatos / } \\
\text { Percentual do Tempo }\end{array}$ & Dirigentes Z e T & Mintzberg (1973) \\
$\begin{array}{l}\text { Ligações Telefônicas e Chat (Sistema } \\
\text { Comunicação Instantânea) }\end{array}$ & $45 \%$ & $20 \%$ & $36 \%$ & $8 \%$ \\
Reuniões Agendadas & $6 \%$ & $34 \%$ & $29 \%$ & $76 \%$ \\
Reuniões Não Agendadas & $47 \%$ & $41 \%$ & $27 \%$ & $13 \%$ \\
Visita Interna Empresa & $2 \%$ & $5 \%$ & $8 \%$ & $3 \%$ \\
\hline
\end{tabular}


Os percentuais de contatos com os subordinados são muito próximos e altamente significativos (em torno de 64\%). Para os dirigentes do estudo de Mintzberg (1973), o tempo destinado para o contato com outras partes é bem maior que no caso dos Dirigentes $\mathrm{Z}$ e $\mathrm{T}$, $32 \%$ e $12 \%$, respectivamente, conforme Tabela 7.3:

Tabela 7.3: Participantes: Comparativo Mintzberg (1973) e Dirigentes Z e T (2011)

\begin{tabular}{lcccc}
\hline $\begin{array}{l}\text { Participantes: Percentual de Contatos / } \\
\text { Percentual do Tempo }\end{array}$ & \multicolumn{2}{c}{ Dirigentes Z e T } & \multicolumn{2}{c}{ Mintzberg (1973) } \\
Subordinados & $63 \%$ & $62 \%$ & $64 \%$ & $48 \%$ \\
Clientes & $3 \%$ & $9 \%$ & $2 \%$ & $3 \%$ \\
Fornecedores & $26 \%$ & $18 \%$ & $9 \%$ & $17 \%$ \\
Outros & $8 \%$ & $12 \%$ & $25 \%$ & $32 \%$ \\
\hline
\end{tabular}

Sobre o lugar onde os contatos pessoais acontecem, em termos de percentual de contatos e de tempo, os resultados dos dois estudos são extremamente parecidos; eles ocorrem, principalmente, nos seus próprios escritórios e fora da empresa (Tabela 7.4):

Tabela 7.4: Lugar - Comparativo Mintzberg (1973) e Dirigentes Z e T (2011)

\begin{tabular}{lcccc}
\hline $\begin{array}{c}\text { Lugar: Percentual de Contatos I } \\
\text { Percentual do Tempo }\end{array}$ & \multicolumn{2}{c}{ Dirigentes Z e T } & \multicolumn{2}{c}{ Mintzberg (1973) } \\
Escritório Dirigente & $75 \%$ & $37 \%$ & $75 \%$ & $39 \%$ \\
Escritório Subordinado & $11 \%$ & $10 \%$ & $10 \%$ & $8 \%$ \\
Área Operacional & $2 \%$ & $4 \%$ & $3 \%$ & $1 \%$ \\
Fora da Empresa & $5 \%$ & $35 \%$ & $8 \%$ & $38 \%$ \\
Outro Lugar Empresa & $7 \%$ & $14 \%$ & $3 \%$ & $14 \%$ \\
\hline
\end{tabular}

Os dirigentes comparados gastam proporções de tempo razoavelmente parecidas nas suas mesas de trabalho e nas ligações telefônicas, porém, com perfis muito diferentes entre si nos aspectos quantitativos (número de sessões e ligações) e na duração das mesmas, conforme apresentado nas Tabelas 7.5 e 7.6 :

Tabela 7.5: Mesa de Trabalho: Comparativo Mintzberg (1973) e Dirigentes Z e T (2011)

\section{Mesa de Trabalho}

Número de Sessões/dia

Duração Média - em Minutos

Proporção do Tempo

Dirigentes Z e T Mintzberg (1973)

26

0:02

$0: 15$

$15 \%$
$22 \%$

Tabela 7.6: Ligações Telefônicas: Comparativo Mintzberg (1973) e Dirigentes Z e T (2011)

\begin{tabular}{lcc}
\hline \multicolumn{1}{c}{ Ligações Telefônicas } & Dirigentes Z e T & Mintzberg (1973) \\
Número de Ligações/dia & 22 & 5 \\
Duração Média - em Minutos & $0: 02$ & $0: 06$ \\
Proporção do Tempo & $10 \%$ & $6 \%$ \\
\hline
\end{tabular}


A única semelhança entre as reuniões agendadas está na sua quantidade já que a duração e a proporção do tempo entre os dois estudos são completamente diferentes. Por exemplo, enquanto no estudo de Mintzberg (1973) a duração média está além de uma hora e absorvem 59\% do tempo dos contatos pessoais, para os dirigentes Z e T, são de 25 minutos e consomem $17 \%$ do seu tempo (Tabela 7.7).

\begin{tabular}{lcc}
\multicolumn{3}{c}{ Tabela 7.7: Reuniões Agendadas: Comparativo Mintzberg (1973) e Dirigentes Z e T (2011) } \\
\hline \multicolumn{1}{c}{ Reuniões Agendadas } & Dirigentes Ze T & Mintzberg (1973) \\
Número de Reuniões/dia & 4 & 4 \\
Duração Média - em Minutos & $0: 25$ & $1: 08$ \\
Proporção do Tempo & $17 \%$ & $59 \%$ \\
\hline
\end{tabular}

Já as reuniões não agendadas, conforme Tabela 7.8, têm um perfil muito diferente em quantidade, duração e proporção de tempo entre os estudos. Por exemplo, para os Dirigentes $\mathrm{Z}$ e $\mathrm{T}$ elas representam $35 \%$ do seu tempo nos contatos pessoais contra apenas $10 \%$ no estudo de Mintzberg (1973).

Tabela 7.8: Reuniões Não Agendadas: Comparativo Mintzberg (1973) e Dirigentes Z e T (2011)

\begin{tabular}{lcc}
\hline \multicolumn{1}{c}{ Reuniões Não Agendadas } & Dirigentes Z e T & Mintzberg (1973) \\
Número de Reuniões/dia & 26 & 4 \\
Duração Média - em Minutos & $0: 04$ & $0: 12$ \\
Proporção do Tempo & $35 \%$ & $10 \%$ \\
\hline
\end{tabular}

As visitas internas nas empresas não fazem parte da rotina dos dirigentes dos dois estudos. São realizadas, em média, uma por dia e representam apenas 3\% do seu tempo nos contatos pessoais, diferindo entre si somente na sua duração média, conforme detalhado na Tabela 7.9:

Tabela 7.9: Visita Interna: Comparativo Mintzberg (1973) e Dirigentes Z e T (2011)

\begin{tabular}{lcc}
\hline \multicolumn{1}{c}{ Visita Interna Empresa } & Dirigentes Z e T & Mintzberg (1973) \\
Número de Visitas/dia & 1 & 1 \\
Duração Média - em Minutos & $0: 05$ & $0: 11$ \\
Proporção do Tempo & $3 \%$ & $3 \%$ \\
\hline
\end{tabular}

O Quadro 7.1 apresenta um resumo comparativo entre os dois estudos e permite observar que, do ponto de vista da quantidade de características analisadas, há uma discreta predominância das diferenças sobre as semelhanças, a saber: 


\begin{tabular}{|l|c|c|}
\hline \multicolumn{1}{|c|}{$\begin{array}{c}\text { Características Comparadas: } \\
\text { Dirigentes Z e T (2011) e Mintzberg (1973) }\end{array}$} & Semelhanças & Diferenças \\
\hline Horas trabalhadas/dia & $\mathrm{X}$ & \\
\hline Correspondências processadas/dia & & $\mathrm{X}$ \\
\hline $\mathrm{N}^{\circ}$ atividades/dia & & $\mathrm{X}$ \\
\hline Duração atividades/dia & & $\mathrm{X}$ \\
\hline Proporção atividades inferior 09 min. & $\mathrm{X}$ & \\
\hline Proporção atividades acima 60 min. & $\mathrm{X}$ & \\
\hline Meios de Contatos Pessoais & $\mathrm{X}$ & \\
\hline Participantes Contatos Pessoais & $\mathrm{X}$ & \\
\hline Lugar Contatos Pessoais & & $\mathrm{X}$ \\
\hline Atividades Mesa de Trabalho & & $\mathrm{X}$ \\
\hline Ligações Telefônicas & & $\mathrm{X}$ \\
\hline Reuniões Agendadas & $\mathrm{X}$ & \\
\hline Reuniões Não Agendadas & 6 & 8 \\
\hline Visitas Internas & & \\
\hline \multicolumn{1}{|c|}{ Total } & & \\
\hline
\end{tabular}

Quadro 7.1: Resumo Comparativo entre estudos Dirigentes Z e T e Mintzberg (1973)

Fonte: Elaborado pelo Autor

A análise e interpretação dos dados coletados na pesquisa de campo com os Dirigentes $\mathrm{Z}$ e $\mathrm{T}$ permite visualizar o alinhamento existente com algumas das principais características sobre a natureza do trabalho do administrador apontadas por MINTZBERG (1973, 2010), HALES (1999, 2001), KOTTER (1982) e STEWART (2008), tais como:

- A comunicação é uma característica importante e ocorre, normalmente, de forma direta e informal, com alto nível de interação verbal e frequentemente face a face, em detrimento da escrita;

- Há grande quantidade de atividades desenvolvidas e executadas de forma variada, breve e fragmentada;

- Os dirigentes, raramente, estão sozinhos, mudando com freqüência sua atenção nos assuntos e interlocutores;

- Não parecem seguir um planejamento formal;

- A percepção do uso do tempo é relativa, acreditando que gastam mais tempo com algumas atividades do que com outras; 
- A dedicação de considerável proporção do tempo e esforço com atividades não-gerenciais como assistência em trabalhos de caráter técnico; e

- Nem sempre têm o controle dos seus próprios compromissos, frequentemente determinados por outros.

Outro aspecto a ser destacado, a partir das observações dos casos estudados com os dirigentes das pequenas empresas, é a forte presença do relacionamento baseado na confiança interpessoal, sempre próximo dos seus funcionários, enfatizando a informalidade com efeitos sobre as atividades funcionais, obrigações, tarefas e responsabilidades (JULIEN, 1997; LEONE, 1999; D’ AMBOISE; MULDOWNEY, 1988; GIBB, 2000; GRAY; MABEY, 2005; HAUGH; McKEE, 2004; BEAVER; JENNINGS, 2000; ANDERSSON; FLORÉN, 2009).

Florén e Tell (2006), conforme já visto, realizaram vários estudos abordando o tema do trabalho do administrador, inclusive replicando o modelo de Mintzberg (1973). As principais conclusões de suas pesquisas são apresentadas no Quadro 7.2 paralelamente com os resultados dos Dirigentes Z e T:

\begin{tabular}{|l|c|c|}
\hline \multicolumn{1}{|c|}{ Características } & $\begin{array}{c}\text { Florén e Tell } \\
(\mathbf{2 0 0 6 )}\end{array}$ & $\begin{array}{c}\text { Dirigentes Z e T } \\
(\mathbf{2 0 1 1})\end{array}$ \\
\hline Proporção do Tempo no Escritório & $80 \%$ & $37 \%$ \\
\hline Proporção Tempo Mesa de Trabalho & $46 \%$ & $15 \%$ \\
\hline Proporção Tempo Reuniões Agendadas & $15 \%$ & $17 \%$ \\
\hline Proporção Tempo Reuniões Não Agendadas & $50 \%$ & $35 \%$ \\
\hline $\mathrm{N}^{\mathbf{o}}$ Reuniões Não Agendadas/dia & 22 & 26 \\
\hline $\mathrm{N}^{\mathbf{o}}$ Atividades/dia & 55 & 89 \\
\hline $\mathrm{N}^{\circ}$ Visitas Internas/dia & 5 & 1 \\
\hline $\mathrm{N}^{\circ}$ Atividades com duração inferior a 09 minutos & $78 \%$ & $79 \%$ \\
\hline Proporção do Tempo em Contatos Pessoais: & & \\
- Subordinados & $51 \%$ & $64 \%$ \\
- Clientes & $10 \%$ & $9 \%$ \\
- Fornecedores & $28 \%$ & $18 \%$ \\
\hline Proporção Contatos por Iniciativa Própria & $58 \%$ & $65 \%$ \\
\hline
\end{tabular}

Quadro 7.2: Resumo Comparativo entre estudos Florén e Tell (2006) e Dirigentes Z e T Fonte: Elaborado pelo Autor

A análise do Quadro 7.2 demonstra que, embora os estudos tenham sido feitos com dirigentes de perfis muito diferentes, há mais semelhanças do que diferenças nos resultados, especialmente, nas reuniões agendadas (proporção do tempo e quantidade), nas reuniões não agendadas, nas atividades mais breves (inferiores a 09 minutos) e nos contatos pessoais com iniciativa por parte dos dirigentes.

Resumindo todas as análises comparativas dessa seção - Mintzberg (1973), Hales (1999, 2001), Kotter (1982), Stewart (2008) e Florén e Tell (2006) - pode-se observar que há 
mais semelhanças, quantitativas e qualitativas, do que diferenças entre os resultados da pesquisa com os Dirigentes $\mathrm{Z}$ e $\mathrm{T}$ e os estudos que se propuseram a entender a natureza do trabalho do administrador.

\subsection{Comparativo entre Dirigentes Estudados e Contribuição de Stewart}

Durante a realização da pesquisa pode-se observar que os dirigentes $\mathrm{Z}$ e $\mathrm{T}$ eram submetidos a responsabilidades de gestão semelhantes e, mesmo sob circunstâncias relativamente similares, os resultados pareciam ser diferentes.

Os dados coletados revelaram que características importantes dos seus trabalhos eram distintas, conforme visto no resumo comparativo apresentado no Quadro 6.1:

- Quantidade e duração das atividades diárias;

- Atividades executadas na mesa de trabalho;

- Meios de contato pessoal: ligações telefônicas e reuniões (agendadas ou não); e

- Viagem de trabalho.

Assim, o que poderia explicar esse fenômeno? Como interpretar essas diferenças?

Para responder essas perguntas, será aplicada a estrutura teórica do modelo das Demandas, Restrições e Escolhas desenvolvido por Stewart (1982, 2008), conforme constructo detalhado no Protocolo de Pesquisa (Apêndice C).

As Demandas formam a parte do núcleo central do trabalho do administrador (STEWART, 1982; HAMPTON, 1990) e, no caso dos dirigentes de pequenas empresas estudados, pode-se observar, em conformidade com as afirmações de Hales (1999, 2002), que são atividades cotidianas relacionadas à:

- Gestão de informações - oferta e recebimento de grande volume diário de informações vindas, na sua maioria, diretamente de subordinados e fornecedores;

- Monitoração e manutenção das pessoas e dos processos de trabalho - verificação das rotinas visando cumprimento de normas e prazos, ainda que informais; organização e alocação dos recursos humanos, financeiros e materiais para tarefas e atividades; 
- Busca de novas oportunidades de negócios - identificação, levantamento de informações, análise das alternativas e negociação com clientes, fornecedores e outras partes interessadas; e

- Execução de atividades não-gerenciais com trabalhos de caráter técnico operacional condução de processos de compras de mercadorias e insumos; contratação de subordinados; gestão operacional dos recursos financeiros.

As Restrições (STEWART, 1982; HAMPTON, 1990) são fatores, internos ou externos, tangíveis ou não, que limitam o trabalho do administrador. No caso dos dirigentes estudados, foram observadas restrições de natureza:

- Gerencial - legal, financeira, tecnológica e mercadológica;

- Organizacional - estrutura, processos e sistemas de gestão e informação; e

- Relacional - clientes, subordinados e fornecedores.

Segundo Stewart (1982) e Hampton (1990), as Escolhas são oportunidades que o administrador tem para agir diferentemente dos demais, enfatizando certos elementos que compõem seu trabalho, selecionando tarefas para executar pessoalmente ou delegando e compartilhando outras.

Esses aspectos pessoais puderam ser observados nos dois casos estudados ficando evidente muitas vezes a preferência dos dirigentes como determinante de suas escolhas.

Em certas circunstâncias, assumiam para si a responsabilidade pela execução de tarefas por entenderem que elas eram de importância estratégica para suas empresas. Por exemplo, a negociação direta com clientes e fornecedores ou a seleção de subordinados para espaços ocupacionais considerados críticos.

Já algumas características distintas nos trabalhos dos Dirigentes $\mathrm{Z}$ e $\mathrm{T}$ - o que faziam (atividades), quanto faziam (número de sessões), como faziam (duração) e com quem e como se relacionavam (contatos pessoais e meios utilizados) - eram fruto de suas escolhas e podem ser analisadas baseadas em aspectos internos e externos (STEWART 1982, 1998, 2008; HAMPTON, 1990):

- Porte da empresa, funções executadas, tipo de negócio, pessoas envolvidas, grau de experiência no cargo; 
- Passividade ou dinamismo diante das restrições, crenças pessoais, medos ou falta de conhecimento e habilidade técnica; e

- Circunstancias em que os eventos acontecem, expectativas das pessoais próximas e tempo de experiência na função.

Para uma mesma atividade que implicava um contato pessoal - a negociação de compra e venda com fornecedor ou cliente - os dois dirigentes conduziam o assunto de forma bastante distinta. Um preferiu o uso do telefone e o envio de e-mail; o outro escolheu o contato pessoal direto, implicando em reuniões externas e viagens não programadas.

Em grande parte, o tipo de negócio, as pessoas envolvidas, as crenças pessoais e as expectativas das pessoas próximas podem permitir a compreensão do motivo das diferenças nas escolhas nesse exemplo.

Em outra situação comum para os dois dirigentes - a execução de atividades diárias na mesa de trabalho - as escolhas foram novamente diferentes. Enquanto um permanecia na sua mesa de trabalho disciplinado seguindo um cronograma próprio que o levava a executar muitas atividades breves, diversificadas e fragmentadas, o outro dirigente optava por delegar o máximo possível as tarefas. Mantinha para si apenas aquelas que exigiam tempo de análise e elaboração estratégica, de forma a dedicar o tempo absolutamente necessário, de preferência o menor possível, na sua mesa de trabalho. Na sua visão, o importante era buscar a ação onde estivesse ocorrendo, no seu entendimento, fora do seu escritório e mesa de trabalho.

Nesse segundo caso, fatores como as funções executadas e o perfil mais dinâmico e estratégico de um dos dirigentes, podem justificar suas escolhas que provocaram diferenças nas características do seu trabalho.

\subsection{Interpretação dos Dados}

$\mathrm{O}$ conjunto das atividades desempenhadas pelos Dirigentes $\mathrm{Z}$ e $\mathrm{T}$ permitiu operacionalizar o conceito do modelo da abordagem dos papéis de Mintzberg (1973), conforme constructo no Apêndice $\mathrm{C}$, e interpretar o sentido que eles dão para o seu trabalho.

Com base na análise dos dados, ficou evidenciado que os dirigentes não desempenhavam todos os dez papéis plenamente e tampouco os executavam de forma homogênea; havia uma variação de acordo com o tipo de função e ocasião e, especialmente, 
prevaleciam os papéis relacionados aos interesses pessoais. Aspectos que Mintzberg (1973) já havia identificado em seus estudos.

O Dirigente Z, por exemplo, destacava-se por orientar pessoalmente seus subordinados na execução das tarefas e exercitar sua autoridade perante eles, características identificadas com o papel de Líder. Era marcante a maneira ágil e informal como recebia e repassava as informações e monitorava operações internas, atuando assim, como Monitor. Por fim, agia com desenvoltura na definição de prioridades e no exercício do controle das operações por meio da centralização das decisões; genuinamente, um Alocador de Recursos, de acordo com a teoria de Mintzberg (1973).

Por sua vez, o Dirigente T cumpria com desenvoltura e competência os papéis de Representante, ao assumir para si os deveres de caráter cerimonial e tratar assuntos específicos da alta gestão (como reuniões com clientes para tratar de assuntos institucionais da empresa); de Porta-voz, transmitindo informações para agentes externos como representantes sindicais e do poder público; e, talvez o mais representativo de todos, o papel de Negociador, estando à frente todas às vezes que avaliou ser necessário, representando os interesses da empresa como porta-voz e alocador de recursos (MINTZBERG, 1973).

Mintzberg (1973) também afirma que o pequeno porte da empresa exerce influência na natureza do trabalho do administrador porque este dá especial atenção aos problemas operacionais, é inclinado a executar ele próprio algumas tarefas de seus subordinados, mesmo que não-gerenciais, e se vê como empreendedor.

Em linhas gerais, foi possível verificar que a afirmação de Mintzberg (1973) correspondia a realidade dos dirigentes pesquisados visto que era comum desempenharem pessoalmente tarefas operacionais (compras e conferência de produtos e insumos, por exemplo), assumirem diretamente a função de subordinados e se verem como empreendedores, envolvidos em diferentes demandas do negócio (identificação de oportunidades, projetos de melhoria e ações em várias frentes no comercial, finanças e logística).

De outra forma, analisando as proposições de Mintzberg (1973) sobre as características do trabalho do administrador, alguns pontos não foram ratificados pela pesquisa. Por exemplo, não foi possível verificar a aparente preferência dos dirigentes pela brevidade e interrupção de suas atividades. 
Ainda que eles próprios tomassem a iniciativa da interrupção na maior parte das vezes, a fragmentação do trabalho não parecia ser algo que lhes causasse satisfação particular. Pelo contrário, algumas vezes se sentiam "improdutivos", considerando-se falhos, como um "erro" a ser corrigido pelo desgaste emocional e físico que sentiam.

Nos dois casos, a importância das correspondências (contato escrito) no trabalho dos dirigentes, entenda-se e-mails enviados e recebidos, era menor do que o relatado no estudo de Mintzberg (1973). As hipóteses sugeridas para explicar esse fato são a maior disponibilidade de outros recursos tecnológicos em relação a 40 anos atrás (telefonia em especial), o perfil dos contatos internos (subordinados) e externos (fornecedores e clientes) e a preferência dos dirigentes pelo contato verbal, mais ágil, simples e pessoal que o escrito. Por exemplo, para cada três ligações telefônicas (recebida ou realizada) havia um e-mail enviado ou recebido.

Outro ponto a observar e que difere dos resultados do trabalho de Mintzberg (1973) é a importância das reuniões agendadas (76\% da proporção do tempo, segundo o autor). Elas tinham um peso importante para os dirigentes (34\%), mas não consumiam a maior parcela do seu tempo dentre os meios de contato pessoal, cabendo as reuniões não agendadas essa primazia $(41 \%)$.

Por fim, vale destacar que os dirigentes, a exemplo do que Mintzberg (1973) afirmou, parecem ter sim algum controle efetivo sobre suas ações. Ainda que estejam muito próximos de onde ela ocorre, o que poderia sugerir uma exposição maior e reféns das iniciativas e agendas de outros (clientes, fornecedores e subordinados), na prática, não é exatamente assim que parece acontecer.

Como precisam distribuir seu "disputado" tempo para tantas atividades, os dirigentes parecem fazer uma "triagem" nos assuntos, procurando resolvê-los com base no interesse de curto prazo, geralmente. Preferem os mais simples e de solução rápida, delegando quando possível, aqueles que possam exigir algum conhecimento específico ou são imprecisos quanto aos resultados práticos. Dessa forma, procuram reservar parcela de seu tempo para temas tidos como estratégicos e críticos para o sucesso dos seus negócios. Ou seja, parecem estar no controle da situação a maior parte do tempo, fazendo aquilo que julgam realmente útil. 


\section{CONSIDERAÇÕES FINAIS}

Ao final da pesquisa foi possível observar se as abordagens do trabalho do administrador têm eficácia na explicação da natureza do trabalho dos dirigentes da pequena empresa. Isso porque, em linhas gerais, comparando-se os resultados dos casos estudados - o que, como, quanto, onde e com quem os dirigentes das pequenas empresas executam suas atividades - com as teorizações selecionadas para trabalho (MINTZBERG, 1973; HALES, 1999, 2001; KOTTER, 1982; STEWART, 2008; FLOREN; TELL, 2006) foi possível concluir que há mais semelhanças nelas do que propriamente diferenças.

\subsection{Sobre o Objetivo da Pesquisa}

De todos os aspectos pesquisados, identificados e analisados sobre as características do trabalho dos dirigentes da pequena empresa e as coerências com as teorizações existentes, talvez as características mais significativas possam ser resumidas nos seguintes pontos:

- A comunicação pessoal como algo relevante e informal, com alto nível de interação verbal e frequentemente face a face, em detrimento da escrita, e mudança freqüente nos assuntos;

- Grande volume de atividades desenvolvidas e executadas de forma variada, breve e fragmentada;

- Alto nível de interação com variedade de interlocutores;

- Dedicação de considerável proporção do tempo e esforço com atividades não-gerenciais;

- Contatos pessoais involuntários, porém, frequentemente determinados por eles próprios; e

- O controle do seu próprio tempo e agenda.

Contudo, essa visão deve ser entendida com a devida cautela, natural toda generalização. Por exemplo, comparativamente ao trabalho de Mintzberg (1973), foi possível identificar uma maior predominância das diferenças do que semelhanças. Por sua vez, no trabalho de Florén e Tell (2006) são mais evidentes as semelhanças que as diferenças.

O Quadro 8.1 coloca lado a lado os três trabalhos possibilitando verificar que há características comuns na sua relevância, porém, com intervalos de valores significativamente diferentes. Por exemplo: relação entre reuniões agendadas e não agendadas; número de 
atividades com duração inferior a 09 minutos; proporção do tempo em contatos pessoais com subordinados, clientes e fornecedores.

\begin{tabular}{|c|c|c|c|}
\hline Características & $\begin{array}{c}\text { Mintzberg } \\
\text { (1973) }\end{array}$ & $\begin{array}{l}\text { Florén e Tell } \\
\quad(2006)\end{array}$ & $\begin{array}{c}\text { Dirigentes } \\
\text { Z e T } \\
\text { (2011) }\end{array}$ \\
\hline Proporção do Tempo no Escritório & $39 \%$ & $80 \%$ & $37 \%$ \\
\hline Proporção Tempo Mesa de Trabalho & $22 \%$ & $46 \%$ & $15 \%$ \\
\hline Proporção Tempo Reuniões Agendadas & $76 \%$ & $15 \%$ & $17 \%$ \\
\hline $\begin{array}{l}\text { Proporção Tempo Reuniões Não } \\
\text { Agendadas }\end{array}$ & $13 \%$ & $50 \%$ & $35 \%$ \\
\hline $\mathrm{N}^{\circ}$ Reuniões Não Agendadas/dia & 4 & 22 & 26 \\
\hline $\mathrm{N}^{\circ}$ Atividades/dia & 22 & 55 & 89 \\
\hline $\mathrm{N}^{\circ}$ Visitas Internas/dia & 1 & 5 & 1 \\
\hline $\begin{array}{l}\mathrm{N}^{\mathbf{o}} \text { Atividades com duração inferior a } 09 \\
\text { minutos }\end{array}$ & $49 \%$ & $78 \%$ & $79 \%$ \\
\hline $\begin{array}{l}\text { Proporção do Tempo em Contatos } \\
\text { Pessoais: } \\
\text { - Subordinados } \\
\text { - Clientes } \\
\text { - Fornecedores }\end{array}$ & $\begin{array}{c}48 \% \\
3 \% \\
17 \% \\
\end{array}$ & $\begin{array}{l}51 \% \\
10 \% \\
28 \% \\
\end{array}$ & $\begin{array}{c}64 \% \\
9 \% \\
18 \% \\
\end{array}$ \\
\hline $\begin{array}{l}\text { Proporção Contatos por Iniciativa } \\
\text { Própria }\end{array}$ & $32 \%$ & $58 \%$ & $65 \%$ \\
\hline
\end{tabular}

Quadro 8.1: Comparativo estudos Mintzberg, Florén e Tell e Dirigentes Z e T

Fonte: Elaborado pelo Autor

\subsection{Contribuição da Pesquisa}

Além de contribuir para os estudos organizacionais que visam o desenvolvimento de uma teoria administrativa para a pequena empresa, espera-se que essa pesquisa sirva de inspiração para seus dirigentes conhecerem mais sobre a teoria a respeito do seu trabalho.

Nesse sentido, sugere-se fazer uma devolutiva com os dirigentes pesquisados apresentando e discutindo os resultados individuais e consolidados do estudo. Por exemplo, número e meios de contatos, duração, local e iniciativa. Seria uma forma para aproximá-los das atividades acadêmicas e de outras pesquisas sobre o tema, inspirando-os ao autoconhecimento e a busca de informações a respeito dos projetos de consultoria visando à melhoria da competitividade dos seus negócios.

\subsection{Limitações da Pesquisa}

Embora o estudo de caso seja um valioso instrumento para refinamento da teoria, seu uso está sujeito a uma série de limitações sobre a capacidade de aplicação dos resultados (HAUGH; McKEE, 2004), grau de subjetividade e elevados custos de tempo e dinheiro 
(STAKE, 1995). Assim, a pesquisa tem algumas limitações que precisam ser evidenciadas com o objetivo de permitir ao leitor um entendimento e avaliação mais crítica e isenta dos seus resultados.

Primeiramente, é importante registrar que os critérios de escolha dos dirigentes e empresas pesquisados devem ser considerados na análise dos resultados. Por estarem sediados no Estado de São Paulo, naturalmente, refletem as características peculiares da região como formação cultural, grau de desenvolvimento, competitividade mercadológica, perfil de consumo e renda e indicadores, diferenciados em relação à média nacional.

Outro aspecto que deve ser destacado é a proximidade e o conhecimento do pesquisador a respeito dos dirigentes e das empresas. A parte dos benefícios já destacados, essa é uma condição incomum e dificilmente isolada por completo, ainda que algumas medidas tenham sido tomadas para minimizar seus possíveis efeitos na pesquisa.

Além disso, para chegar ao mesmo nível de informação e conhecimento, não é improvável que outro pesquisador necessite de um investimento de tempo prévio expressivo no levantamento de informações preliminares. Mintzberg (1973), para a execução da sua pesquisa, declarou ter dedicado um mês nessa atividade preparatória, isso contando com a providencial ajuda das secretárias dos dirigentes no registro das agendas de trabalho.

Há uma limitação na pesquisa que consiste em avaliar em que grau o estilo pessoal dos dirigentes influencia a forma como conduzem suas atividades e poderia ter interferido nos resultados? Em especial, na interpretação dos papéis desempenhados (MINTZBERG, 1973), ainda que o conceito tenha sido operacionalizado a partir do constructo teórico, a carga de subjetivismo no entendimento é bastante significativa. É absolutamente possível que dois pesquisadores tenham interpretações diferentes para eventos iguais.

Durante a coleta de dados propriamente, foi difícil acompanhar em tempo real as informações trafegadas por meio dos instrumentos de comunicação instantânea, no caso chat. $\mathrm{Na}$ realidade, houve uma dependência total do gestor permitindo a leitura e o registro dos dados de interesse, não fosse dessa forma, as limitações seriam maiores ainda. Levando-se em consideração o uso cada vez mais presente desses recursos, adicionando também os serviços de mensagens tipo "torpedos" telefônico, as dificuldades poderão ser ampliadas em estudos futuros.

Um fator limitante para operacionalizar pesquisas com as mesmas características é a necessidade de recursos financeiros suficientes para os gastos inerentes ao período de coleta 
de dados de campo, por uma semana para cada dirigente, com deslocamentos, hospedagem e alimentação.

Finalmente, talvez a mais importante limitação esteja na total dependência para a realização e o sucesso da pesquisa que a presença do dirigente tem; ele não pode adoecer, se afastar por mais de um dia, desistir ou se desmotivar. Mais do que isso, ele precisa estar disposto e verdadeiramente interessado em colaborar, caso contrário, as dificuldades serão enormes, podendo inviabilizar o trabalho. Ou seja, sem o dirigente motivado pelos mesmos objetivos, como se estivesse de "corpo e alma" não haveria pesquisa.

\subsection{Sugestões e Trabalhos Futuros}

A primeira sugestão para trabalhos futuros é que um dos casos, pelo menos, observasse o dirigente em outros contextos e situações variadas. Por exemplo, investigar uma empresa do setor industrial; ou uma dirigente; ou uma empresa nascente em seu estágio inicial do ciclo de vida organizacional; ou uma empresa localizada fora do Estado de São Paulo; ou que tenha vínculos institucionais como as empresas incubadas; ou a vocação de negócio típica do perfil inovador.

Também poderia ser contributivo para o desenvolvimento de uma teoria brasileira sobre o trabalho do dirigente da pequena empresa que novas pesquisas com o mesmo perfil fossem realizadas com estudos transversais, permitindo uma avaliação dos fenômenos e resultados no decorrer do tempo. Um trabalho inspirado naquilo que Mintzberg (2010) fez com seu modelo da abordagem dos papéis, quando o atualizou com base em dados colhidos 20 anos depois e reconheceu algumas limitações e a necessidade de ajustes.

Por fim, algumas sugestões de melhoria visando enriquecer a coleta e análise dos dados pelo pesquisador, por exemplo, o registro de imagens dos locais de trabalho, instalações, equipamentos da empresa e situações ilustrativas do cotidiano. Também, registrar a imagem e o áudio das entrevistas estruturadas com os dirigentes, permitindo um histórico detalhado dos dados coletados, formando uma base de conhecimento multimídia sobre o tema. Naturalmente, desde que todas essas ações tivessem o consentimento informado dos dirigentes e seus subordinados. 


\section{REFERÊNCIAS}

ANDERSSON, S.; FLORÉN, H. (2008). Exploring managerial behavior in small international firms. Journal of Small Business and Development, v.15, n.1, p.31-50.

ANDERSSON, S.; FLORÉN, H. (2009). Exploring differences in the work of owner-managers in small international and non-international firms. In: COMPETITIVE PAPER PREPARED FOR 12th McGILL INTERNATIONAL ENTREPRENEURSHIP CONFERENCE. Hanken School of Economics, Vaasa, Finland. Sep., p.18-20.

APPLETON, J. V. (2002). Critiquing approaches to case study design for a constructivist inquiry. Qualitative Research Journal, v.2, n.2, p.80-97.

ARMAN, R. DELLVE, L. WIKSTROM, E. TORNSTROM, L. (2009). What health care managers do: applying Mintzberg's structured observation method. Journal of Nursing Management, v.17, p.718-729.

BARLEY, S.R. KUNDA, G. (2001). Bringing work back in. Organization Science, v.12, n.1, p.7695.

BEAVER, G. JENNINGS, P. (2000). Editorial overview: small business, entrepreneurship and enterprise development. Strategic Change, v.9, p.397-403.

BRITTEN, N. Entrevistas Qualitativas. In: POPE, C.; MAYS, N. (2009). Pesquisa qualitativa na atenção à saúde. 3. Ed. Porto Alegre: Artmed. Cap. 2, p.23-31.

CARLSON, S. (1951). Executive behavior. Reprinted with contributions by Henry Mintzberg and Rosemary Stewart. Studia oeconomiae Negotiorum 32. Uppsala.

CARROLL, S. J.; GILLEN, D. J. (1987). Are the classical management functions useful in describing managerial work? Academy of Management Review, v.12, n.1, p.38-51.

CRESWELL, J.W. (2007). Projeto de Pesquisa: métodos qualitativo, quantitativo e misto. 2.ed. Porto Alegre: Artmed.

D'AMBOISE, G.; MULDOWNEY, M. (1988). Management Theory for Small Business: Attempts and Requirement. Academy of Management Review, v.13, n.2, Apr.

DRUCKER, P.F. (1998). Prática da administração de empresas. 1.ed. São Paulo, Pioneira.

DUTRA, I, GUAGLIARDI, J.A. (1984). As micro e pequenas empresas: uma revisão da literatura de marketing e os critérios para caracterizá-las. Revista de Administração de Empresas, v.24, n.4, p.123-131, out/dez.

EASTERBY-SMITH, M.; THORPE, R.; LOWE, A. (1999). Pesquisa gerencial em administração: um guia para monografias, dissertações, pesquisas internas e trabalhos em consultoria. São Paulo: Pioneira.

EISENHARDT, K.M. (1989). Building theories from case study research. Academy of Management. The Academy of Management Review, v.14, n.4, Oct.

FAYOL, H. (1965). Administração industrial e geral. 6.ed. São Paulo: Atlas.

FLORÉN, H. (2006). Managerial work in small firms: summarizing what we know and sketching a research agenda. International Journal of Entrepreneurial Behavior \& Research, v.12, n.5, p. 272288. 
FLORÉN, H.; TELL, J. (2006). Managerial work in small firms - testing the robustness in

Mintzberg's propositions. CPDR on Innovation and Product Development, Sven Åke Hörte (ed.), p.123-139.

(2009). Managerial behavior in slow and fast growing small firms. Research on Technology, Innovation and Marketing Management, Sven Åke Hörte (ed.), p.109-123.

FULLER, T. (2000). Will small become beautiful? Futures, n.32, p.79-89.

(2003). Small business futures in society. Futures, n.35, p.297-304.

. (2003). If you wanted to know the future of small business what questions would you ask?

Futures, n.35, p.305-321.

GIBB, A. (2000). SME Policy, Academic Research and the Growth of Ignorance, Mythical Concepts, Myths, Assumptions, Rituals and Confusions. International Small Business Journal, v.18, p.13-35.

GOODWIN, D. (2009). Aspectos Éticos. In: POPE, C.; MAYS, N. Pesquisa qualitativa na atenção à saúde. 3.ed. Porto Alegre: Artmed, Cap.6, p.67-75.

GOTTSCHALK, P. (2002). The chief information officer: a study of managerial roles in Norway. PROCEEDING OF THE 35TH. HAWAII INTERNATIONAL CONFERENCE ON SYSTEM SCIENCES (HICSS-35-02).

GRAY, C.; MABEY, C. (2005). Management Development Key Differences between Small and Large Businesses in Europe. International Small Business Journal, v.23, n.5, p.467-485.

HALES, C. (1999). Why do Managers Do What They Do? Reconciling Evidence and Theory in Accounts of Managerial Work. British Journal of Management, v.10, p.335-350.

. (2001). Does It Matter What managers Do? Business Strategy Review, v.12, n. 2, p.50-58.

. (2002). "Bureaucracy-lite" and Continuities in Managerial Work. British Journal of Management, v. 13, p.51-66.

. (2005). Rooted in Supervision, Branching into Management: Continuity and Change in the Role of First-Line Managers. Journal of Management Studies, v.42, n.3.

HALES, C. TAMANGANI, Z. (1996). An investigation of the relationship between organizational structure, managerial role expectations and managers 'work activities. Journal of Management Studies, v.33, n.6.

HAMPTON, D.R. (1980). Administração contemporânea: teoria, práticas e casos. São Paulo: McGraw-Hill do Brasil. (1990). Administração: processos administrativos. São Paulo: Makron Books.

HAUGH, H. McKEE, L. (2004). The cultural paradigm of the smaller firm. Journal of Small Business Management, v.42, n.4, p.377-394.

HUANG, X. BROWN, A. (1999). An analysis and classifications of problems in small business. International Small Business Journal, v.18, n.73.

IBGE. As micro e pequenas empresas comerciais e de serviços no Brasil. (2003). Disponível em: <http://www.ibge.gov.br/home/estatistica/economia/microempresa/microempresa2001.pdf.>. Acesso em: 11 abr. 2010. 
IBGE. Demografia das empresas no Brasil. (2006). Disponível em: $<$ http://www.ibge.gov.br/home/estatistica/economia/demografiaempresa/2006/demoempresa2006. pdf >. Acesso em: 11 abr. 2010.

JACKSON, J.F.L. PETERSON, K.D. (2004). Executive Behavior: An Examination of Selected Studies for Three Decades of Administrative Work Across Organizational Settings, Industries, and Contexts. Journal of Leadership \& Organizational Studies, v.10, n.03.

JULIEN, P.A. (1997). Para uma definição das PME. In: Lês PME bilan et perspectives. 2.ed. Québec: econômica.

KONRAD, A.M. KASHLAK, R. YOSHIOKA, I. WARYSZAK, R. TOREN, N. (2001). What do managers like to do?: a five-country study. Group Organization Management, v. 26, n.401.

KOTTER, J.P. (1982). What effective general managers really do. Harvard Business Review, n.60, p.156-67.

KROECK, K.G. (2003). Rosemary Stewart on management: behavioral scribe, squire of theory, pragmatic scientist. The Leadership Quarterly, v.14, p.204-216.

LAITINEN, E.K. (2009). Importance of performance information in managerial work. Industrial Management \& Data Systems, v.109, n. 4, p.550-569.

LAMOND, D. (2003). Henry Mintzberg vs Henri Fayol: Of Lighthouses, Cubists and the Emperor's New Clothes. Journal of Applied Management and Entrepreneurship, v. 8, n. 4.

LEONE, N. M.C.P.G. (1991). A dimensão física das pequenas e médias empresas (P.M. E’S): à procura de um critério homogeneizador. Revista de Administração de Empresas, v.31, n.2, p.53-59, abr/jun.

(1999). As especificidades das pequenas e médias empresas. Revista de Administração, São Paulo, v. 34, n.2, p.91-94, abr./jun.

LOWE, K.B. (2003). Demands, Constraints, Choices and Discretion: an introduction to the work of Rosemary Stewart. The Leadership Quarterly, v.14, p.193-238.

LUTHANS, F.; ROSENKRATZ, S.A.; HENNESSEY, H.W. (1985). What do successful managers realy do? An observations study of managerial activities. v.21, n.3, p.255-270. In: Managerial work (history of management thought). Stewart, R. (Ed.). Aldershot: Ashgate Dartmouth, 1998.

MARTINKO, M.J; GARDNER, W.L. (1985). Beyond Structured Observation: Methodological Issues and New Directions. Academy of Management Review, v. 10. n. 4, p.676-695. In: Managerial work (history of management thought). Stewart, R. (Ed.). Aldershot: Ashgate Dartmouth, 1998.

MECH, T. (1997). The managerial roles of Chief Academic Officers. The Journal of Higher Education, v. 68, n. 3, p. 282-298.

MINTZBERG, H. (1970). Structured observation as method to study managerial work. The Journal of Management Studies. p. 209-226, Feb. In: Managerial work (history of management thought). Stewart, R. (Ed.). Aldershot: Ashgate Dartmouth, 1998.

. (1971). Managerial work: analysis from observation. Management Science. v. 18. n. 2. In: Managerial work (history of management thought). Stewart, R. (Ed.). Aldershot: Ashgate Dartmouth, 1998. 
(1986). O trabalho do executivo: o folclore e o fato. (São Paulo: Nova Cultural. (Coleção

Harvard de Administração, n. 3).

. (1994). Rounding out the manager's Job. Sloan Management Review, Fall.

$\overline{10 . \text { n. } 3 .}$

(1997). Managing on the edges. International Journal of Public Sector Management, v. p.140-147.

(1998). Covert leadership: Notes. Harvard Business Review, n.76, November/December,

(2010). Managing: desvendando o dia a dia da gestão. Porto Alegre: Bookman.

MOREIRA, H.; CALEFFE, L.G. (2006). Abordagens à pesquisa. In: Metodologia da pesquisa para o professor universitário. Rio de Janeiro: DP\&A. Cap.II, p.39-67.

NOORDEGRAAF, M.; STEWART, R. (2000). Managerial behavior research in private and public sectors: distinctiveness, disputes and directions. Journal of Management Studies, v.37, n.3.

O'GORMAN, C.; BOURKE, S.; MURRAY, J.A. (2005). The Nature of Managerial Work in Small Growth-Orientated Business. Small Business Economics, v.25, n.1, p.1-16.

OLIVEIRA, J. (2010). Estilos gerenciais do dirigente e estágios de desenvolvimento da pequena empresa: proposição de um modelo baseado nas funções e nos papéis do administrador e no setor metal-mecânico de Araraquara, Matão e São Carlos - SP. 289 p. Tese (Doutorado) - Escola de Engenharia de São Carlos, Universidade de São Paulo, São Carlos.

PERREN, L.; RAM, M. (2004). Case-study method in small business and entrepreneurial research: mapping the boundaries and perspectives. International Small Business Journal, v.22, n.83, p.83101.

POPE, C.; MAYS, N. (2009). Pesquisa qualitativa na atenção à saúde. 3.ed. Porto Alegre: Artmed.

POPE, C.; ZIEBLAND, S.; MAYS, N. (2009). Analisando dados qualitativos. In: Pesquisa qualitativa na atenção à saúde. 3.ed. Porto Alegre: Artmed. Cap.7, p.77-95.

REIJONEN, H. (2008). Understanding the small business owner: what they realy aim at and how this relates to firm performance. Management Research News, v.31. n.8, p.616-629.

SEBRAE. (2006). Onde estão as micro e pequenas empresas no Brasil. Observatório das MPEs SEBRAE-SP. Disponível em:

<http://www.sebraesp.com.br/sites/default/files/resultado_mpe_brasil.pdf.> Acesso em: 11 abr. 2010.

SNYDER, N.; GLUECK, W.F. (1980). How managers plan - the analysis of managers activities.

Long Range Planning, v.13, p.70-76, February.

SOUZA, M.C.A. F; MAZZALI, L. (2008). Conceito e espaço da pequena empresa na estrutura industrial: heterogeneidade e forma de inserção. Gestão e Produção, São Carlos, v.15, n.3, p.591-603, set-dez.

STAKE, R. E. (1995). The art of case study research. Sage Publications, Inc.

Case studies. (2003). In: DENZIN, N. K.; LINCOLN, Y. S. Strategies of qualitative inquiry. $2^{\text {nd }}$. Ed. Thousand Oaks: Sage Publishers. 
STEWART, R. (1979). To Understand the Manager's Job: Consider Demands, Constraints, Choices. Organizational Dynamics, v.4.

. (1982). A model for understanding managerial jobs and behavior. Academy of Management. The Academy of Management Review (pre-1986), v.7, p.7.

. (1998). Managerial Work - History of Management Thought. Aldershot, England.

. (2008). A Tougher World: Managerial Work and Behavior. In: Mapping the Management

Journey: practice, theory, and context. Oxford University Press, New York.

TENGBLAD, S. (2002). Time and space in managerial work. Scandinavian Journal of Management, v.18, p.543-565.

. (2003). Classic, but not seminal: revisiting the pioneering study of managerial work.

Scandinavian Journal of Management, v.19, p.85-101.

. (2006). Is there a 'New Managerial Work'? A Comparison with Henry Mintzberg's Classic

Study 30 Years Later. Journal of Management Studies, v.43, n.7.

TERENCE, A.C.F. (2009). Processo de criação de estratégias em pequenas empresas: elaboração de um mapa estratégico para empresas de base tecnológica do pólo de São Carlos/SP. 253 p. Tese (Doutorado) - Escola de Engenharia de São Carlos, Universidade de São Paulo, São Carlos.

TORRÈS, O.; JULIEN, P. (2005). Specificity and Denaturing of Small Business. International Small Business Journal, v.23, n.4, p.355-377.

TONELLI, M. J. (2005). À Beira de um Ataque de Nervos: Um Dia na Vida de Executivos em São Paulo. Revista GVpesquisa, São Paulo, v.1, p.24-37, dez.

TURATO, E.R. (2005). Métodos qualitativos e quantitativos na área da saúde: definições, diferenças e seus objetos de pesquisa. Revista de Saúde Pública, v.39, n.3, p.507-514.

VOSS, C.; TSIKRIKTSIS, N.; FROHLICH, M. (2002). Case research in operations management. International Journal of Operations \& Production Management, v.22. n.2. p.195-219.

WAHLGRÉN, A. STEWART, R. (2003). Owner-managers: freedoms and constraints. Strategic Change, v.12, p.21-29.

WHITLEY, R. (1989). On the nature of managerial tasks and skills: their distinguishing characteristics and organization. Journal of Management Studies, v.26, n.3, p.337-352, May. In: Managerial Work - History of Management Thought. Aldershot, England, 1998.

WILLMOTT, H. (1987). Studing managerial work: A critique and a proposal. Journal of Management Studies, v.24, n.3, p.249-270, May. In: Managerial Work - History of Management Thought. Aldershot, England, 1998.

WREN, D. A. (2007). Ideias de Administração: o pensamento moderno. São Paulo: Editora Ática. YIN, R.K. (2005). Estudo de caso: planejamento e métodos. 3.ed. Porto Alegre: Bookman. 
APÊNDICE A - CARACTERIZAÇÃO EMPRESA E DIRIGENTE

\begin{tabular}{|c|c|c|c|}
\hline \multicolumn{4}{|c|}{ Perfil Empresa } \\
\hline \multicolumn{4}{|l|}{ Empresa (Razão Social): } \\
\hline Ano de fundação da empresa: & \multicolumn{3}{|c|}{ Telefone comercial: } \\
\hline \multicolumn{4}{|l|}{ Endereço: } \\
\hline Setor: & \multicolumn{2}{|c|}{ Atividade principal da empresa: } & $\begin{array}{l}\text { Número total de } \\
\text { empregados: }\end{array}$ \\
\hline Empresa tem filiais? & \multicolumn{3}{|c|}{ Principais serviços ou produtos oferecidos: } \\
\hline \multicolumn{4}{|l|}{ Perfil principais clientes: } \\
\hline \multicolumn{4}{|c|}{ Perfil Dirigente } \\
\hline \multicolumn{2}{|l|}{ Nome do dirigente: } & Data nascimento: & Sexo: \\
\hline \multicolumn{2}{|l|}{ Proprietário da empresa? } & \multicolumn{2}{|c|}{ Tem sócios? Trabalham na empresa? } \\
\hline \multicolumn{2}{|l|}{ Quanto tempo dirige a empresa: } & \multicolumn{2}{|c|}{ Nível de escolaridade: } \\
\hline \multicolumn{2}{|l|}{ Cargo na empresa: } & \multicolumn{2}{|c|}{ Outros negócios atuais: } \\
\hline \multicolumn{2}{|c|}{ Quantas pessoas se reportam diretamente? } & \multicolumn{2}{|c|}{ Outros negócios anteriores: } \\
\hline
\end{tabular}



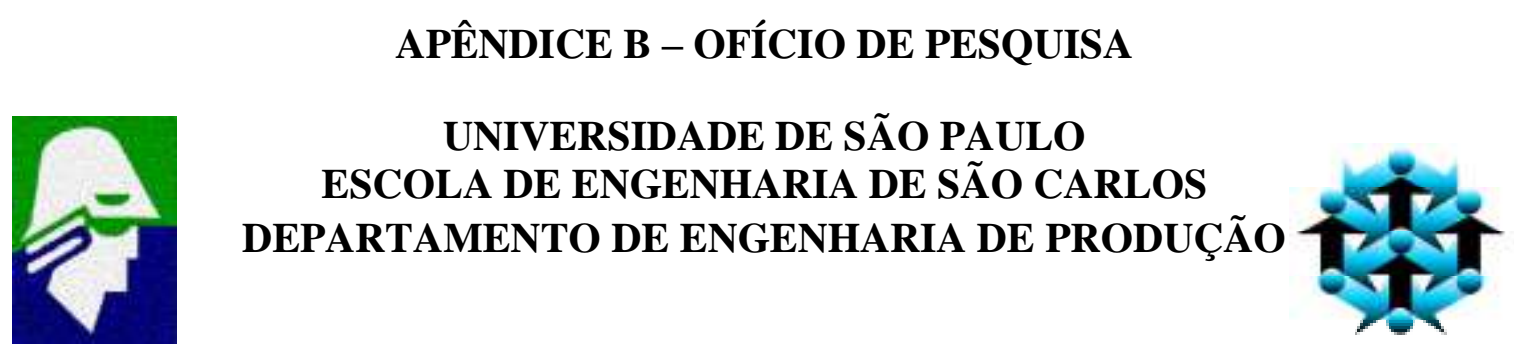

Prezado (a) Senhor (a),

Estamos realizando uma pesquisa com o objetivo de estudar o trabalho do administrador de empresas.

Para atingir nossos objetivos, realizaremos a pesquisa na sua empresa durante o período de de de 20__ quando acompanharemos suas atividades diárias, faremos observações de eventos, tomaremos nota, pediremos para ler documentos internos e teremos reuniões para validação dos dados coletados.

Não será solicitada informação sigilosa e a tabulação e análise dos dados será feita de forma a manter a confidencialidade das informações e anonimato, caso seja solicitado, dos participantes. Pois, a finalidade é compreender como ocorre o trabalho do dirigente na sua empresa.

Certos de contarmos com sua participação, antecipadamente agradecemos.

São Carlos, de 20

Edmundo Escrivão Filho

Professor Associado

Departamento de Engenharia de Produção - EESC/USP edesfi@sc.usp.br

Sérgio R. Gromik

Mestrando em Engenharia de Produção - EESC/USP gromik@ideiasesolucoes.com.br

Concordo com os termos e aceito participar da pesquisa

Nome:

Empresa: 


\section{APÊNDICE C - PROTOCOLO DE PESQUISA}

\begin{tabular}{|c|c|c|c|c|}
\hline \multicolumn{5}{|c|}{ Método de Pesquisa: Qualitativa } \\
\hline \multicolumn{3}{|c|}{ Coleta de dados: Observação Estruturada } & \multicolumn{2}{|c|}{$\begin{array}{l}\text { Participante: Dirigente da } \\
\text { empresa }\end{array}$} \\
\hline \multicolumn{5}{|c|}{$\begin{array}{l}\text { Objetivo Geral: avaliar as coerências e divergências entre a explicação da natureza do trabalho do } \\
\text { dirigente da pequena empresa e as teorizações existentes na literatura administrativa. }\end{array}$} \\
\hline $\begin{array}{c}\text { Objetivos } \\
\text { Específicos } \\
\end{array}$ & $\begin{array}{c}\text { Variáveis de } \\
\text { Pesquisa }\end{array}$ & $\begin{array}{l}\text { Questões de } \\
\text { Pesquisa }\end{array}$ & Constructo & $\begin{array}{c}\text { Formulário } \\
\text { de Coleta }\end{array}$ \\
\hline \multirow{4}{*}{$\begin{array}{l}\text { 1. } \\
\text { Verificar as } \\
\text { características do } \\
\text { trabalho do } \\
\text { dirigente da } \\
\text { pequena empresa } \\
\text { segundo quatro } \\
\text { dimensões: tipo de } \\
\text { atividade, lugar, } \\
\text { participantes e } \\
\text { iniciativas de } \\
\text { contato. }\end{array}$} & \multirow[t]{4}{*}{$\begin{array}{l}\text { 1.1 Características } \\
\text { do trabalho }\end{array}$} & \multirow{4}{*}{$\begin{array}{l}\text { 1.1.1 } \\
\text { Quais são as } \\
\text { características do } \\
\text { trabalho do } \\
\text { dirigente da } \\
\text { pequena empresa? }\end{array}$} & $\begin{array}{l}\text { 1.1.1.1 } \\
\text { Tipo de atividade }\end{array}$ & \\
\hline & & & $\begin{array}{c}\text { 1.1.1.2 } \\
\text { Lugar }\end{array}$ & \\
\hline & & & $\begin{array}{l}\text { 1.1.1.3 } \\
\text { Participantes }\end{array}$ & \\
\hline & & & $\begin{array}{l}\text { 1.1.1.4 Iniciativas } \\
\text { de contato }\end{array}$ & \\
\hline
\end{tabular}




\section{APÊNDICE C - PROTOCOLO DE PESQUISA (cont.)}

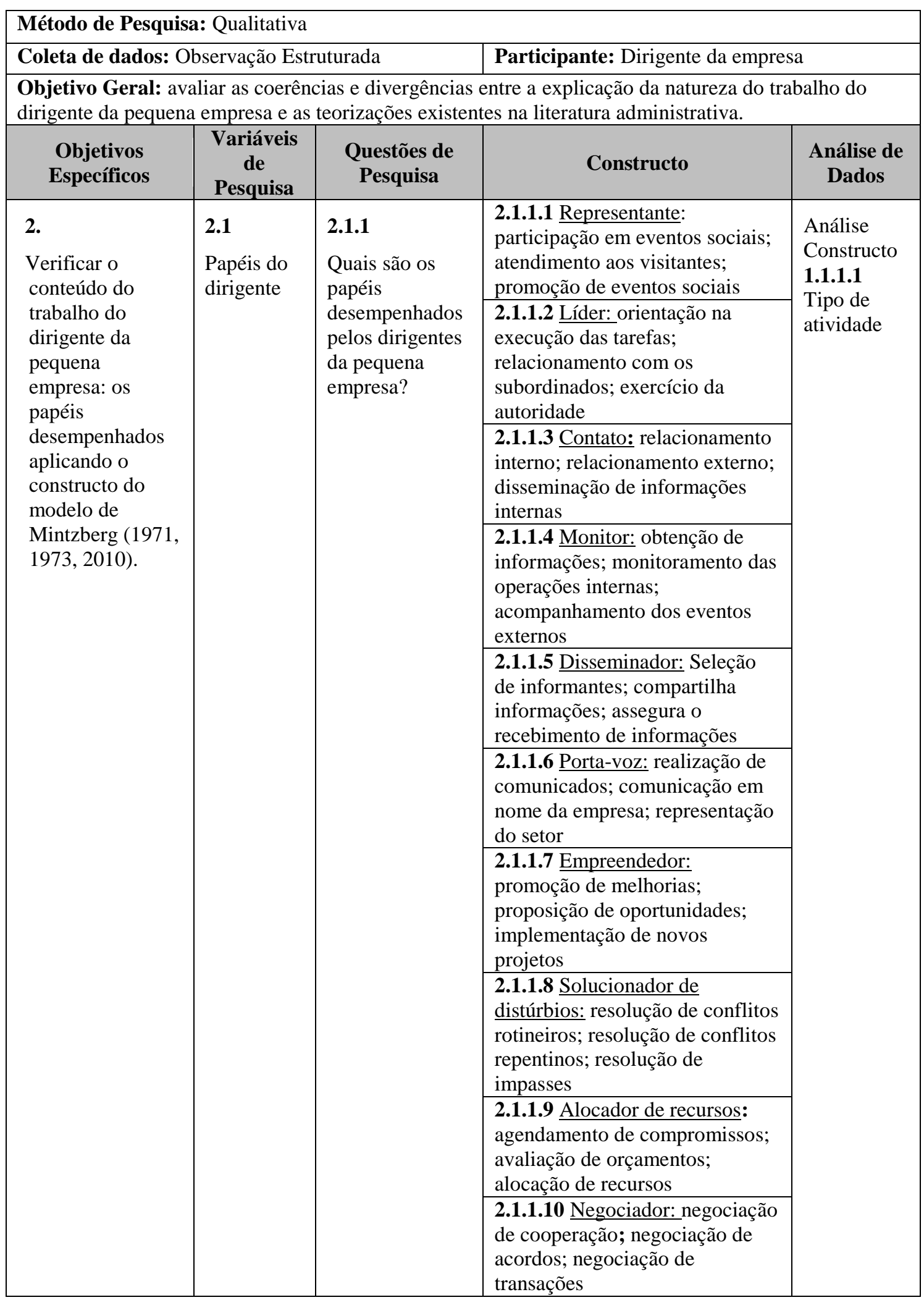




\section{APÊNDICE C - PROTOCOLO DE PESQUISA (cont.)}

\begin{tabular}{|c|c|c|c|c|}
\hline \multicolumn{5}{|c|}{ Método de Pesquisa: Qualitativa } \\
\hline \multicolumn{3}{|c|}{ Coleta de dados: Observação Estruturada } & \multicolumn{2}{|c|}{ Participante: Dirigente da empresa } \\
\hline \multicolumn{5}{|c|}{$\begin{array}{l}\text { Objetivo Geral: avaliar as coerências e divergências entre a explicação da natureza do trabalho do } \\
\text { dirigente da pequena empresa e as teorizações existentes na literatura administrativa. }\end{array}$} \\
\hline $\begin{array}{c}\text { Objetivos } \\
\text { Específicos }\end{array}$ & $\begin{array}{l}\text { Variáveis de } \\
\text { Pesquisa }\end{array}$ & $\begin{array}{l}\text { Questões de } \\
\text { Pesquisa }\end{array}$ & Constructo & Análise de Dados \\
\hline \multirow{8}{*}{$\begin{array}{l}\text { 3. } \\
\text { Identificar as } \\
\text { semelhanças e } \\
\text { diferenças nas } \\
\text { características } \\
\text { e papéis entre } \\
\text { os casos } \\
\text { múltiplos } \\
\text { estudados: } \\
\text { análise cruzada } \\
\text { de casos. }\end{array}$} & \multirow[t]{4}{*}{$\begin{array}{l}\text { 3.1 Semelhanças } \\
\text { entre os casos }\end{array}$} & \multirow{4}{*}{$\begin{array}{l}\text { 3.1.1 } \\
\text { Existem } \\
\text { semelhanças nas } \\
\text { características do } \\
\text { trabalho do } \\
\text { dirigente entre os } \\
\text { casos? }\end{array}$} & $\begin{array}{l}\text { 3.1.1.1 } \\
\text { Tipo de atividade }\end{array}$ & $\begin{array}{l}\text { Análise } \\
\text { Constructo 1.1.1.1 } \\
\text { Tipo de atividade }\end{array}$ \\
\hline & & & $\begin{array}{c}\text { 3.1.1.2 } \\
\text { Lugar }\end{array}$ & $\begin{array}{l}\text { Análise } \\
\text { Constructo 1.1.1.2 } \\
\text { Lugar }\end{array}$ \\
\hline & & & $\begin{array}{l}\text { 3.1.1.3 } \\
\text { Participantes }\end{array}$ & $\begin{array}{l}\text { Análise } \\
\text { Constructo 1.1.1.3 } \\
\text { Participantes }\end{array}$ \\
\hline & & & $\begin{array}{l}\text { 3.1.1.4 Iniciativas } \\
\text { de contato }\end{array}$ & $\begin{array}{l}\text { Análise } \\
\text { Constructo 1.1.1.4 } \\
\text { Iniciativa de } \\
\text { contato }\end{array}$ \\
\hline & \multirow[t]{4}{*}{$\begin{array}{l}\text { 3.2 } \\
\text { Diferenças entre } \\
\text { os casos }\end{array}$} & \multirow{4}{*}{$\begin{array}{l}\text { 3.2.1 } \\
\text { Existem diferenças } \\
\text { nas características } \\
\text { do trabalho do } \\
\text { dirigente entre os } \\
\text { casos? }\end{array}$} & $\begin{array}{l}\text { 3.2.1.1 } \\
\text { Tipo de atividade }\end{array}$ & $\begin{array}{l}\text { Análise } \\
\text { Constructo 1.1.1.1 } \\
\text { Tipo de atividade }\end{array}$ \\
\hline & & & $\begin{array}{l}\text { 3.2.1.2 } \\
\text { Lugar }\end{array}$ & $\begin{array}{l}\text { Análise } \\
\text { Constructo 1.1.1.2 } \\
\text { Lugar }\end{array}$ \\
\hline & & & $\begin{array}{l}\text { 3.2.1.3 } \\
\text { Participantes }\end{array}$ & $\begin{array}{l}\text { Análise } \\
\text { Constructo 1.1.1.3 } \\
\text { Participantes }\end{array}$ \\
\hline & & & $\begin{array}{l}\text { 3.2.1.4 Iniciativas } \\
\text { de contato }\end{array}$ & $\begin{array}{l}\text { Análise } \\
\text { Constructo 1.1.1.4 } \\
\text { Iniciativa de } \\
\text { contato }\end{array}$ \\
\hline
\end{tabular}




\section{APÊNDICE C - PROTOCOLO DE PESQUISA (cont.)}

\begin{tabular}{|c|c|c|c|c|}
\hline \multicolumn{5}{|c|}{ Método de Pesquisa: Qualitativa } \\
\hline \multicolumn{3}{|c|}{ Coleta de dados: Observação Estruturada } & \multicolumn{2}{|c|}{$\begin{array}{l}\text { Participante: Dirigente da } \\
\text { empresa }\end{array}$} \\
\hline \multicolumn{5}{|c|}{$\begin{array}{l}\text { Objetivo Geral: avaliar as coerências e divergências entre a explicação da natureza do trabalho do } \\
\text { dirigente da pequena empresa e as teorizações existentes na literatura administrativa. }\end{array}$} \\
\hline $\begin{array}{l}\text { Objetivos } \\
\text { Específicos }\end{array}$ & $\begin{array}{l}\text { Variáveis de } \\
\text { Pesquisa }\end{array}$ & $\begin{array}{l}\text { Questões de } \\
\text { Pesquisa }\end{array}$ & Constructo & $\begin{array}{l}\text { Análise de } \\
\text { Dados }\end{array}$ \\
\hline \multirow{3}{*}{$\begin{array}{l}\mathbf{4 .} \\
\text { Interpretar as } \\
\text { possíveis } \\
\text { diferenças entre as } \\
\text { características do } \\
\text { trabalho dos } \\
\text { dirigentes } \\
\text { aplicando a } \\
\text { estrutura teórica o } \\
\text { modelo das } \\
\text { demandas, } \\
\text { restrições e } \\
\text { escolhas de } \\
\text { Stewart (1982, } \\
\text { 1998, 2008). }\end{array}$} & \multirow[t]{3}{*}{$\begin{array}{l}\text { 4.1 } \\
\text { Características } \\
\text { do trabalho dos } \\
\text { dirigentes }\end{array}$} & \multirow{3}{*}{$\begin{array}{l}\text { 4.1.1 } \\
\text { O que explica as } \\
\text { possíveis } \\
\text { diferenças nas } \\
\text { características do } \\
\text { trabalho entre os } \\
\text { dirigentes? }\end{array}$} & $\begin{array}{l}\text { 4.1.1.1 } \\
\text { Demandas: } \\
\text { atividades que devem } \\
\text { ser cumpridas. }\end{array}$ & \multirow[t]{3}{*}{$\begin{array}{l}\text { Análise } \\
\text { Constructo } \\
\text { 1.1.1.1 Tipo } \\
\text { de atividade }\end{array}$} \\
\hline & & & $\begin{array}{l}\text { 4.1.1.2 } \\
\text { Restrições: } \\
\text { fatores, internos ou } \\
\text { externos, tangíveis } \\
\text { ou não, que limitam } \\
\text { o trabalho. } \\
\end{array}$ & \\
\hline & & & $\begin{array}{l}\text { 4.1.1.3 } \\
\text { Escolhas: atividades } \\
\text { que o ocupante do } \\
\text { cargo pode executar, } \\
\text { mas não é obrigado a } \\
\text { fazê-lo. }\end{array}$ & \\
\hline
\end{tabular}




\section{APÊNDICE D - INSTRUMENTO DE COLETA DE DADOS}

\begin{tabular}{|c|c|c|c|c|c|c|c|}
\hline \multicolumn{2}{|c|}{ (Nome Empresa) } & \multicolumn{4}{|c|}{ Nome Dirigente } & \multicolumn{2}{|l|}{ DATA: } \\
\hline № & ATIVIDADE & INí́cIO & DURAÇÃo & TIPO & LUGAR & PARTICIPANTES & $\begin{array}{l}\text { INICIATIVA } \\
\text { CONTATO }\end{array}$ \\
\hline \multicolumn{8}{|l|}{1} \\
\hline \multicolumn{8}{|l|}{2} \\
\hline \multicolumn{8}{|l|}{3} \\
\hline \multicolumn{8}{|l|}{4} \\
\hline \multicolumn{8}{|l|}{5} \\
\hline \multicolumn{8}{|l|}{6} \\
\hline \multicolumn{8}{|l|}{7} \\
\hline \multicolumn{8}{|l|}{8} \\
\hline \multicolumn{8}{|l|}{9} \\
\hline \multicolumn{8}{|l|}{10} \\
\hline \multicolumn{8}{|c|}{ Fim expediente da manhã } \\
\hline \multicolumn{8}{|l|}{1} \\
\hline \multicolumn{8}{|l|}{2} \\
\hline \multicolumn{8}{|l|}{3} \\
\hline \multicolumn{8}{|l|}{4} \\
\hline \multicolumn{8}{|l|}{5} \\
\hline \multicolumn{8}{|l|}{6} \\
\hline \multicolumn{8}{|l|}{7} \\
\hline \multicolumn{8}{|l|}{8} \\
\hline \multicolumn{8}{|l|}{9} \\
\hline 10 & & & & & & & \\
\hline & & & Fim expe & te da ta & & & \\
\hline
\end{tabular}

\begin{tabular}{|l|}
\hline Anotações complementares do pesquisador: \\
\hline $1-$ \\
\hline $2-$ \\
\hline $3-$ \\
\hline $4-$ \\
\hline $5-$ \\
\hline $6-$ \\
\hline $7-$ \\
\hline $8-$ \\
\hline $9-$ \\
\hline $10-$ \\
\hline
\end{tabular}


APÊNDICE D - INSTRUMENTO DE COLETA DE DADOS (cont.)

\begin{tabular}{|c|c|c|c|c|c|}
\hline & DIA 1 & DIA 2 & DIA 3 & DIA 4 & DIA 5 \\
\hline Ligações telefônicas & 0 & 0 & 0 & 0 & 0 \\
\hline \multicolumn{6}{|l|}{ Recebidas internas } \\
\hline \multicolumn{6}{|l|}{ Recebidas Externas } \\
\hline \multicolumn{6}{|l|}{ Realizadas Internas } \\
\hline \multicolumn{6}{|l|}{ Realizadas Externas } \\
\hline Contatos Pessoais & 0 & 0 & 0 & 0 & 0 \\
\hline \multicolumn{6}{|l|}{ Internos } \\
\hline \multicolumn{6}{|l|}{ Externos } \\
\hline E-mails recebidos & 0 & 0 & 0 & 0 & 0 \\
\hline \multicolumn{6}{|l|}{ Fornecedores } \\
\hline \multicolumn{6}{|l|}{ Clientes } \\
\hline \multicolumn{6}{|l|}{ Funcionários } \\
\hline \multicolumn{6}{|l|}{ Outros } \\
\hline E-mails enviados & 0 & 0 & 0 & 0 & 0 \\
\hline \multicolumn{6}{|l|}{ Fornecedores } \\
\hline \multicolumn{6}{|l|}{ Clientes } \\
\hline \multicolumn{6}{|l|}{ Funcionários } \\
\hline Outros & & & & & \\
\hline
\end{tabular}

\begin{tabular}{|l|}
\hline Anotações complementares do pesquisador: \\
\hline 1 - \\
\hline $2-$ \\
\hline $3-$ \\
\hline $4-$ \\
\hline $5-$ \\
\hline $6-$ \\
\hline $7-$ \\
\hline $8-$ \\
\hline $9-$ \\
\hline $10-$ \\
\hline
\end{tabular}


APÊNDICE E - LAYOUT PLANILHA EXCEL

\begin{tabular}{|c|c|c|c|c|c|c|c|c|}
\hline \multicolumn{2}{|r|}{ (Nome Empresa) } & \multicolumn{5}{|c|}{ Nome Dirigente } & \multicolumn{2}{|l|}{ DATA: } \\
\hline № & ATIVIDADE & INÍCIO & FIM & DURAÇÃO & TIPO & LUGAR & PARTICIPANTES & $\begin{array}{c}\text { INICIATIVA } \\
\text { CONTATO }\end{array}$ \\
\hline \multicolumn{9}{|l|}{1} \\
\hline \multicolumn{9}{|l|}{2} \\
\hline \multicolumn{9}{|l|}{3} \\
\hline \multicolumn{9}{|l|}{4} \\
\hline \multicolumn{9}{|l|}{5} \\
\hline \multicolumn{9}{|l|}{6} \\
\hline \multicolumn{9}{|l|}{7} \\
\hline \multicolumn{9}{|l|}{8} \\
\hline \multicolumn{9}{|l|}{9} \\
\hline \multicolumn{9}{|l|}{10} \\
\hline \multicolumn{9}{|c|}{ Fim expediente da manhã } \\
\hline \multicolumn{9}{|l|}{1} \\
\hline \multicolumn{9}{|l|}{2} \\
\hline \multicolumn{9}{|l|}{3} \\
\hline \multicolumn{9}{|l|}{4} \\
\hline \multicolumn{9}{|l|}{5} \\
\hline \multicolumn{9}{|l|}{6} \\
\hline \multicolumn{9}{|l|}{7} \\
\hline \multicolumn{9}{|l|}{8} \\
\hline \multicolumn{9}{|l|}{9} \\
\hline \multicolumn{9}{|l|}{10} \\
\hline \multicolumn{9}{|c|}{ Fim expediente da tarde } \\
\hline \multirow[t]{5}{*}{20} & $<=$ Total Atividades & Total & po $\Rightarrow$ & 00:00:00 & & & & \\
\hline & & & & Período & № Atividades & horas & minutos & minutos/atividade \\
\hline & & & & manhã & & & & \#DIV/0! \\
\hline & & & & tarde & & & & \#DIV/O! \\
\hline & & & & Total & 0 & 0:00:00 & - & \#DIV/0! \\
\hline
\end{tabular}


APÊNDICE E - LAYOUT PLANILHA EXCEL (cont.)

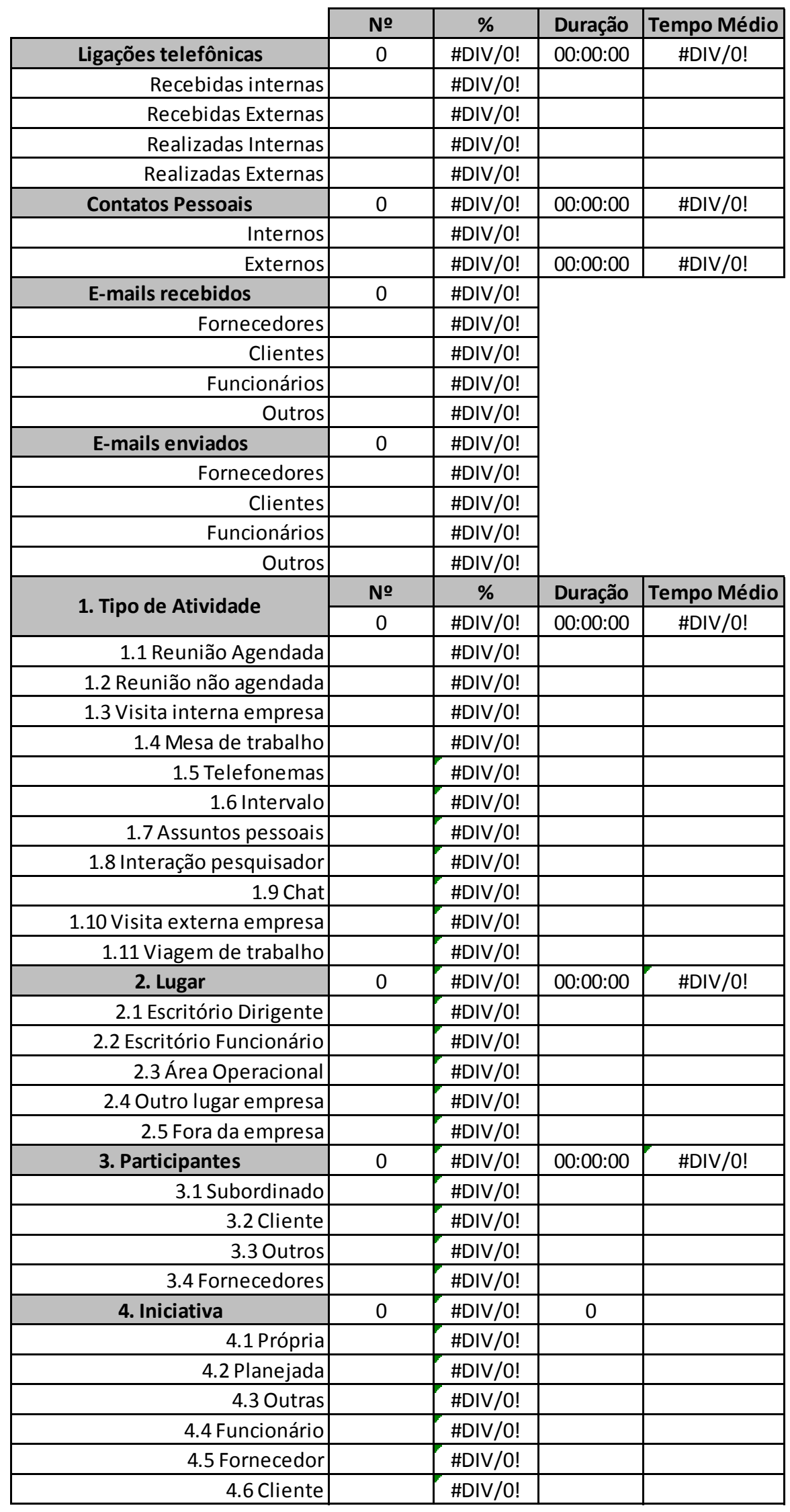




\section{APÊNDICE F - CRONOLOGIA ATIVIDADES DIRIGENTE}

\begin{tabular}{|c|c|c|c|c|c|c|c|c|c|c|c|c|c|c|c|c|c|}
\hline & \multicolumn{6}{|c|}{ DIRIGENTE EMPRESA Z } & \multicolumn{6}{|c|}{ DIRIGENTE EMPRESA T } & \multicolumn{5}{|c|}{ TOTAL } \\
\hline & \begin{tabular}{|c|} 
QTDE \\
TOTAL \\
\end{tabular} & $\%$ & Duração & \begin{tabular}{|l|} 
Tempo \\
Médio \\
\end{tabular} & $\%$ tempo & \begin{tabular}{|c|} 
QTDE/ \\
dia
\end{tabular} & \begin{tabular}{|l|} 
QTDE \\
TOTAL \\
\end{tabular} & $\%$ & Duração & $\begin{array}{l}\text { Tempo } \\
\text { Médio }\end{array}$ & $\%$ tempo & QTDE/dia & \begin{tabular}{|l|} 
QTDE \\
TOTAL \\
\end{tabular} & $\%$ & Duração & \begin{tabular}{|l|} 
Tempo \\
Médio \\
\end{tabular} & $\%$ tempo \\
\hline 1. Tipo de Atividade & 0 & $0 \%$ & 0:00:00 & \#DIV/0! & $0 \%$ & 0 & 0 & $0 \%$ & 0:00:00 & \#DIV/0! & $0 \%$ & 0 & 0 & $0 \%$ & 0:00:00 & \#DIV/0! & $0 \%$ \\
\hline 1.1 Reunião Agendada & & & & & & 0 & & & & & & 0 & 0 & & & & \\
\hline 1.2 Reunião não agendada & & & & & & 0 & & & & & & 0 & 0 & & & & \\
\hline 1.3 Visita interna empresa & & & & & & 0 & & & & & & 0 & 0 & & & & \\
\hline 1.4 Mesa de trabalho & & & & & & 0 & & & & & & 0 & 0 & & & & \\
\hline 1.5 Telefonemas & & & & & & 0 & & & & & & 0 & 0 & & & & \\
\hline 1.6 Intervalo & & & & & & 0 & & & & & & 0 & 0 & & & & \\
\hline 1.7 Assuntos pessoais & & & & & & 0 & & & & & & 0 & 0 & & & & \\
\hline 1.8 Interação pesquisador & & & & & & 0 & & & & & & 0 & 0 & & & & \\
\hline 1.9 Chat & & & & & & 0 & & & & & & 0 & 0 & & & & \\
\hline 1.10 Visita externa empresa & & & & & & 0 & & & & & & 0 & 0 & & & & \\
\hline 1.11 Viagem de trabalho & & & & & & 0 & & & & & & 0 & 0 & & & & \\
\hline 2. Lugar & 0 & $0 \%$ & 0:00:00 & \#DIV/0! & $0 \%$ & 0 & 0 & $0 \%$ & 0:00:00 & \#DIV/0! & $0 \%$ & 0 & 0 & $0 \%$ & 0:00:00 & \#DIV/0! & $0 \%$ \\
\hline 2.1 Escritório Dirigente & & & & & & 0 & & & & & & 0 & 0 & & & & \\
\hline 2.2 Escritório Subordinado & & & & & & 0 & & & & & & 0 & 0 & & & & \\
\hline 2.3 Área Operacional & & & & & & 0 & & & & & & 0 & 0 & & & & \\
\hline 2.4 Outro lugar empresa & & & & & & 0 & & & & & & 0 & 0 & & & & \\
\hline 2.5 Fora da empresa & & & & & & 0 & & & & & & 0 & 0 & & & & \\
\hline 3. Participantes & 0 & $0 \%$ & 0:00:00 & \#DIV/0! & $0 \%$ & 0 & 0 & $0 \%$ & 0:00:00 & \#DIV/0! & $0 \%$ & 0 & 0 & $0 \%$ & 0:00:00 & \#DIV/0! & $0 \%$ \\
\hline 3.1 Subordinados & & & & & & 0 & & & & & & 0 & 0 & & & & \\
\hline 3.2 Cliente & & & & & & 0 & & & & & & 0 & 0 & & & & \\
\hline 3.3 Outros & & & & & & 0 & & & & & & 0 & 0 & & & & \\
\hline 3.4 Fornecedores & & & & & & 0 & & & & & & 0 & 0 & & & & \\
\hline 4. Iniciativa & 0 & $0 \%$ & & & & 0 & 0 & $0 \%$ & & & & 0 & 0 & $0 \%$ & 0 & & \\
\hline 4.1 Própria & & & & & & 0 & & & & & & 0 & 0 & & & & \\
\hline 4.2 Planejada & & & & & & 0 & & & & & & 0 & 0 & & & & \\
\hline 4.3 Outras & & & & & & 0 & & & & & & 0 & 0 & & & & \\
\hline 4.4 Subordinados & & & & & & 0 & & & & & & 0 & 0 & & & & \\
\hline 4.5 Fornecedor & & & & & & 0 & & & & & & 0 & 0 & & & & \\
\hline 4.6 Cliente & & & & & & 0 & & & & & & 0 & 0 & & & & \\
\hline
\end{tabular}


APÊNDICE G - CONTATOS PESSOAIS DIRIGENTE

\begin{tabular}{|c|c|c|c|c|c|c|c|c|c|c|c|c|c|c|}
\hline & \multicolumn{5}{|c|}{ DIRIGENTE EMPRESA Z } & \multicolumn{5}{|c|}{ DIRIGENTE EMPRESA T } & \multicolumn{4}{|c|}{ Total } \\
\hline & \begin{tabular}{|c|} 
QTDE \\
TOTAL \\
\end{tabular} & $\%$ & Duração & $\begin{array}{l}\text { Tempo } \\
\text { Médio }\end{array}$ & $\begin{array}{c}\text { QTDE/ } \\
\text { dia }\end{array}$ & \begin{tabular}{|c|} 
QTDE \\
TOTAL
\end{tabular} & $\%$ & Duração & $\begin{array}{l}\text { Tempo } \\
\text { Médio }\end{array}$ & $\begin{array}{l}\text { QTDE/ } \\
\text { dia }\end{array}$ & $\begin{array}{l}\text { QTDE } \\
\text { TOTAL }\end{array}$ & $\%$ & Duração & $\begin{array}{l}\text { Tempo } \\
\text { Médio }\end{array}$ \\
\hline Ligações telefônicas & 0 & $0 \%$ & 00:00:00 & \#DIV/0! & 0 & 0 & $0 \%$ & 00:00:00 & \#DIV/0! & 0 & 0 & $0 \%$ & 00:00:00 & \#DIV/0! \\
\hline Recebidas internas & & & & & 0 & & & & & 0 & 0 & & & \\
\hline Recebidas Externas & & & & & 0 & & & & & 0 & 0 & & & \\
\hline Realizadas Internas & & & & & 0 & & & & & 0 & 0 & & & \\
\hline Realizadas Externas & & & & & 0 & & & & & 0 & 0 & & & \\
\hline Contatos Pessoais & 0 & $0 \%$ & 00:00:00 & \#DIV/0! & 0 & 0 & $0 \%$ & 00:00:00 & \#DIV/0! & 0 & 0 & $0 \%$ & 00:00:00 & \#DIV/0! \\
\hline Internos & & & & & 0 & & & & & 0 & 0 & & & \\
\hline Externos & & & & & 0 & & & & & 0 & 0 & & & \\
\hline E-mails recebidos & 0 & $0 \%$ & & & 0 & 0 & $0 \%$ & & & 0 & 0 & $0 \%$ & & \\
\hline Fornecedores & & & & & 0 & & & & & 0 & 0 & & & \\
\hline Clientes & & & & & 0 & & & & & 0 & 0 & & & \\
\hline Funcionários & & & & & 0 & & & & & 0 & 0 & & & \\
\hline Outros & & & & & 0 & & & & & 0 & 0 & & & \\
\hline E-mails enviados & 0 & $0 \%$ & & & 0 & 0 & & & & 0 & 0 & $0 \%$ & & \\
\hline Fornecedores & & & & & 0 & & & & & 0 & 0 & & & \\
\hline Clientes & & & & & 0 & & & & & 0 & 0 & & & \\
\hline Funcionários & & & & & 0 & & & & & 0 & 0 & & & \\
\hline Outros & & & & & 0 & & & & & 0 & 0 & & & \\
\hline
\end{tabular}




\title{
APÊNDICE H - OFÍCIO AGRADECIMENTO DIRIGENTE
}

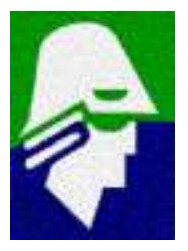

\section{UNIVERSIDADE DE SÃO PAULO \\ ESCOLA DE ENGENHARIA DE SÃO CARLOS DEPARTAMENTO DE ENGENHARIA DE PRODUÇÃO}

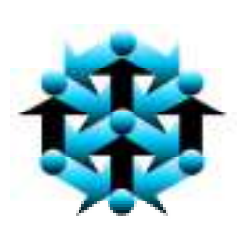

São Carlos, de de 20

\begin{abstract}
Sr. (Nome Dirigente)
Proprietário-Diretor

(Nome Empresa).
\end{abstract}

Prezado Sr. (Nome Dirigente),

Venho agradecer vossa gentileza na permissão e colaboração para que o pesquisador e mestrando (Nome mestrando) realizasse pesquisa de campo com coleta de dados em vossa empresa.

Já tenho retorno preliminar das atividades realizadas e sei que foi um sucesso graças a vossa pronta, cordial e facilitadora intervenção. Sou muito grato a essa especial colaboração com a pesquisa acadêmica.

Somos um Grupo de Pesquisa científica em administração, especialmente na gestão de pequenas empresas e espero em breve encontrá-lo em um dos nossos seminários de apresentação de resultados.

A produção científica encontra-se disponível na página do GEOPE - Grupo de Estudos Organizacionais da Pequena Empresa, da EESC - Escola de Engenharia de São Carlos, da USP - Universidade de São Paulo http://www.prod.eesc.usp.br/geope

Sendo o que tinha para tratar, agradeço mais uma vez vossa valiosa colaboração e deixo um forte abraço.

Cordialmente,

Edmundo Escrivão Filho

Professor Associado Coordenador do GEOPE Departamento de Engenharia de Produção - EESC/USP edesfi@sc.usp.br 


\title{
APÊNDICE I - OFÍCIO AGRADECIMENTO COORDENADOR ACADÊMICO
}

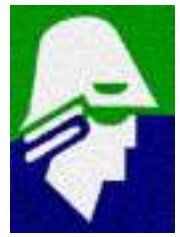

\author{
UNIVERSIDADE DE SÃO PAULO \\ ESCOLA DE ENGENHARIA DE SÃO CARLOS \\ DEPARTAMENTO DE ENGENHARIA DE PRODUÇÃO
}

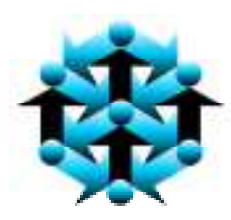

São Carlos, de de 20

Prof. (Nome Coordenador)

Coordenador

Curso de (Nome Curso)

(Nome Instituição Ensino Superior)

Prezado Prof. (Nome Coordenador),

Venho agradecer vossa gentileza na permissão e colaboração para que o pesquisador e mestrando (Nome mestrando) realizasse pesquisa de campo com coleta de dados na semana de de de 20

Já tenho retorno preliminar das atividades realizadas e sei que foi um sucesso. Sou muito grato a vossa especial colaboração com a pesquisa acadêmica.

Somos um Grupo de Pesquisa científica em administração, especialmente na gestão de pequenas empresas. A produção científica encontra-se disponível na página do GEOPE Grupo de Estudos Organizacionais da Pequena Empresa, da EESC - Escola de Engenharia de São Carlos, da USP - Universidade de São Paulo http://www.prod.eesc.usp.br/geope

Sendo o que tinha para tratar, agradeço mais uma vez vossa valiosa colaboração e deixo um forte abraço.

Cordialmente,

Edmundo Escrivão Filho

Professor Associado

Coordenador do GEOPE

Departamento de Engenharia de Produção - EESC/USP 